\title{
Essays on the Vietnam Stock Market
}

by

Phuong Thi Ly Nguyen

\author{
A thesis \\ Submitted to the Victoria University of Wellington \\ in fulfilment of the requirements for the degree of \\ Doctor of Philosophy \\ in Finance
}

Victoria University of Wellington

2020 

To my beloved family 



\section{Acknowledgements}

I would like to convey my sincere gratitude to my primary supervisor, Professor Hai Lin. I wish to thank Hai for accepting me as his student when I applied for a PhD at Victoria University of Wellington years ago. I thank Hai for his endless support and guidance during my $\mathrm{PhD}$ studies. He understood me and understood my English during my first days in Wellington. He guided me in improving presentation, modeling, and researching skills. He patiently corrected my first poor work until I produced a polished one. It would not have been possible for me to complete this research work without his dedicated, invaluable time. I am very lucky to be one of his students.

I also would like to express my gratitude to my secondary supervisor, Griffin Heng Geng, for sharing his expertise in econometrics and methodologies. His suggestions regarding researching methods and his feedback on my writing are valuable to me.

I also must thank all my amazing friends and fellow $\mathrm{PhD}$ students who supported and encouraged me throughout this journey. A special thanks to my best friends, Chung, Amy, Ilkin, and Steve, for being around when I needed a friend. Many thanks to all Vietnamese friends, Huyen, Binh, Hien, Quy, Cuong, Vu, and Thoa, for supporting my PhD life.

Sincere appreciation to the administrative staff at the School of Economics and Finance. Support from the library staff is also acknowledged. 


\section{Abstract}

This thesis consists of three substantive studies about the Vietnam stock market. In particular, I study the asymmetric information, corporate governance (CG) practices, and foreign investment of publicly listed companies in Vietnam, presented in Chapters 2, 3, and 4, respectively.

In Chapter 2, I investigate the effectiveness of a market surveillance system (MSS) on improving the market quality of the Vietnam stock market, as measured by liquidity and informed trading level. I find that market liquidity decreased after the introduction of the MSS, and that the effect is more pronounced for small firms. Although informed trading, on average, does not change significantly after the MSS, subsample analysis indicates a significant decrease in informed trading among large and liquid firms.

In Chapter 3, I investigate the relationship between firms' CG practices and informed trading. I find a negative relationship between the two variables. Firms with better CG practices have a lower level of informed stock trading. Moreover, a natural experiment on a shock of firms' CG practices generated by the CG policies shows that the negative relationship between $\mathrm{CG}$ practices and informed trading is a causal one, in which a change in the former causes a change in the latter. In another analysis around the implementation of the MSS, I find that the implementation of the surveillance system affects the relationship between the two variables, and this effect is driven by large and liquid firms.

In Chapter 4, I investigate whether foreign investors in the Vietnam stock market are informed about firms' performance. Using the residuals of foreign investor ownership as a measure of the abnormal foreign investor holding, I find that the abnormal foreign investor holding is positively correlated with firm performance in the following one year. I also find a positive correlation between abnormal foreign investor holding and the stock returns in the next three quarters. These findings indicate that foreign investors are informed about the firms up to a one-year period. 


\section{Contents}

1 Preliminaries 1

1.1 The Vietnam stock market $\ldots \ldots \ldots \ldots \ldots \ldots$

1.2 Studies on the Vietnam stock market . . . . . . . . . . . . . . . . 4

2 Liquidity, Informed Trading, and a Market Surveillance System: Evidence from $\begin{array}{lr}\text { the Vietnam Stock Market } & 6\end{array}$

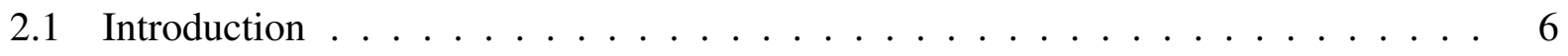

2.2 Market quality measures $\ldots \ldots \ldots \ldots \ldots \ldots$

2.2 .1 Liquidity measures $\ldots \ldots \ldots \ldots \ldots \ldots \ldots$

2.2.2 Informed trading measures $\ldots \ldots \ldots \ldots \ldots \ldots$

2.3 Data and Empirical Results . . . . . . . . . . . . . . . . . . . 16

2.3.1 Historical background and data . . . . . . . . . . . . 16

2.3.2 The market quality measures around the MSS: Full sample analysis _ . . 19

2.3.3 Firm characteristics and impact heterogeneity . . . . . . . . . . . 21

2.4 Discussion on other confounding events $\ldots \ldots \ldots \ldots \ldots \ldots \ldots$

2.5 Robustness tests . . . . . . . . . . . . . . . . . . . . 34

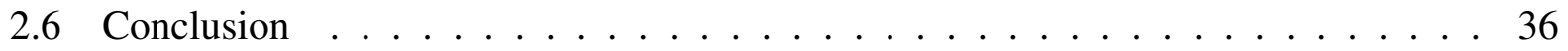

3 Corporate Governance and Informed Trading in the Vietnam Stock Market 38

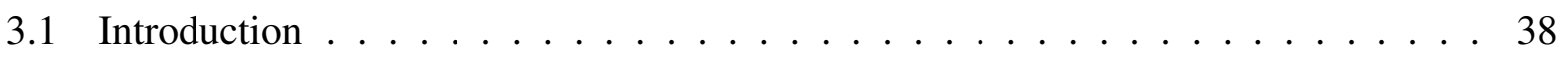

3.2 Variable construction and methodology . . . . . . . . . . . . . . 42

3.2 .1 Information asymmetry cost $(\mathrm{IAC}) \ldots \ldots \ldots \ldots \ldots \ldots$ 
3.2.2 Corporate governance score . . . . . . . . . . . . . . . . . . 44

3.2.3 Firm characteristics and other variables $\ldots \ldots \ldots$. . . . . . . . . 48

3.2.4 Regression with the Fama-MacBeth procedure . . . . . . . . . . . . . . . 49

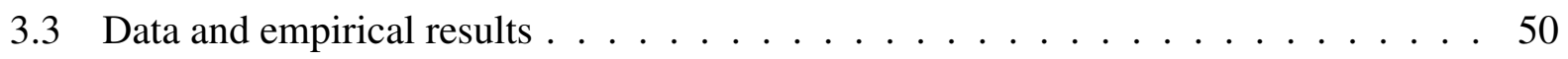

3.3 .1 Data . . . . . . . . . . . . . . . . . 50

$3.3 .2 \quad$ Empirical results $\ldots \ldots \ldots \ldots \ldots \ldots \ldots$

3.4 Corporate governance, informed trading, and the market surveillance system . . . . 59

3.5 Corporate governance and cumulative abnormal returns . . . . . . . . . . . . 61

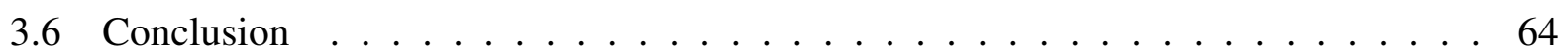

4 Are Foreign Investors Informed at the Vietnam Stock Market? 65

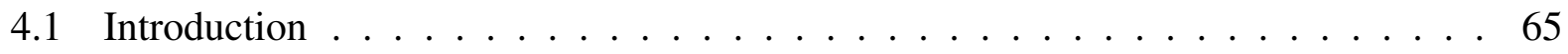

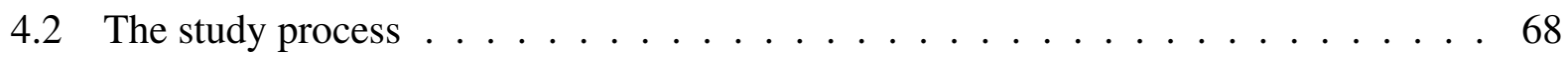

4.2 .1 The foreign ownership regression $\ldots \ldots \ldots \ldots$

4.2 .2 The main regression $\ldots \ldots \ldots \ldots \ldots$

4.3 Data and Empirical results $\ldots \ldots \ldots \ldots 71$

$4.3 .1 \quad$ Data . . . . . . . . . . . . . . . . 71

4.3.2 Abnormal foreign investor holding and firm performance . . . . . . . 73

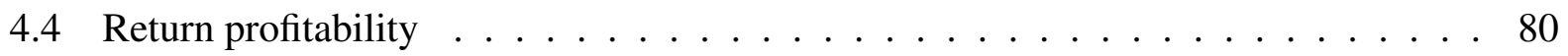

4.5 Changes of foreign ownership and firm performance . . . . . . . . . . 83

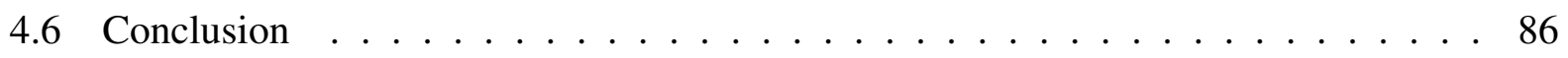

Appendices 


\section{List of Tables}

Table 2.1 Descriptive statistics . . . . . . . . . . . . . . . . . . . . . . . . . . . . . . 19

Table 2.2 Market liquidity measures . . . . . . . . . . . . . . . . . 20

Table 2.3 Parameter estimates of the MRR model . . . . . . . . . . . . . . . 22

Table 2.4 Liquidity and informed trading level for large and small firms . . . . . . . 23

Table 2.5 Liquidity and informed trading level for high and low trading frequency firms 25

Table 2.6 Liquidity and informed trading level for high and low turnover ratio firms . . 26

Table 2.7 Cross-sectional regression . . . . . . . . . . . . . . . . . . 31

Table 2.8 Regulation of the Vietnam stock market during 12/2011-03/2014 _ . . . . . 33

Table 2.9 Robustness test 1 : Using $20 \%$ and $80 \%$ percentile values $\ldots \ldots 35$

Table 2.10 Robustness test 2: Excluding three months before and after the MSS $\ldots \ldots 36$

Table 3.1 The corporate governance scorecard structure $\ldots \ldots$. . . . . . . . . . 48

Table 3.2 Descriptive statistics . . . . . . . . . . . . . . . . 51

Table 3.3 Correlation matrix $\ldots \ldots \ldots \ldots \ldots$

Table 3.4 Informed trading levels (IACs) of high- and low-CGS firms $\ldots \ldots$. . . . . 54

Table 3.5 Regression analysis $\ldots \ldots \ldots \ldots$. . . . . . . . . . . 55

Table 3.6 CG practices and informed trading level after the CG policies in $2012 \ldots \ldots 57$

Table 3.7 Corporate governance practice and informed trading before and after the MSS 61

Table 3.8 Cumulative abnormal returns (CAR) of high- and low-CGS firms around earnings announcements . . . . . . . . . . . . . . 63

Table 4.1 Descriptive statistics . . . . . . . . . . . . . . . . . . 72

Table 4.2 Estimating the informed foreign ownership $\ldots \ldots \ldots \ldots$ 
Table 4.3 Correlation matrix $\ldots \ldots \ldots \ldots \ldots$

Table 4.4 Informed foreign ownership and firm performance $\ldots \ldots . \ldots 78$

Table 4.5 Informed foreign ownership and firm performance: Alternative outcomes . . . 79

Table 4.6 The subsample analysis . . . . . . . . . . . . . . . . . . . 81

Table 4.7 Informed foreign ownership and stock prices $\ldots \ldots \ldots 3$

Table 4.8 Foreign ownership and firm performance: Robustness test . . . . . . . . . 85

Table D.1 Corporate governance scorecard . . . . . . . . . . . . . . . II

Table D.2 Data collection . . . . . . . . . . . . . . . IV 


\section{List of Figures}

Figure 1.1 The total market size $\ldots \ldots \ldots \ldots \ldots$. . . . . . . . . . 2

Figure 1.2 The market features of HOSE and HNX $\ldots \ldots \ldots \ldots$

Figure 2.1 Liquidity and informed trading of top and bottom groups over time . . . . . 29

Figure 3.1 The means of CGSs of benchmark groups of firms over time $\ldots \ldots \ldots 58$

Figure 4.1 The histogram of foreign ownership . . . . . . . . . . . . . . . . 74

Figure 4.2 The plots of abnormal foreign investment versus firm performance $\ldots$. . . 77 



\section{Chapter 1}

\section{Preliminaries}

\subsection{The Vietnam stock market}

The Vietnam stock market (VNX) has come to the attention of international markets in recent years. The Vietnamese indices are being watched at MSCI (a provider of critical decision-support tools and services for the global investment community) and FTSE Russell (a British provider of stock market indices and associated data services, wholly owned by the London Stock Exchange and operating from premises in Canary Wharf). FTSE recently put the Vietnam market on the watch list for possible reclassification to a second-tier emerging market.

About 20 years ago, in 1998, the Vietnamese government decided to set up two securities trading centers in Ho Chi Minh City and Hanoi, respectively. The Ho Chi Minh City Securities Trading Center officially executed its first trading session on July 28, 2000, with two stock codes listed. The trading center is an administrative agency of the State Securities Commission. In 2007, the trading center was renamed and upgraded to Ho Chi Minh Stock Exchange (HOSE). HOSE functions as the secondary market for public listed stocks and a number of existing bond issues.

The second trading center, the Hanoi Securities Trading Center, was founded in 2005. After four years, the trading center was established as the Hanoi Stock Exchange (HNX), and is owned by a state-owned single-member limited liability company. HNX has organized share auctions, 
government bond bidding, and has operated markets including the listed stock market, the government bond market, the unlisted public company market (UPCoM), and the derivatives market.

The sizes of two trading centers have increased dramatically since 2005. In Figure1.1, I report the number of codes of stocks registered in the centers (bar chart) and the number of shares in the centers (dashed line) from 2000 to 2018. In 2006, there were about 200 codes listed in the whole market, with a total number of shares of 2.6 billion. Those numbers increased gradually to about 750 codes and more than 90 billion shares in 2018.

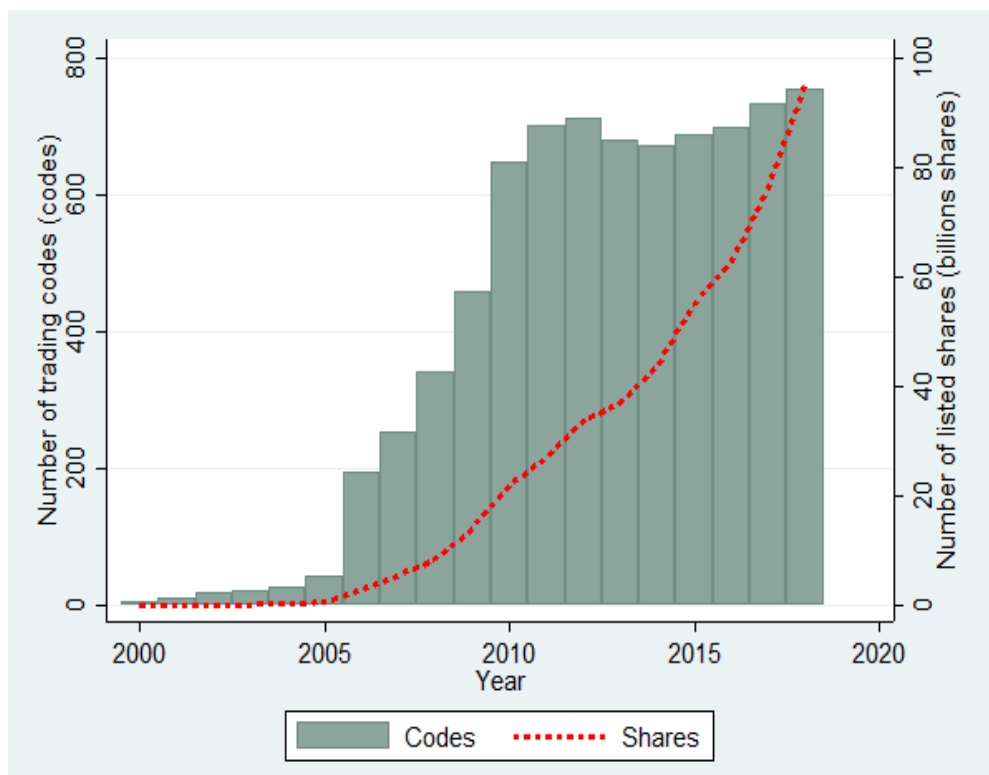

Figure 1.1. The total market size

This figure plots the number of codes of stocks (bar chart) and the number of shares (dashed line) registered in the centers from 2000 to 2018 . These numbers are the total from both HOSE and HNX each year. Data are collected from the HOSE and HNX websites.

The Vietnam stock market has grown over time. In the 19 years of its operation, its market capitalization, main indices (VNI, HNXI, and VNIAS), and foreign investment have increased remarkably, as shown in Figure 1.2.

Figure 1.2 reports the market features of HOSE and HNX, including the market capitalization, the buy and sell volume of foreign investors, and the main indices of HOSE and HNX over time. The left-top graph of Figure 1.2 reports the market capitalization. This variable is the average of 
the market capitalization of all firms listed at each exchange. While the market capitalization of HNX is stable over time, that of HOSE shoots up to 8 billion Vietnam dong (VND) in 2018, being twice of that in 2015. The Vietnam stock market, especially HOSE, has obviously grown quickly over the recent three years.

The right-top graph of Figure 1.2 reports the buy and sell volumes in VND of foreign investors in the Vietnam stock market. These volumes move together over time, but only those in HOSE have an increasing pattern. From 2014, the volumes in HOSE start to increase and have a clear upward trend from 2015. At the end of 2017, the volumes suddenly jump to a pick of over 50,000 billion VND. The numbers, after that, strongly fluctuate until the end of 2018. Meanwhile, the buy and sell volumes of foreign investors at HNX are stable around 0 up to the current time. It is worth noting that the government sets a limitation of foreign investment in the stock market. The limitation was $20 \%$ in 1999 (that means foreign investors could hold at most $20 \%$ of the total number of listed stocks of a publicly listed company), $30 \%$ in $2003,49 \%$ in 2009 , and is $100 \%$ from 2015. Some particular industries have this limitation at a lower level, though. ${ }^{1}$

The bottom graph of Figure 1.2 reports the main indices of the Vietnam stock market: VNI, HNXI, and VNIAS. The VNI is a capitalization-weighted price index of all the companies listed on HOSE. The index was created with a base index value of 100 as of July 28, 2000. The HNXI is a capitalization-weighted price index comprising stocks traded on the HNX. The VNIAS is defined by FTSE Russell, comprising companies within the top $90 \%$ of the eligible universe ranked by full market capitalization that meet the stated eligibility requirements of FTSE Russell (see the Ground Rules-FTSE Vietnam Index Series 2019). Obviously, the VNIAS moves with the VNI, and these two indices are far higher than the HNXI and were recorded at 1000 in 2018.

In short, since HOSE was established earlier, its market capitalization (size), foreign buy and sell volumes (trading activities), and index are all higher than those of HNX. HOSE is, therefore, the bigger and more active exchange.

\footnotetext{
${ }^{1}$ The limitations contained in the government's financial policies named: $139 / 1999 / Q D-T T g, 146 / 2003 / Q D-$ $T T g, 55 / 2009 / Q D-T T g$, and 60/2015/ND-CP.
} 

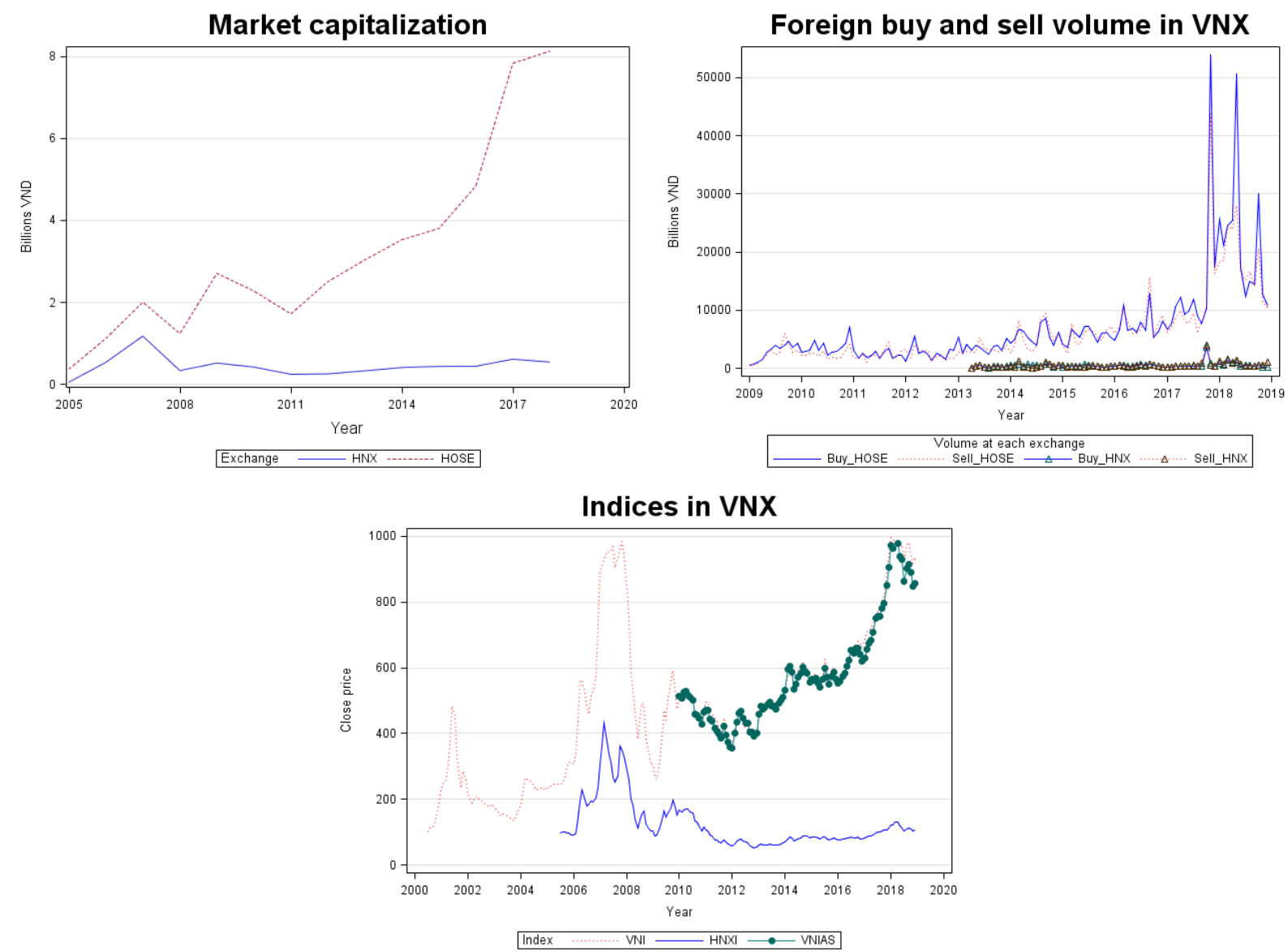

Figure 1.2. The market features of HOSE and HNX

This figure plots the market capitalization, the buy and sell volume of foreign investors, and the main indices (VNI, HNXI, and VNIAS) of HOSE, HNX, and the whole market over years. The market capitalization is the average of the market capitalization of all firms listed at each exchange. Buy and sell volume is displayed in VND. VNI is a capitalization-weighted price index of all the companies listed on the Ho Chi Minh City Stock Exchange. HNXI is a capitalization-weighted price index comprising stocks traded on the HNX. VNIAS is defined from FTSE Russell, comprising companies within the top $90 \%$ of the eligible universe ranked by full market capitalization that meet the stated eligibility requirements of FTSE. Data are collected from the HOSE and HNX websites and Thomson EIKON.

\subsection{Studies on the Vietnam stock market}

Since the Vietnam stock market is young, the literature on it is limited. Moreover, little research has been under taken on informed trading. Chang and $\mathrm{Su}$ (2010) examine the relationship between the Vietnam stock market and the United States, Japan, Singapore, and China stock markets. They find the Vietnam stock market was influenced by the news from the Japan and Singapore stock markets. Farber and Vuong (2004) use the method of cross-sectional standard deviation to find 
evidence of herd behavior in the Vietnam stock market. Loc, Lanjouw, and Lensink (2010) test the market efficiency of the Vietnam stock market. They used an autocorrelation test, a runs test, and a variance-ratio test and document that the Vietnam stock market was not efficient in weak-form.

As a result, I am encouraged to conduct studies on asymmetric information in the Vietnam stock market. In particular, I investigate whether the application of the market surveillance system (MSS) in 2013 helps reduce the asymmetric information. It is interesting to find that the MSS seems not to work effectively at least in the following one year of its implementation. One possible reason is that it takes longer than one year to generate a positive effect, which is out of the study period of Chapter 2.

I then study whether CG helps reduce the informed trading level. I address this question in the second study by regressing firms' CG scores on the informed trading level proxied by the information asymmetry cost. The results prove that an increase in the CG practices causes a decrease in informed trading.

I expand the studies about the Vietnam stock market by examining whether foreign investors in that market are informed about firms' performance. I find that the abnormal foreign investor holding is positively correlated with firms' future performance and the stock returns during the next four and three quarters, respectively, suggesting that foreign investor ownership is informed about firms up to a one-year period. 



\section{Chapter 2}

\section{Liquidity, Informed Trading, and a Market}

\section{Surveillance System: Evidence from the}

\section{Vietnam Stock Market}

\subsection{Introduction}

A growing body of evidence suggests that whether secondary stock market regulation is beneficial to market quality is an empirical question. Some studies report positive effects of these regulations. Bushman, Piotroski, and Smith (2005) find a more pronounced increase in analyst activity following restriction of insider trading activities in emerging markets. Ojah, Muhanji, and Kodongo (2020) document that effective insider trading law improves stock price informativeness in South Africa (and similarly in other emerging markets, including Chile, Indonesia, Malaysia, and Turkey). On the other hand, some policies have not worked effectively. For instance, the enactment of criminal sanctions for insider trading in New Zealand in 2008 led to a worsening in measures of the cost of trading, degree of information asymmetry, and the probability of informed trading (Frijns, Gilbert, and Tourani-Rad, 2013). Chung and Chuwonganant (2012) find that the quoted and effective spreads increased, the quoted depth decreased, and the market quality index 
decreased after the implementation of the Regulation National Market System (Reg NMS) in the US financial market. Bhattacharya, Daouk, Jorgenson, and Kehr (2000) and Cheuk, Fan, and So (2006) document that the regulations were ineffective to curb insider dealings in Mexico and Hong Kong, respectively. Budsaratragoon, Hillier, and Lhaopadchan (2012) show that the insider trading regulation in Thailand, which mimics developed market rules, fails on all three measures of success.

More importantly, many studies show the effectiveness of secondary market regulation, to a large extent, depends on a country's infrastructure and prior regulatory conditions. Not only are there differences between developed and emerging markets, but findings might vary from one emerging market to another (e.g., Fernandes and Ferreira, 2009; Budsaratragoon et al., 2012; Christensen, Hail, and Leuz, 2016; Chen, Huang, Kusnadi, and Wei, 2017; Aghanya, Agarwal, and Poshakwale, 2020). Different regulatory behavior, such as the introduction, implementation, and enforcement of the same regulation rules, might have different effects. See, for example, Bhattacharya and Daouk (2002), Aitken, Cumming, and Zhan (2015), and Bhattacharya and Daouk (2009). These findings highlight the need for a more detailed analysis of particular secondary market regulation.

In this study, I investigate this question by examining a market surveillance system (MSS) launched in the Vietnam stock market in 2013. As Cumming, Dannhauser, and Johan (2015) illustrate, surveillance in financial markets refers to computer algorithms directed at detecting insider trading and other forms of market manipulation, which allows the surveillance authorities to oversee trading activities more effectively and is an important component of regulation enforcement. In particular, this system (1) collects data from stock exchanges and the Vietnam Securities Depositary (VSD); (2) monitors all trading and provides alerts and reports in the event of various types of unusual activity, including abnormal price changes, changes in volume, and breaches of the trading rules; and (3) supports data retrieval for the sake of market surveillance. ${ }^{2}$ This MSS provides a setting to empirically examine the effect of strengthened secondary market regulation. A vital

\footnotetext{
${ }^{2}$ Source: State Securities Commission of Vietnam website.
} 
advantage of this setting is that it allows us to study this question in the context of an emerging market where market regulation is most needed.

As liquidity and informed trading level are two key measures of a stock market's quality and essential for a well-functioning stock market, ${ }^{3}$ I evaluate market quality through the changes of liquidity and informed trading level around the MSS event using a sample from March 2012 to March 2014. I measure the market liquidity using the bid-ask spread and other liquidity measures, such as the Amihud and Pastor-Stambaugh measure, and turnover ratio. Then, I use Madhavan, Richardson, and Roomans (1997) model (hereafter the MRR model) to estimate the information asymmetry level. ${ }^{4}$ I use this information asymmetry level as the measure of informed trading. I conduct $t$-tests and run difference-in-difference (DID) regressions to examine the changes of the liquidity and informed trading levels in a six-month and one-year window around the MSS event. I also run regressions to investigate the relationship between quality measure change and firm characteristics. I document several findings.

First, my empirical results show that the liquidity over 286 stocks at the Ho Chi Minh Exchange $(\mathrm{HOSE})^{5}$ becomes worse after the implementation of the MSS. Moreover, I find limited evidence showing that the MSS positively affects informed trading across the market.

Second, I analyze the impact of the MSS on firms with different characteristics. I consider size, trading frequency, and turnover ratio. I sort firms into terciles according to each firm characteristic separately, and test the difference in impact between the top and bottom groups using both $t$-test and DID regression. The firms in the bottom group are considered as control firms, while those firms in the top group are used as treatment firms. I find that the worsening effect of the MSS

\footnotetext{
${ }^{3}$ Liquidity reflects how quickly stock is traded without a significant impact on the price, while informed trading level measures the degree of information asymmetry among investors. Campbell, Lo, and MacKinlay (1997) show that informed trading measured by information asymmetry cost means that some investors are better informed about a security's value than the market makers. Informed trading is also likely to be driven by illegal insider information that is under strict regulation. See, for example, Meulbroek (1992), Bhattacharya and Daouk (2002), Acharya and Johnson (2007), and Ahern (2017).

${ }^{4}$ Madhavan et al. (1997) propose a model to decompose the bid-ask spread into liquidity and information asymmetry components.

${ }^{5}$ I choose stocks listed at HOSE as my sample because HOSE is a more active exchange than the Hanoi Stock Exchange (HNX) in the Vietnamese stock market. Data from Thompson Reuters show that the average number of transactions per day in HOSE from 2009 to 2013 is 11,108 trades, compared with 5,904 trades in HNX in the same period.
} 
on stock liquidity mainly happens for small, low trading frequency, and high turnover ratio firms. Meanwhile, the informed trading of large and high trading frequency firms improves after the implementation of the MSS. Both a $t$-test and DID regression show similar results. Aslan, Easley, Hvidkjaer, and O'Hara (2011) find that smaller, younger firms and firms followed by few analysts are more likely to have higher information risk. This finding means they are more likely to be targeted by the MSS to improve market quality. My finding that only the informed trading of large and liquid firms improves after the MSS suggests that the policy is not effective in regulating small and illiquid firms.

Third, I run cross-sectional regressions of the market quality measure change on selected firm characteristics variables. I find a negative relationship between firm size, trading frequency, and the change of liquidity measures. These results, along with the fact of the overall decline of market liquidity after the MSS implementation, suggest that the worsening effect of the MSS on liquidity is stronger for small and low trading frequency firms. I also document a negative relationship between firm size, trading frequency, and the information asymmetry measure. These results, along with the overall effect of no significant impact of the MSS on information asymmetry, show that large and high trading frequency firms tend to have an improved informed trading level on the Vietnamese stock market.

I also discuss the theoretical and policy implications of my main findings and investigate whether other events drive my results. I collected all the regulations, circulars, and policies related to the Vietnamese stock market between December 2011 and March 2014, and find no other policy is relevant to my findings. I finally run several robustness tests and find my results hold.

My study contributes to the literature in several ways. First, my work adds to the budding literature on the effectiveness of insider trading and market manipulation regulation in an emerging market. Since the financial market is in development and the market governance quality is still a big concern, there is a greater demand to explore the construction of sound regulatory regimes in emerging markets than in developed markets. Literature also shows that even emerging markets are not homogenous. My study provides detailed evidence on the effectiveness of regulation in the 
Vietnamese stock market. For such an emerging market that has been receiving increasing attention in recent years, this issue has not been explored yet. Chang and $\mathrm{Su}$ (2010) examine the relationship between the Vietnamese stock market and the US, Japanese, Singapore, and Chinese stock markets. They find the Vietnamese stock market was influenced by the news from the Japanese and Singapore stock markets. Farber and Vuong (2004) use the method of the cross-sectional standard deviation to find evidence of herd behavior in the Vietnamese stock market. Loc et al. (2010) test the market efficiency of the Vietnamese stock market. They used an autocorrelation test, runs test, and variance-ratio test and document that the Vietnamese stock market was not efficient in weakform. This paper fills the gap by studying the liquidity and informed trading of the Vietnamese stock market and how the implementation of the MSS affects them.

Second, I provide new and direct evidence on the impact of stock market surveillance. As one of the most fundamental components, surveillance performs a pivotal role in the whole regulatory framework (Domowitz, 2012). ${ }^{6}$ In exploring the effects of secondary market regulation, most of the literature has focused on the introduction and enforcement of regulations, while there is relatively little research examining the market surveillance, which might be due to the difficulty in obtaining the data. To the best of my knowledge, only a few papers have explored the effects of market surveillance. Using unique confidential surveillance data, Comerton-Forde and Rydge (2006) examine surveillance efforts at the Australian Stock Exchange and its impact on market integrity. Using survey data on surveillance characteristics from twenty-five exchanges, Cumming and Johan (2008) explore the relationship between market surveillance activities and market efficiency and trading activity proxied by trading velocity, listings, and market capitalization. They find that cross-market surveillance is more effective than single-market surveillance. Later, Cumming, Johan, and Li (2011) and Aitken et al. (2015) use the data from Cumming and Johan (2008) to examine the joint effect of detailed trading rules and surveillance. My paper provides new

\footnotetext{
${ }^{6}$ For example, in April 2005, the US SEC charged the NYSE with failing to police specialists. The SEC pointed out the NYSE surveillance efforts were inadequate in detecting, investigating, and disciplining specialist behavior. In settling this action, the NYSE consented to undertake several significant remedial measures, including enhancing its surveillance efforts. In March 2020, when the SEC approved rule change to facilitate NYSE electronic auctions in response to COVID-19, information about surveillance procedures associated with these modifications was required to be provided at the same time.
} 
evidence on the effectiveness of market surveillance.

My results also contribute to the literature by documenting the complications of financial market regulation in an emerging market. My research shows that, in the Vietnamese stock market, the MSS does not improve the aggregate market quality, but the policy effects differ across firms. On the whole, my findings are consistent with prior studies that document the difficulties of implementing and enforcing new rules in emerging market (e.g., Fernandes and Ferreira, 2009; Budsaratragoon et al., 2012; Christensen et al., 2016; Chen et al., 2017) and early work on the economics of regulation and the enforcement theory (e.g., Stigler, 1971; Posner, 1974; Becker, 1983; Djankov, Glaeser, La Porta, Lopez-de Silanes, and Shleifer, 2003). My findings demonstrate once again that secondary market regulation is a complicated issue. The mere introduction or enforcement of a single regulation rule can be unfruitful and it requires a series of complementary institutional and infrastructure reforms to make the regulation effective. Meanwhile, my study reveals that the effects of regulation are different not only among countries but also among firms. This highlights the need for more diversified regulatory rules and enforcement depending on firm characteristics.

The rest of the chapter is organized as follows. Section 2 describes the market quality measures used in the chapter. Section 3 describes the historical background and the data and reports the main empirical results. Section 4 tests if any other policy besides the MSS may have an impact on the market quality of the Vietnam stock market. I do a robustness check in Section 5. Section 6 concludes.

\subsection{Market quality measures}

\subsubsection{Liquidity measures}

I employ the liquidity measures that are widely used in the literature. The measures I use include bid-ask spread, the Amihud illiquidity measure, turnover ratio, and the Pastor and Stambaugh (2003) measure. 


\subsubsection{Bid-ask spread}

Bid-ask spread is widely used in the literature as a proxy of liquidity. For example, Chordia, Roll, and Subrahmanyam (2008) and Chung and Hrazdil (2010) use bid-ask spreads to investigate the relationship between liquidity and market efficiency. I consider two different types of bid-ask spread, including quoted bid-ask spread and effective bid-ask spread.

I first follow Lesmond (2005) to calculate the quoted bid-ask spread as the ratio of the difference between ask and bid prices on the midpoint of the quotes (midquote).

$$
Q S_{i, t}=\frac{A_{i, t}-B_{i, t}}{\text { Midquote }_{i, t}}
$$

where Midquote $e_{i, t}=\frac{A_{i, t}+B_{i, t}}{2}$, and $A_{i, t}\left(B_{i, t}\right)$ is the best quoted ask (bid) price for stock $i$ at time $t$.

I also calculate the effective bid-ask spread, which is designed to measure marketable orders executed in relation to the market center's quoted spread and takes into account hidden and midpoint liquidity available at each market center. The effective bid-ask spread is the absolute value of the difference between the actual trade price and the midpoint of the market quotes (bid and ask quotes), divided by the midpoint.

$$
E S_{i, t}=\frac{\mid P_{i, t}-\text { Midquot }_{i, t} \mid}{\text { Midquote }_{i, t}}
$$

where $P_{i, t}$ is the transaction price of stock $i$ at time $t$.

Both quoted spread and effective spread reveal the overall trading cost that the investors incur, although they have their own ways to process the bid and ask prices. A higher spread is associated with a lower degree of market quality. Therefore, I should expect a decrease in the spreads after the implementation of the MSS if the system is effective. 


\subsubsection{Amihud illiquidity measure}

The Amihud illiquidity measure is the daily ratio of absolute stock return to dollar volume (Amihud, 2002). For the Vietnam market, I use the Vietnam dong (VND) instead of the US dollar to compute the volume in currency. For each stock, I calculate the Amihud illiquidity using the average ratio of the daily absolute return to the VND trading volume on that day during a period. The formula for a stock's Amihud illiquidity is defined as follows:

$$
I L L I Q_{i y}=\frac{1}{D_{i y}} \sum_{t=1}^{D_{i y}} \frac{\left|r_{i y, t}\right|}{V O L D_{i y, t}},
$$

where $r_{i y, t}$ is the return on stock $i$ on day $t$ of period $y, V O L D_{i y, t}$ is the corresponding daily trading volume in VND, and $D_{i y}$ is the number of trading days for stock $i$ in period $y$.

\subsubsection{Turnover ratio}

Following Lesmond (2005), I calculate turnover ratio as follows:

$$
\text { Turnover }_{i y}=\frac{1}{D_{i y}} \sum_{t=1}^{D_{i y}} \frac{\text { Volume }_{i y, t}}{\text { Share }_{i y, t}}
$$

where Volume $_{i y, t}$ is the number of shares traded in stock $i$ on day $t$ of period $y$, and Share $_{i y, t}$ is the number of outstanding shares of stock $i$ on day $t$ of period $y$.

\subsubsection{Pastor-Stambaugh measure}

Following Pástor and Stambaugh (2003), I calculate the Pastor-Stambaugh liquidity measure for stock $i$ in period $y$ using the following regression:

$$
r_{i y, t+1}^{e}=\theta_{i y}+\phi_{i y} r_{i y, t}+\gamma_{i y} \operatorname{sign}\left(r_{i y, t}^{e}\right) V O L D_{i y, t}+\varepsilon_{i y, t+1}
$$

where $r_{i y, t}^{e}=r_{i y, t}-r_{m y, t}, \operatorname{sign}(x)$ is an indicator function that equals to 1 if $x$ is positive, -1 if $x$ is negative, and 0 otherwise. $r_{m y, t}$ is the market return on the same day. $\gamma_{i y}$ captures the reversal for a 
given volume (in VND) of stock $i$ in period $y$, and it is used to measure the illiquidity. Pástor and Stambaugh (2003) show that the greater the reversal for a given volume (a more negative value of $\left.\gamma_{i y}\right)$, the lower the stock's liquidity.

\subsubsection{Informed trading measures}

I use the information asymmetry level as the measure of informed trading on the Vietnam stock market. I estimate the information asymmetry level using the quasi-structural model of Madhavan et al. (1997) (the MRR model), which is one of the most widely used market microstructure models. ${ }^{7}$ The MRR model links the revision in belief to innovations in order flows and public information shocks. The following are a general description of the model and the estimated parameters used as the proxy of informed trading.

Let $\mu_{t}$ be the expected stock value at time $t$. The revision in belief of $\mu_{t}$ is the sum of order flow innovation and new public information which is random,

$$
\mu_{t}=\mu_{t-1}+\theta\left(x_{t}-\rho x_{t-1}\right)+\varepsilon_{t}
$$

In this equation, $\theta$ captures the impact of order flow innovation on the expected stock value and measures information asymmetry. $\rho$ is the first-order autocorrelation of order flow and $x_{t}-\rho x_{t-1}$ captures the order flow innovation. $x_{t}$ is an indicator variable for trade initiation. $x_{t}$ equals to 1 if the trade is buyer initiated, -1 if the trade is seller initiated, and 0 otherwise. Let $\lambda$ denote the unconditional probability that the transaction occurs within the quote spread, or $\lambda=\operatorname{Pr}\left[x_{t}=0\right]$, and assume that buys and sells are equally likely, then we have $E\left[x_{t}\right]=0$ and $\operatorname{var}\left[x_{t}\right]=(1-\lambda)$.

The transaction price $p_{t}$ could be written as the sum of expected stock value, liquidity cost and stochastic rounding errors,

$$
p_{t}=\mu_{t}+\phi x_{t}+\xi_{t}
$$

\footnotetext{
${ }^{7}$ Examples of using the MRR model include Frijns, Gilbert, and Tourani-Rad (2008); He, Lin, Wang, and Wu (2009a); He, Lin, Wu, and Dufrene (2009b); and Frijns et al. (2013).
} 
where $\phi$ captures the liquidity impact and measures liquidity cost. The change of transaction price is then

$$
\Delta p_{t} \equiv p_{t}-p_{t-1}=(\phi+\theta) x_{t}-(\phi+\rho \theta) x_{t-1}+\varepsilon_{t}+\xi_{t}-\xi_{t-1}
$$

Following Madhavan et al. (1997), I use generalized method of moments (GMM) to estimate the model. The moment conditions are

$$
E\left(\begin{array}{l}
x_{t} x_{t-1}-x_{t-1}^{2} \rho \\
\left|x_{t}\right|-(1-\lambda) \\
z_{t}-\alpha \\
\left(z_{t}-\alpha\right) x_{t} \\
\left(z_{t}-\alpha\right) x_{t-1}
\end{array}\right)=0
$$

where $z_{t}=\varepsilon_{t}+\xi_{t}-\xi_{t-1}$. The estimated parameters include $\theta$ (the information asymmetry), $\phi$ (the liquidity cost), $\lambda$ (the probability a transaction takes place inside the spread), and $\rho$ (the autocorrelation of the order flow).

While using $\theta$ as the main proxy for informed trading level in my study, I also calculate the proportion of the spread that is attributed to information asymmetry, $\pi$, as follows:

$$
\pi=\frac{\theta}{(\phi+\theta)}
$$

A decrease in this ratio means that the proportion of information asymmetry in the bid-ask spread becomes lower. It, thus, means a reduction of the probability of informed trading in the market. I use this as another measure of informed trading in addition to the information asymmetry level. 


\subsection{Data and Empirical Results}

\subsubsection{Historical background and data}

Vietnam stock market starts to operate since July 2000. The Ho Chi Minh City Securities Trading Center officially executed its first trading session on July 28, 2000, with two stock codes listed. In 2007, the trading center was renamed and upgraded to the Ho Chi Minh Stock Exchange (HOSE). The Vietnam stock market has grown over time. Its market capitalization, main indices (VNI, HNXI, and VNIAS), and foreign investment have increased remarkably in recent years and has come to the attention of international markets. For example, the Vietnamese stock market indices are being watched at MSCI (a provider of critical decision-support tools and services for the global investment community) and FTSE Russell (a British provider of stock market indices and associated data services, wholly owned by the London Stock Exchange and operated from premises in Canary Wharf). In June 2018, FTSE put the Vietnam market on the watch list for possible reclassification to a second-tier emerging market.

To ensure a fair playing field and encourage the stable and sustainable development of the Vietnam stock market, the Vietnam government has been introducing laws to regulate the secondary market since 2006. The Securities Laws No. 70/2006/QH11 10 dated 29 June 2006 (Security Laws 2006) was the first law to regulate participants and activities related to the stock market. It specifies that the Ministry of Finance (MOF) is responsible for conducting securities laws and regulations, while State Securities Committee (SSC) supervises financial institutions and market participants and is empowered to inspect, monitor, and execute violations in securities activities. The Security Laws 2006 prohibits the insiders from trading on private or price-sensitive information and providing such information to a third party, or making the trades through other individuals and organizations. Circular 2007, along with its amendments Circular 2010 and Circular 2012, also provides the regulations for insider trading disclosures.

The SSC has also been trying to regulate the market manipulation. In 2010, the Vietnam SSC prosecuted the nation's first share-price manipulation case, sending a clear message that any stock 
price manipulation will be punished strictly. The Criminal Code of 2015 considers secondary market manipulation as a crime if a person deliberately commits manipulating acts and earns a profit of from VND 500mil (US\$22,500) or causes a loss to investors of from VND 1bil. (US\$ $45,000)$.

To collect necessary data for overseeing trading activities and enforcing secondary market regulation, the SSC launched a market surveillance system (MSS) in the Vietnam stock market on 19 March 2013. This event marks a new development stage of transparency improvement at the Vietnam stock market by strengthening regulation and supervision capacity over trading activities. Before the MSS implementation, the surveillance duties, from detecting an abnormal transaction, analyzing it, to applying a punishment if applicable, were completely physical-based. The surveillance results, therefore, mostly depended on the supervisors' experience on the relevant laws and subjects. Thanks to the technical functions of the MSS described earlier, regulators can quickly collect information on daily transactions and correctly detect an abnormal transaction. This helps prevent not only the current insider trading problem but also the stock price manipulation and information disclosure violations. The percentage of administrative sanctions against violations related to abnormal trading increases from $28.37 \%$ during 2010-2012 to 43.85\% during 2014-2016 in the Vietnamese stock market. ${ }^{8}$

To study how the MSS affects the market quality, I collect a sample covering data of HOSE from 1 March 2012 to 31 March 2014. I include all stocks listed on the HOSE, but exclude the new firms which are listed on the exchange after the event. To study the event carefully, I examine two different windows around it. Specifically, I examine the liquidity and informed trading levels in the six-month or one-year periods before and after the MSS. Therefore, I split the sample into prechange and post-change samples using the cut-off point of 19 March 2013. To control the possible short-term impact of the MSS event, I also exclude the data for March 2013 in my analysis. For example, some market participants might anticipate the implementation of the MSS and react before the event. After the implementation, it might also take several days for the market to adopt

\footnotetext{
${ }^{8}$ Data source: the State Securities Commission of Vietnam.
} 
the new policy fully. To avoid possible anticipations which may add noises to the marker quality measures before the event, I delete data of days before the MSS date. Likewise, I leave days for the market to adopt a new event. These constraints, with the implementation date 19 March 2013, help us delete all data of March 2013 out of the sample.

I collect intraday information from the Thompson Reuters Tick History (TRTH) database available from SIRCA. The TRTH dataset provides limit order book and transaction information of all stocks on the HOSE during the sample period. I collect the number of outstanding shares, market capitalization, and price/earnings (PE) ratio of each firm from the Bloomberg terminal. I finally end with a sample of 286 stocks in total. However, I have only 282 shares in the pre-change period, since four firms were listed at HOSE less than six months before the event. I exclude these four firms when conducting the pair-matched $t$-test in my analysis.

I first clean the data by excluding the observations with bid quotes being greater than ask quotes, and replacing missing bid or ask quotes by the last available non-missing quotes. To determine the trade initiation direction, I follow Madhavan et al. (1997) and apply Lee and Ready (1991) using the order book and transaction information. Specifically, I use the tick test method to define trade initiation. A transaction is defined as a buyer initiation ( $x_{t}$ equals to 1 ) if the transaction price is higher than the previous price, or as a seller initiation ( $x_{t}$ equal to -1$)$ if the transaction price is lower than the last price. A trade initiation is zero when its transaction price equals to the midpoint of the bid-ask spread.

Table 2.1 reports the summary statistics of the data sample used in my analysis. I report the average stock price, average trading frequency per day, average volume per transaction, and the standard deviation of daily returns. For the whole sample, the number of trades per day averages at 54.66 deals, suggesting that the Vietnam stock market is still a thin-trading market. ${ }^{9}$

I also observe an increase in trading activity after the implementation of the MSS. Most of trading frequency measures (average trades per day and average volume per trade) increase after the launch of the system both in the six-month and one-year windows. For instance, the average

\footnotetext{
${ }^{9}$ Madhavan et al. (1997) report the number of 95 daily transactions on the NYSE.
} 
Table 2.1. Descriptive statistics

This table presents the statistics of the full sample and the one-year and six-month windows around the market surveillance system (MSS) implemented in the Vietnam stock market on 19 March 2013. The Full sample contains data of all companies in my sample from 1 March 2012 to 31 March 2014. Pre-change and post-change are the periods before and after the MSS event, respectively. I exclude the data for March 2013 when analyzing the two windows. Average price is the mean daily price of the stocks traded in the market. Average trades per day is the number of trades that occur in one trading day in each window. Volume per trade is the number of shares that are executed in one transaction. Finally, Volatility in daily return is the standard deviation of daily stock returns. The figures reported in this table are the cross-sectional summary statistics.

\begin{tabular}{lrrrrrr}
\hline & Full sample & \multicolumn{2}{r}{ One-year window } & & \multicolumn{2}{c}{ Six-month window } \\
\hline & & Pre-change & Post-change & & Pre-change & Post-change \\
\cline { 6 - 7 } Average price (VND) & 17,928 & 16,910 & 18,999 & & 16,098 & 18,140 \\
Mean & 17,662 & 15,887 & 19,924 & & 16,764 & 20,514 \\
Std Dev & 156,950 & 139,142 & 170,916 & & 157,021 & 197,680 \\
Max & 2,752 & 2,291 & 2,243 & & 2,326 & 1,708 \\
Min & & & & & & \\
Average trades per day (trades) & 54.66 & 48.54 & 61.32 & & 42.26 & 48.84 \\
Mean & 21.20 & 18.38 & 22.65 & & 16.29 & 11.18 \\
Std Dev & 152.44 & 105.52 & 152.44 & & 91.12 & 79.98 \\
Max & 20.92 & 20.92 & 29.62 & & 20.92 & 29.62 \\
Min & & & & & \\
Average volume per trade (shares) & 3,316 & 2,992 & 3,578 & & 3,011 & 4,001 \\
Mean & 4,008 & 2,876 & 6,853 & & 3,507 & 12,943 \\
Std Dev & 49,128 & 20,008 & 101,620 & & 28,290 & 199,067 \\
Max & 151 & 27 & 244 & & 12 & 199 \\
Min & & & & & \\
Volatility in daily return (\%) & 2.66 & 2.69 & 2.57 & & 2.54 & 2.57 \\
Mean & 0.62 & 0.58 & 0.85 & & 0.70 & 0.98 \\
Std Dev & 4.68 & 5.62 & 5.57 & & 5.67 & 5.61 \\
Max & 1.29 & 1.52 & 0.94 & & 1.12 & 0.55 \\
Min & & &
\end{tabular}

trades per day increase from 42.26 to 48.84 in the six-month window, and rise from 48.54 to 61.32 in the one-year window. This result shows that the Vietnam stock market becomes more active after the MSS event. Meanwhile, the standard deviation of daily returns shows a limited difference before and after the MSS implementation.

\subsubsection{The market quality measures around the MSS: Full sample analysis}

In this section, I investigate whether the MSS helps to improve the liquidity and reduce the informed trading level using the whole data sample. This analysis provides an overall evaluation of the MSS's effectiveness.

Table 2.2 reports the results of liquidity measures before and after the MSS implementation. I 
report the means of liquidity measures before and after the event and the differences between these two periods. The last column indicates the $p$-value of the pair-matched $t$-test for the difference. At first sight, I find that the bid-ask spreads on the Vietnam stock market are much higher than those on the US market reported in Chung and Chuwonganant (2012), which reflects the high transaction cost of an emerging market.

Table 2.2. Market liquidity measures

This table reports the means of liquidity measures. The calculations of these measures are explained in Section 2.2. I report the cross-sectional mean of each measure during different periods. Pre-change and post-change are the periods before and after the MSS event, respectively. I apply pair-matched $t$-test to test the significance of the mean differences. I use a sample of 282 companies in the $t$-test.

\begin{tabular}{|c|c|c|c|c|}
\hline \multirow[b]{3}{*}{ Six-month window } & \multicolumn{3}{|c|}{ Mean } & \multirow{2}{*}{$\begin{array}{c}\text { p-value } \\
\text { pair-matched } \\
t \text {-test } \\
\end{array}$} \\
\hline & $\begin{array}{c}\text { Pre-change } \\
(1)\end{array}$ & $\begin{array}{c}\text { Post-change } \\
\text { (2) }\end{array}$ & $\begin{array}{c}\text { Difference } \\
(2-1)\end{array}$ & \\
\hline & & & & \\
\hline Turnover ratio $(\%)$ & 0.28 & 0.38 & 0.10 & 0.46 \\
\hline Amihud illiquidity measure $\left(\times 10^{-2}\right)$ & 2.31 & 2.57 & 0.26 & 0.36 \\
\hline Quote spread (\%) & 2.45 & 2.63 & 0.18 & 0.00 \\
\hline Effective spread (\%) & 1.21 & 1.29 & 0.08 & 0.00 \\
\hline Pastor-Stambaugh measure $\left(\times 10^{-7}\right)$ & 4.50 & 0.74 & -3.76 & 0.14 \\
\hline \multicolumn{5}{|l|}{ One-year window } \\
\hline Turnover ratio $(\%)$ & 0.33 & 0.49 & 0.16 & 0.05 \\
\hline Amihud illiquidity measure $\left(\times 10^{-2}\right)$ & 1.59 & 1.91 & 0.32 & 0.17 \\
\hline Quote spread (\%) & 2.24 & 2.42 & 0.18 & 0.00 \\
\hline Effective spread (\%) & 1.11 & 1.18 & 0.07 & 0.00 \\
\hline Pastor-Stambaugh measure $\left(\times 10^{-7}\right)$ & 1.62 & 0.37 & -1.25 & 0.13 \\
\hline \multicolumn{5}{|l|}{ Whole sample } \\
\hline & Mean & Std dev & Maximum & Minimum \\
\hline Turnover ratio $(\%)$ & 0.50 & 1.51 & 22.14 & 0.01 \\
\hline Amihud illiquidity measure $\left(\times 10^{-2}\right)$ & 1.74 & 3.98 & 37.68 & 0.00 \\
\hline Quote spread (\%) & 2.33 & 1.20 & 5.57 & 0.29 \\
\hline Effective spread $(\%)$ & 1.14 & 0.58 & 2.81 & 0.17 \\
\hline Pastor-Stambaugh measure $\left(\times 10^{-7}\right)$ & 0.40 & 0.98 & 9.85 & 0.00 \\
\hline
\end{tabular}

I find a significant increase in bid-ask spreads after the MSS event. In the six-month window, the quoted spread changes from $2.45 \%$ to $2.63 \%$. The difference is $0.18 \%$ and significant at the $1 \%$ level. The effective spread increases by $0.08 \%$, which is also significant at the $1 \%$ level. The results of the one-year window are similar. These findings imply that the Vietnam stock market becomes less liquid after the MSS implementation.

I then use the MRR model to estimate the information asymmetry level for each firm in each window and report the results in Table 2.3. In Table 2.3, I report the cross-sectional mean of 
information asymmetry level $\theta$, order-processing and inventory $\operatorname{cost} \phi$ (liquidity cost), probability of trade within the quotes $\lambda$, first-autocorrelation in order flow $\rho$, and proportion of information asymmetry in the bid-ask spread $\pi$. I focus on information asymmetry $\theta$ and the proportion of information asymmetry $\pi$. They are used as the measures of informed trading level in my study.

In Table 2.3, I find there is no significant change in the informed trading level after the MSS. In the one-year window, the mean $\theta$ s before and after the MSS are 0.3635 and 0.3443 respectively, giving a difference of -0.0192 with a $p$-value of 0.19 . Only $\pi$ significantly decreases in the one-year window. Overall, I fail to find consistent evidence that the informed trading level of the Vietnam stock market is reduced after the MSS event.

The full sample analysis shows that the market liquidity on the HOSE becomes worse after the MSS implementation. Moreover, there is no clear evidence to state that the informed trading level is reduced. I then turn to subsample analysis to investigate whether the impact of MSS is different among the firms with different characteristics.

\subsubsection{Firm characteristics and impact heterogeneity}

\subsubsection{Univariate analysis}

So far, I observe a decline of the market quality after the introduction of the MSS. An issue of interest is whether the impact depends on firm characteristics. To address this issue, I consider three firm characteristics and examine how they influence the effects of MSS on market quality. I use firm size, trading frequency, and turnover ratio. I first run a univariate analysis to sort the firms into three groups according to the $33 \%$ and $66 \%$ percentile values of each characteristic variable during the pre-change period. ${ }^{10}$ I test whether the change of quality measures around the event is significantly different between firms in the top and bottom group.

Then I use DID regression to test if the changes in the liquidity and informed trading measures of the top group are significantly different from those changes of the bottom group. In the regression, the firms in the top group are used as treatment firms, while the firms in the bottom group are

\footnotetext{
${ }^{10}$ In the robustness check, I also use $20 \%$ and $80 \%$ percentile values.
} 
Table 2.3. Parameter estimates of the MRR model

This table reports the summary statistics of the parameter estimates in equation (2.8) for the full sample in both one-year and six-month windows. Mean is the simple average of the parameters of the stocks in the full sample in each window. I also reports the standard deviation (Std.dev), and the median of each parameter. Full sample contains data of all companies in my sample from 1st March 2012 to 31st March 2014. All data for March 2013 are excluded from the estimation in the two windows. Pre-change and post-change are the periods before and after the MSS event, respectively. The difference in the means between the post-change and pre-change periods are tested by pair-matched $t$-test. ${ }^{* * *},{ }^{* *}$, and ${ }^{*}$ indicate significance at the $1 \%, 5 \%$, and $10 \%$ level, respectively.

\begin{tabular}{|c|c|c|c|c|c|c|c|}
\hline & \multirow[t]{2}{*}{ Full sample } & \multicolumn{3}{|c|}{ One-year window } & \multicolumn{3}{|c|}{ Six-month window } \\
\hline & & $\begin{array}{c}\text { Pre-change } \\
\text { (1) }\end{array}$ & $\begin{array}{c}\text { Post-change } \\
\text { (2) }\end{array}$ & $\begin{array}{c}\text { Difference } \\
(2-1)\end{array}$ & $\begin{array}{c}\text { Pre-change } \\
\text { (4) }\end{array}$ & $\begin{array}{c}\text { Post-change } \\
\text { (5) }\end{array}$ & $\begin{array}{c}\text { Difference } \\
(5-4)\end{array}$ \\
\hline \multicolumn{8}{|c|}{ Information asymmetry $(\theta)$} \\
\hline Mean & 0.3271 & 0.3635 & 0.3443 & \multirow[t]{3}{*}{-0.0192} & 0.4211 & 0.4390 & \multirow[t]{3}{*}{0.0179} \\
\hline Std.dev & 0.2784 & 0.2943 & 0.3423 & & 0.5123 & 0.5744 & \\
\hline Median & 0.2772 & 0.2006 & 0.2445 & & 0.3083 & 0.2855 & \\
\hline \multicolumn{8}{|c|}{ Order-processing and inventory costs $(\phi)$} \\
\hline Mean & 0.5141 & 0.5261 & 0.5379 & \multirow[t]{3}{*}{0.0118} & 0.5905 & 0.6277 & \multirow[t]{3}{*}{0.0372} \\
\hline Std.dev & 0.3290 & 0.3198 & 0.3964 & & 0.4602 & 0.5611 & \\
\hline Median & 0.4457 & 0.2187 & 0.4148 & & 0.5519 & 0.5143 & \\
\hline \multicolumn{8}{|c|}{ Probability of trade within the quotes $(\lambda)$} \\
\hline Mean & 0.1064 & 0.1360 & 0.0872 & \multirow[t]{3}{*}{$-0.0488^{* * *}$} & 0.1311 & 0.1028 & \multirow[t]{3}{*}{$-0.0283^{* * *}$} \\
\hline Std.dev & 0.0628 & 0.0690 & 0.0715 & & 0.0821 & 0.0938 & \\
\hline Median & 0.0961 & 0.0934 & 0.0857 & & 0.1101 & 0.0867 & \\
\hline \multicolumn{8}{|c|}{ First-order autocorrelation in order flow $(\rho)$} \\
\hline Mean & 0.1930 & 0.1904 & 0.1825 & \multirow[t]{3}{*}{$-0.0079^{*}$} & 0.1789 & 0.1606 & \multirow[t]{3}{*}{$-0.0183^{* * *}$} \\
\hline Std.dev & 0.1108 & 0.1052 & 0.1250 & & 0.1255 & 0.1320 & \\
\hline Median & 0.1737 & 0.1569 & 0.1436 & & 0.1682 & 0.1432 & \\
\hline \multicolumn{8}{|c|}{ Proportion of information asymmetry cost $(\pi)$} \\
\hline Mean & 0.3687 & 0.3982 & 0.3550 & \multirow[t]{3}{*}{$-0.0432^{* * *}$} & 0.3860 & 0.3714 & \multirow[t]{3}{*}{-0.0146} \\
\hline Std.dev & 0.1425 & 0.1433 & 0.1645 & & 0.1957 & 0.2347 & \\
\hline Median & 0.3939 & 0.4785 & 0.3709 & & 0.3882 & 0.3709 & \\
\hline
\end{tabular}

considered as control firms. The firms in the middle group are not used in the DID regression. The basic DID regression is written as

$$
Y_{i, t}=\beta_{0}+\beta_{1} \text { Time }_{i, t}+\beta_{2} \text { Group }_{i, t}+\beta_{3} \text { Time }_{i, t} \times \text { Group }_{i, t}+\varepsilon_{i, t},
$$

where $Y_{i, t}$ is the liquidity or information asymmetry measure that I consider. Time $e_{i, t}$ is a dummy variable which takes a value of 1 if the time is post-MSS or 0 otherwise, Group $p_{i, t}$ is another dummy variable which takes a value of 1 when the firm $i$ is in the top group or 0 otherwise.

$\beta_{3}$ in the equation measures the change of the liquidity or informed trading measures of the treatment (top) group around the MSS relative to that of the control (bottom) group. I run the regression for each liquidity or information asymmetry measure, and test whether the interaction 
coefficient $\beta_{3}$ is significantly different from 0 .

Table 2.4. Liquidity and informed trading level for large and small firms

This table reports the liquidity and informed trading measures for large and small firms around the MSS implementation. Large (small) firms are firms on the top (bottom) 33\% of the sample firms by their average market capitalization one year or six months before the MSS implementation. Panel A reports the means of liquidity or informed trading measures before (Pre-change) and after (Post-change) the MSS implementation, followed by the pair-match $t$-test for their difference. Panel B reports the coefficients of the DID regressions to test how the MSS differently impacts the change of these measures between large and small firms. The sample size is $282 .{ }^{* *},{ }^{* *}$, and ${ }^{*}$ indicate significance at the $1 \%, 5 \%$, and $10 \%$ level, respectively.

\begin{tabular}{|c|c|c|c|c|c|c|}
\hline \multicolumn{7}{|l|}{ Panel A. Sample results } \\
\hline & \multicolumn{3}{|c|}{ One-year window } & \multicolumn{3}{|c|}{ Six-month window } \\
\hline & $\begin{array}{l}\text { Pre-change } \\
\text { (1) }\end{array}$ & $\begin{array}{l}\text { Post-change } \\
\text { (2) }\end{array}$ & $\begin{array}{c}\text { Difference } \\
(2-1)\end{array}$ & $\begin{array}{l}\text { Pre-change } \\
\text { (4) }\end{array}$ & $\begin{array}{l}\text { Post-change } \\
\text { (5) }\end{array}$ & $\begin{array}{c}\text { Difference } \\
(5-4)\end{array}$ \\
\hline \multicolumn{7}{|l|}{ Large firms } \\
\hline (i) Turnover ratio (\%) & 0.25 & 0.52 & 0.27 & 0.19 & 0.58 & 0.39 \\
\hline (ii) Amihud illiquidity measure $\left(\times 10^{-2}\right)$ & 0.36 & 0.28 & -0.08 & 0.55 & 0.39 & $-0.16^{*}$ \\
\hline (iii) Quote spread (\%) & 1.61 & 1.57 & -0.04 & 1.82 & 1.75 & -0.07 \\
\hline (iv) Effective spread (\%) & 0.82 & 0.78 & -0.04 & 0.91 & 0.88 & -0.03 \\
\hline (v) Pastor-Stambaugh measure $\left(\times 10^{-7}\right)$ & 0.19 & 0.11 & $-0.08^{* * *}$ & 0.29 & 0.22 & -0.07 \\
\hline (vi) Information asymmetry cost IAC $(\theta)$ & 0.25 & 0.21 & $-0.04^{* * *}$ & 0.29 & 0.27 & -0.02 \\
\hline (vii) Proportion of IAC $(\pi)$ & 0.41 & 0.34 & $-0.07^{* * *}$ & 0.40 & 0.37 & $-0.03^{*}$ \\
\hline \multicolumn{7}{|l|}{ Small firms } \\
\hline (i) Turnover ratio (\%) & 0.33 & 0.38 & 0.05 & 0.24 & 0.20 & -0.04 \\
\hline (ii) Amihud illiquidity measure $\left(\times 10^{-2}\right)$ & 3.37 & 3.99 & 0.62 & 4.99 & 5.52 & 0.53 \\
\hline (iii) Quote spread (\%) & 2.75 & 3.21 & $0.46^{* * *}$ & 3.11 & 3.49 & $0.38^{* * *}$ \\
\hline (iv) Effective spread (\%) & 1.36 & 1.56 & $0.20^{* * *}$ & 1.53 & 1.71 & $0.18^{* * *}$ \\
\hline (v) Pastor-Stambaugh measure $\left(\times 10^{-7}\right)$ & 3.94 & 0.55 & -3.39 & 11.54 & 1.13 & -10.41 \\
\hline (vi) Information asymmetry cost IAC ( $\theta)$ & 0.47 & 0.46 & -0.01 & 0.60 & 0.67 & 0.08 \\
\hline (vii) Proportion of IAC $(\pi)$ & 0.39 & 0.37 & $-0.02^{*}$ & 0.38 & 0.39 & 0.01 \\
\hline
\end{tabular}

Panel B. DID regression $Y_{i, t}=\beta_{0}+\beta_{1}$ Time $_{i, t}+\beta_{2}$ Group $_{i, t}+\beta_{3}$ Time $_{i, t} *$ Group $_{i, t}+\varepsilon_{i, t}$

\begin{tabular}{|c|c|c|c|c|c|c|}
\hline & \multicolumn{3}{|c|}{ One-year window } & \multicolumn{3}{|c|}{ Six-month window } \\
\hline & $\overline{\beta_{1}}$ & $\beta_{2}$ & $\overline{\beta_{3}}$ & $\overline{\beta_{1}}$ & $\overline{\beta_{2}}$ & $\beta_{3}$ \\
\hline (i) Turnover ratio (\%) & 0.05 & -0.07 & 0.22 & -0.04 & -0.05 & 0.43 \\
\hline (ii) Amihud illiquidity measure $\left(\times 10^{-2}\right)$ & 0.62 & -3.01 & -0.71 & 0.53 & -4.44 & -0.70 \\
\hline (iii) Quote spread (\%) & 0.46 & -1.14 & $-0.50^{* *}$ & 0.38 & -1.29 & $-0.45^{*}$ \\
\hline (iv) Effective spread (\%) & 0.20 & -0.53 & $-0.25^{* *}$ & 0.18 & -0.62 & -0.21 \\
\hline (v) Pastor-Stambaugh measure $\left(\times 10^{-7}\right)$ & -3.39 & -3.74 & 3.31 & -10.41 & -11.25 & 10.34 \\
\hline (vi) Information asymmetry cost IAC $(\theta)$ & -0.01 & -0.22 & -0.04 & 0.08 & -0.31 & -0.10 \\
\hline (vii) Proportion of IAC $(\pi)$ & -0.02 & 0.02 & -0.05 & 0.01 & 0.01 & -0.03 \\
\hline
\end{tabular}

Table 2.4 reports the liquidity and information asymmetry measures of large and small firms around the MSS implementation. Firm size is measured by market capitalization. In Panel A, I report the mean of each quality measure. The left and right columns indicate the results of the one-year and six-month window, respectively. While there is some evidence that the liquidity of large firms improves after the MSS event, the liquidity of small firms become significantly worse. 
For instance, in the one-year window, the change of the Pastor-Stambaugh measure around the MSS event for large firms is $-0.08 \times 10^{-7}$ and significant at the $1 \%$ level. Meanwhile, the quoted spread and effective spread of small firms increase by $0.46 \%$ and $0.20 \%$, respectively, during the one-year window around the MSS event. The differences are significant at the $1 \%$ level.

I also observe a significant decrease in the information asymmetric measure for large firms. For example, $\theta$ and $\pi$ drop by 0.04 and 0.07 , respectively, during the one-year window. Both of these changes are significant at the $1 \%$ level. The impact of the MSS on the information asymmetry of small firms is much weaker. The results of the six-month window are weaker but similar. In summary, I find that the MSS event negatively affects the liquidity of small firms, but positively reduces the information asymmetry of large firms.

Panel B of Table 2.4 reports the results of DID regression for large and small firms. The variable of interest is $\beta_{3}$, which tests the difference of market quality measure change around the MSS event between large and small firms. The $\beta_{3}$ s of quoted spread and effective spread are -0.50 and -0.25 , respectively, during the one-year window and significant at the $5 \%$ level. These results suggest that the impact of the MSS event on the liquidity of large firms is significantly weaker than that of small firms, which is consistent with the results in Panel A.

Table 2.5 reports the results for firms with high and low trading frequency. Panel A reports the sample results, while panel B reports the DID regression results. The impact of the MSS event on the liquidity of firms with different trading frequency is inconclusive. For example, for the high trading frequency firms, the Pastor-Stambaugh measure drops by $-0.04 \times 10^{-7}$ in the one-year window, while the Amihud measure increases by 0.01. I also find mixed results for low trading frequency firms. Their quoted spread and effective spread increase by $0.34 \%$ and $0.12 \%$, respectively, during the one-year window, while their Pastor-Stambaugh measure drops by $-3.53 \times 10^{-7}$. These results also reflect that liquidity is hard to define, and a different liquidity measure captures a different aspect of liquidity.

On the other hand, I find that the level of informed trading of the high trading frequency firms becomes significantly smaller after the MSS event, but this tendency does not apply for low trading 
Table 2.5. Liquidity and informed trading level for high and low trading frequency firms

This table reports the liquidity and informed trading measures for high and low trading frequency firms around the MSS. High (low) trading frequency firms are firms on the top (bottom) 33\% of the sample firms by their average number of transactions executed per day in one year or six months before the MSS implementation. Panel A reports the means of liquidity or informed trading measures before (pre-change) and after (post-change) the MSS implementation, followed by the pair-match $t$-test for their difference. Panel B reports the coefficients of DID regressions to test how the MSS differently impacts the change of these measures between high and low trading frequency firms. The sample size is 282. ${ }^{* * *},{ }^{* *}$, and ${ }^{*}$ indicate significance at the $1 \%, 5 \%$, and $10 \%$ level, respectively.

\begin{tabular}{|c|c|c|c|c|c|c|}
\hline \multicolumn{7}{|l|}{ Panel A. Sample results } \\
\hline & \multicolumn{3}{|c|}{ One-year window } & \multicolumn{3}{|c|}{ Six-month window } \\
\hline & $\begin{array}{l}\text { Pre-change } \\
\text { (1) }\end{array}$ & $\begin{array}{l}\text { Post-change } \\
\text { (2) }\end{array}$ & $\begin{array}{l}\text { Difference } \\
(2-1)\end{array}$ & $\begin{array}{l}\text { Pre-change } \\
\text { (4) }\end{array}$ & $\begin{array}{l}\text { Post-change } \\
\quad \text { (5) }\end{array}$ & $\begin{array}{l}\text { Difference } \\
(5-4)\end{array}$ \\
\hline \multicolumn{7}{|l|}{ High trading frequency firms } \\
\hline (i) Turnover ratio (\%) & 0.69 & 0.97 & 0.28 & 0.64 & 0.90 & 0.26 \\
\hline (ii) Amihud illiquidity measure $\left(\times 10^{-2}\right)$ & 0.00 & 0.01 & $0.01^{* *}$ & 0.00 & 0.01 & 0.01 \\
\hline (iii) Quote spread (\%) & 1.61 & 1.23 & 0.07 & 1.22 & 1.31 & $0.09^{*}$ \\
\hline (iv) Effective spread (\%) & 0.62 & 0.64 & 0.02 & 0.64 & 0.70 & 0.06 \\
\hline (v) Pastor-Stambaugh measure $\left(\times 10^{-7}\right)$ & 0.10 & 0.06 & $-0.04^{* * *}$ & 0.08 & 0.08 & 0.00 \\
\hline (vi) Information asymmetry cost IAC $(\theta)$ & 0.12 & 0.08 & $-0.04^{* * *}$ & 0.12 & 0.14 & 0.02 \\
\hline (vii) Proportion of IAC $(\pi)$ & 0.33 & 0.23 & $-0.10^{* * *}$ & 0.31 & 0.26 & $-0.05^{* * *}$ \\
\hline \multicolumn{7}{|l|}{ Low trading frequency firms } \\
\hline (i) Turnover ratio (\%) & 0.07 & 0.12 & $0.05^{*}$ & 0.05 & 0.08 & 0.03 \\
\hline (ii) Amihud illiquidity measure $\left(\times 10^{-2}\right)$ & 4.11 & 4.18 & 0.07 & 6.03 & 6.14 & 0.11 \\
\hline (iii) Quote spread (\%) & 3.34 & 3.68 & $0.34^{* * *}$ & 3.67 & 3.93 & $0.26^{* * *}$ \\
\hline (iv) Effective spread (\%) & 1.64 & 1.76 & $0.12^{* *}$ & 1.80 & 1.89 & 0.09 \\
\hline (v) Pastor-Stambaugh measure $\left(\times 10^{-7}\right)$ & 4.28 & 0.75 & $-3.53^{*}$ & 12.64 & 1.58 & -11.06 \\
\hline (vi) Information asymmetry cost IAC $(\theta)$ & 0.62 & 0.63 & 0.01 & 0.78 & 0.79 & 0.01 \\
\hline (vii) Proportion of IAC $(\pi)$ & 0.43 & 0.44 & 0.01 & 0.46 & 0.47 & 0.01 \\
\hline \multicolumn{7}{|c|}{$\begin{array}{l}\text { Panel B. DID regression } \\
Y_{i, t}=\beta_{0}+\beta_{1} \text { Time }_{i, t}+\beta_{2} \text { Group }_{i, t}+\beta_{3} \text { Time }_{i, t} * \text { Group }_{i, t}+\varepsilon_{i, t}\end{array}$} \\
\hline & \multicolumn{3}{|c|}{ One-year window } & \multicolumn{3}{|c|}{ Six-month window } \\
\hline & $\beta_{1}$ & $\beta_{2}$ & $\beta_{3}$ & $\beta_{1}$ & $\beta_{2}$ & $\beta_{3}$ \\
\hline (i) Turnover ratio (\%) & 0.05 & 0.62 & 0.24 & 0.03 & 0.59 & 0.23 \\
\hline (ii) Amihud illiquidity measure $\left(\times 10^{-2}\right)$ & 0.07 & -4.10 & -0.06 & 0.10 & -6.04 & -0.10 \\
\hline (iii) Quote spread (\%) & 0.34 & -2.18 & -0.27 & 0.26 & -2.46 & -0.17 \\
\hline (iv) Effective spread (\%) & 0.12 & -1.02 & -0.10 & 0.09 & -1.16 & -0.03 \\
\hline (v) Pastor-Stambaugh measure $\left(\times 10^{-7}\right)$ & -3.53 & -4.18 & $3.49^{*}$ & -11.06 & -12.56 & 11.06 \\
\hline (vi) Information asymmetry cost IAC $(\theta)$ & 0.01 & -0.50 & -0.04 & 0.01 & -0.66 & 0.01 \\
\hline (vii) Proportion of IAC $(\pi)$ & 0.01 & -0.11 & $-0.11^{* * *}$ & 0.01 & -0.14 & -0.06 \\
\hline
\end{tabular}

frequency firms. For example, the changes of $\theta$ and $\pi$ during the one-year window around the MSS event are -0.04 and -0.10 , respectively, and significant at the $1 \%$ level for high trading frequency firms, but are close to zero and insignificant for low trading frequency firms. The results of the six-month window are similar.

The results in Panel B show that the $\beta_{3}$ is significantly negative for $\pi$ during the one-year window. This finding suggests that the negative impact of the MSS on the information asymmetry 
of high trading frequency firms is significantly stronger than that of low trading frequency firms.

In summary, I find that the impact of the MSS on the liquidity of different trading frequency firms is inconclusive, and that the MSS event mainly reduces the information asymmetry of high trading frequency firms.

Table 2.6. Liquidity and informed trading level for high and low turnover ratio firms

This table reports the liquidity and informed trading measures for high and low turnover ratio firms around the MSS. High (low) turnover rate firms are firms on the top (bottom) 33\% of the sample firms by their average turnover ratios in one year or six months before the MSS implementation. Panel A reports the means of liquidity or informed trading measures before (pre-change) and after (post-change) the MSS implementation, followed by the pair-match $t$-test for their difference. Panel B reports the coefficients of DID regressions to test how the MSS differently impacts the change of these measures between high and low turnover ratio firms. The sample size is $282 .{ }^{* * *},{ }^{* *}$, and ${ }^{*}$ indicate significance at the $1 \%, 5 \%$, and $10 \%$ level, respectively.

\begin{tabular}{|c|c|c|c|c|c|c|}
\hline \multicolumn{7}{|l|}{ Panel A. Sample results } \\
\hline & \multicolumn{3}{|c|}{ One-year window } & \multicolumn{3}{|c|}{ Six-month window } \\
\hline & $\begin{array}{l}\text { Pre-change } \\
\text { (1) }\end{array}$ & $\begin{array}{l}\text { Post-change } \\
\text { (2) }\end{array}$ & $\begin{array}{l}\text { Difference } \\
(2-1)\end{array}$ & $\begin{array}{l}\text { Pre-change } \\
\text { (4) }\end{array}$ & $\begin{array}{l}\text { Post-change } \\
\quad \text { (5) }\end{array}$ & $\begin{array}{l}\text { Difference } \\
(5-4)\end{array}$ \\
\hline \multicolumn{7}{|l|}{ High turnover rate } \\
\hline (i) Turnover ratio (\%) & 0.79 & 1.05 & 0.26 & 0.70 & 0.91 & 0.21 \\
\hline (ii) Amihud illiquidity measure $\left(\times 10^{-2}\right)$ & 0.13 & 0.50 & $0.37^{*}$ & 0.19 & 0.62 & 0.43 \\
\hline (iii) Quote spread (\%) & 1.50 & 1.74 & $0.24^{* * *}$ & 1.63 & 1.83 & $0.20^{* * *}$ \\
\hline (iv) Effective spread (\%) & 0.77 & 0.88 & $0.11^{* * *}$ & 0.83 & 0.94 & $0.11^{* *}$ \\
\hline (v) Pastor-Stambaugh measure $\left(\times 10^{-7}\right)$ & 0.14 & 0.13 & -0.01 & 0.11 & 0.19 & $0.08^{*}$ \\
\hline (vi) Information asymmetry cost IAC $(\theta)$ & 0.18 & 0.15 & $-0.03^{* * *}$ & 0.18 & 0.23 & 0.05 \\
\hline (vii) Proportion of IAC $(\pi)$ & 0.33 & 0.25 & $-0.08^{* * *}$ & 0.31 & 0.28 & -0.02 \\
\hline \multicolumn{7}{|l|}{ Low turnover rate } \\
\hline (i) Turnover ratio (\%) & 0.04 & 0.08 & $0.04^{* * *}$ & 0.02 & 0.08 & $0.06^{* * *}$ \\
\hline (ii) Amihud illiquidity measure (\%) & 3.15 & 3.36 & 0.21 & 4.76 & 5.06 & 0.30 \\
\hline (iii) Quote spread (\%) & 2.81 & 3.00 & 0.19 & 3.29 & 3.33 & 0.04 \\
\hline (iv) Effective spread (\%) & 1.38 & 1.42 & 0.04 & 1.60 & 1.60 & 0.00 \\
\hline (v) Pastor-Stambaugh measure $\left(\times 10^{-7}\right)$ & 4.18 & 0.69 & -3.49 & 12.78 & 1.37 & -11.42 \\
\hline (vi) Information asymmetry cost IAC $(\theta)$ & 0.50 & 0.51 & 0.01 & 0.69 & 0.62 & -0.07 \\
\hline (vii) Proportion of IAC $(\pi)$ & 0.43 & 0.42 & -0.01 & 0.44 & 0.42 & -0.02 \\
\hline \multicolumn{7}{|c|}{$\begin{array}{l}\text { Panel B. DID regression } \\
Y_{i, t}=\beta_{0}+\beta_{1} \text { Time }_{i, t}+\beta_{2} \text { Group }_{i, t}+\beta_{3} \text { Time }_{i, t} * \text { Group }_{i, t}+\varepsilon_{i, t}\end{array}$} \\
\hline & \multicolumn{3}{|c|}{ One-year window } & \multicolumn{3}{|c|}{ Six-month window } \\
\hline & $\beta_{1}$ & $\beta_{2}$ & $\beta_{3}$ & $\beta_{1}$ & $\beta_{2}$ & $\beta_{3}$ \\
\hline (i) Turnover ratio (\%) & 0.04 & 0.74 & 0.22 & 0.05 & 0.68 & 0.15 \\
\hline (ii) Amihud illiquidity measure $\left(\times 10^{-2}\right)$ & 0.21 & -0.03 & 0.16 & 0.30 & -4.58 & 0.13 \\
\hline (iii) Quote spread (\%) & 0.19 & -1.31 & 0.07 & 0.04 & -1.66 & 0.16 \\
\hline (iv) Effective spread (\%) & 0.04 & -0.60 & 0.07 & 0.00 & -0.77 & 0.11 \\
\hline (v) Pastor-Stambaugh measure $\left(\times 10^{-7}\right)$ & -3.49 & -4.04 & 3.48 & -11.42 & -12.67 & 11.50 \\
\hline (vi) Information asymmetry cost IAC $(\theta)$ & 0.01 & -0.33 & -0.04 & -0.07 & -0.51 & 0.13 \\
\hline (vii) Proportion of IAC $(\pi)$ & -0.01 & -0.10 & $-0.07^{* *}$ & -0.02 & -0.14 & 0.00 \\
\hline
\end{tabular}


Table 2.6 reports the results for the firms grouped by turnover ratio. Similar to Tables 2.4 and 2.5, I report the sample mean in Panel A and run the DID regressions in Panel B. The liquidity measures of high turnover ratio firms, including the Amihud measure, quoted spread, and effective spread, significantly increase after the MSS event. These results imply that the stocks of high turnover ratio firms become less liquid after the implementation of the MSS. In contrast, the informed trading measures for these firms significantly decline after the MSS event. For example, the $\theta$ and $\pi$ of high turnover ratio firms drop by 0.03 and 0.08 , respectively, during the one-year window. These changes are significant at the $1 \%$ level. The impact of the MSS on low turnover ratio firms is insignificant. In summary, I find that the MSS mainly affects high turnover ratio firms. They lost their stock liquidity, but their informed trading level is improved.

The finding that high turnover ratio (trading frequency) firms lost their liquidity but their informed trading level is improved may catch my readers. These results at first seem contrasting to the literature on the extend that a lower informed trading level should be associated with a more liquid market. However, I offer two possible explanations to justify these results.

First, prior studies have shown that the liquidity impact of secondary stock market regulation may have two opposite effects. On the one hand, if informed trading does improve, the adverse selection problem of uninformed investors trading with an informed trader would reduce and other market participants would have enough incentives to trade more actively. This will lead to improved market liquidity (Kyle, 1985; Bhattacharya and Spiegel, 1991; Easley and O'hara, 2004). On the other hand, there is evidence that insiders tend to exhibit an abnormally high level of trading activity (Easley and O'hara, 1987; Meulbroek, 1992). Insider trading restriction will refrain them from conducting transactions for which the marginal benefits are lower than the increased marginal costs (Palan and Stöckl, 2017). The less-developed structure of the Vietnam capital market means that a significant portion of market participants involve trading activities that will be captured by the newly introduced surveillance system as abnormal or insider and subject to sanctions. Refraining these participants from the market means that the liquidity contributed by the participants would also be withdrawn, at least in the short run. This impact decreases the whole 
market liquidity including that of high turnover ratio (trading frequency) firms.

Second, the rules underlying a new surveillance system can always come with ambiguities, which might not only refrain the market manipulators but also hold back legal market investors. In other words, there is a learning period for investors to adapt to the new regulatory regime. The negative effect of rule ambiguities on liquidity can be further aggravated when compounded with a less developed legal system in Vietnam. Since the violation of the rules can be consequential (e.g., criminal conviction for an illegal trading profit of US\$22,500), the market investors may need even longer time to learn and digest what kind of trading activities are permitted or banned by the new system.

\subsubsection{Graph the market quality}

To provide a picture of how the market quality measures of different firms change with the time, I plot the liquidity and informed trading measures of the top and bottom group in each quarter in Figure 2.1. I plot one year before until one year after the MSS event. The left, middle, and right columns plot the results sorted by firm size, trading frequency, and turnover ratio, respectively.

The patterns are consistent with the results reported in Tables 2.4 to 2.6. For example, the quoted spreads of small firms increase more than large firms after the MSS event. This result is consistent with the findings in Table 2.4. The proportion of information asymmetry becomes smaller after the MSS event for high trading frequency firms. This pattern is consistent with the results in Table 2.5 . 


\section{Panel A. Liquidity}

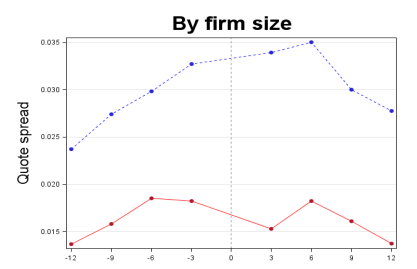

By trading frequency
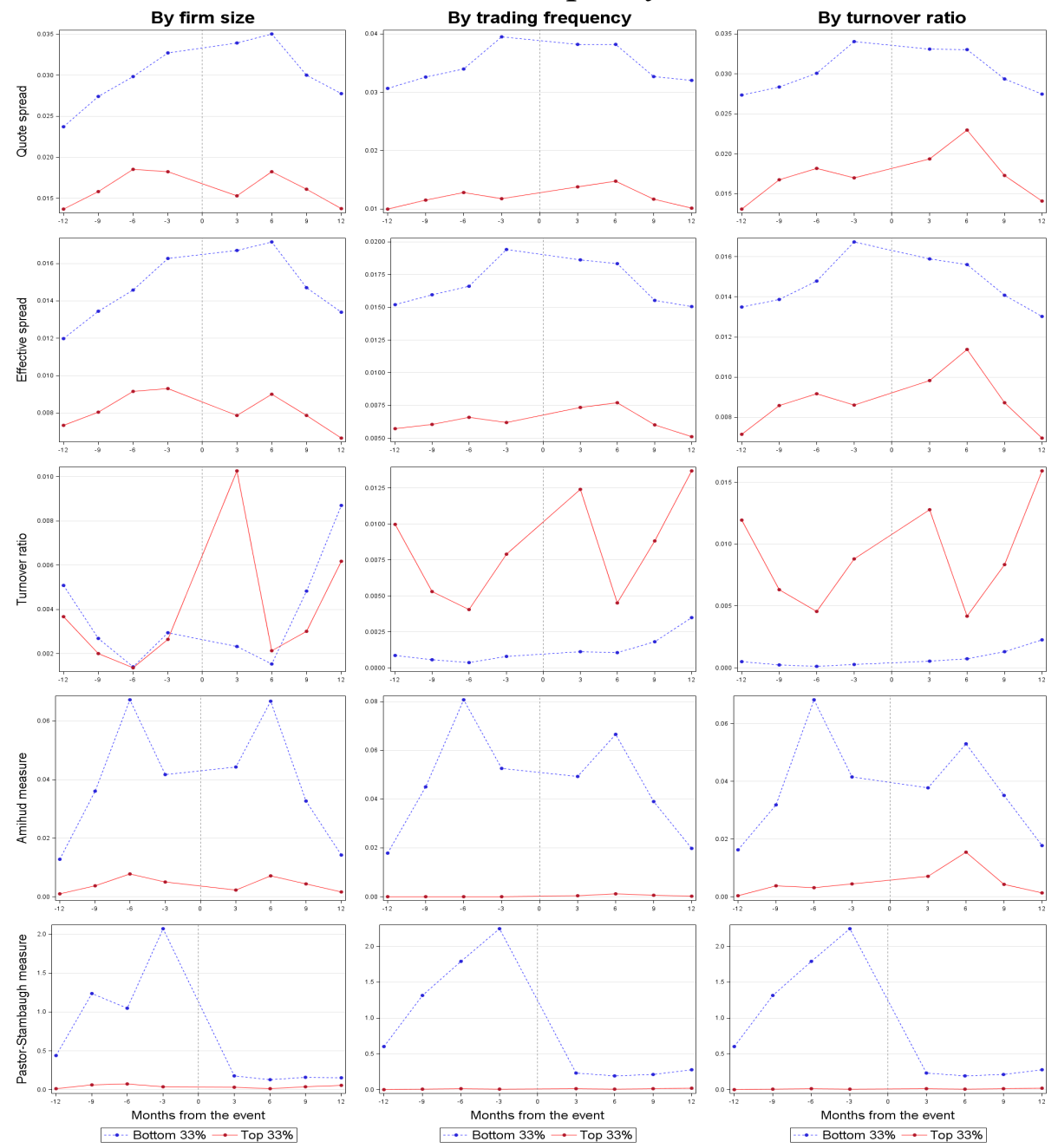

\section{Panel B. Informed trading}
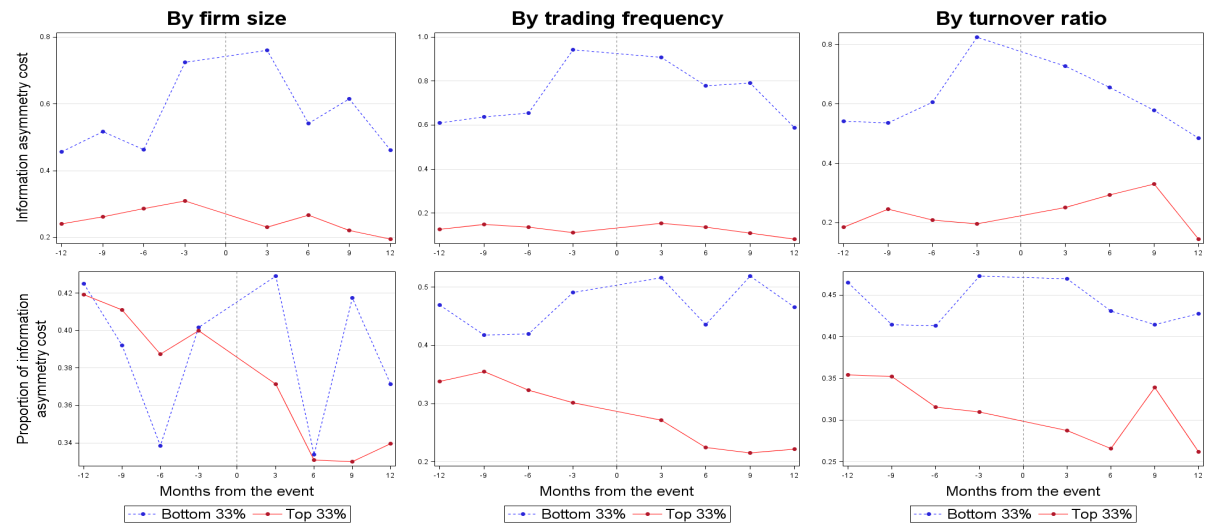

Figure 2.1. Liquidity and informed trading of top and bottom groups over time

This figure plots the liquidity and informed trading measures of the top and bottom group of sample firms sorted by each firm characteristics variable, including firm size, trading frequency, and turnover ratio. Each chart presents the cross-sectional average of liquidity and informed trading measures every three months during one year before until one year after the MSS event. 


\subsubsection{Cross-sectional regression}

In this section, I run cross-sectional regressions of market quality measure change on selected firm characteristics variables to further investigate the relationship between firm characteristics and the MSS impact. I consider six firm characteristics variables: firm size, trading frequency, turnover ratio, trading volume, $\mathrm{P} / \mathrm{E}$ ratio, and the dummy variable for financial firms.

$$
\begin{aligned}
\triangle m_{i, t}= & \alpha+\beta_{1} \ln \left(\text { size }_{i,(t-1)}+\beta_{2} \ln (\text { tradingfreq })_{i,(t-1)}+\beta_{3} \text { turnover }_{i,(t-1)}\right. \\
& +\beta_{4} \ln (\text { tradingvol })_{i,(t-1)}+\beta_{5} P E_{i,(t-1)}+\beta_{6} \text { IINA }_{i,(t-1)}+\varepsilon_{i, t},
\end{aligned}
$$

where $\triangle m$ is the difference of the selected quality measure before and after the MSS implementation. $\ln ($ size $), \ln$ (tradingfreq) and $\ln$ (tradingvol) are the natural logarithm of firms' average market capitalization, average number of transactions executed per day, and daily trading volume. turnover is firms' turnover ratio. $P E$ is the $\mathrm{P} / \mathrm{E}$ ratio, and FINA is a dummy variable that equals to 1 if the firm is a financial firm and 0 otherwise. I consider two time windows: one-year and six-months around the MSS event.

Table 2.7 reports the regression results. The left and right columns indicate the results of the one-year and six-month window, respectively. I find a negative relationship between firm size and liquidity measure change. This relationship is significant and robust after controlling for other variables and in both periods. For example, in the one-year window, the coefficient of $\beta_{1}$ for the Amihud measure is negative and significant at the 5\% level. Since the MSS overall negatively affects the market liquidity of the Vietnam stock market, these regression results suggest that the worsening effect of the MSS on liquidity is stronger for small firms.

I also document a negative relationship between firm's trading frequency and liquidity measure change. The coefficients $\beta_{2}$ of all full regressions are negative for the Amihud measure, quoted spread, effective spread, and the Pastor-Stambaugh measure, while it is positive for turnover ratio. These results, along with the fact of an overall decline of market liquidity after the MSS implementation, show that low trading frequency firms are more negatively affected by the MSS.

The regression results of the information asymmetric measure $\theta$ are weaker than those of the liquidity measure. The coefficients of firm size and trading frequency are significantly negative 


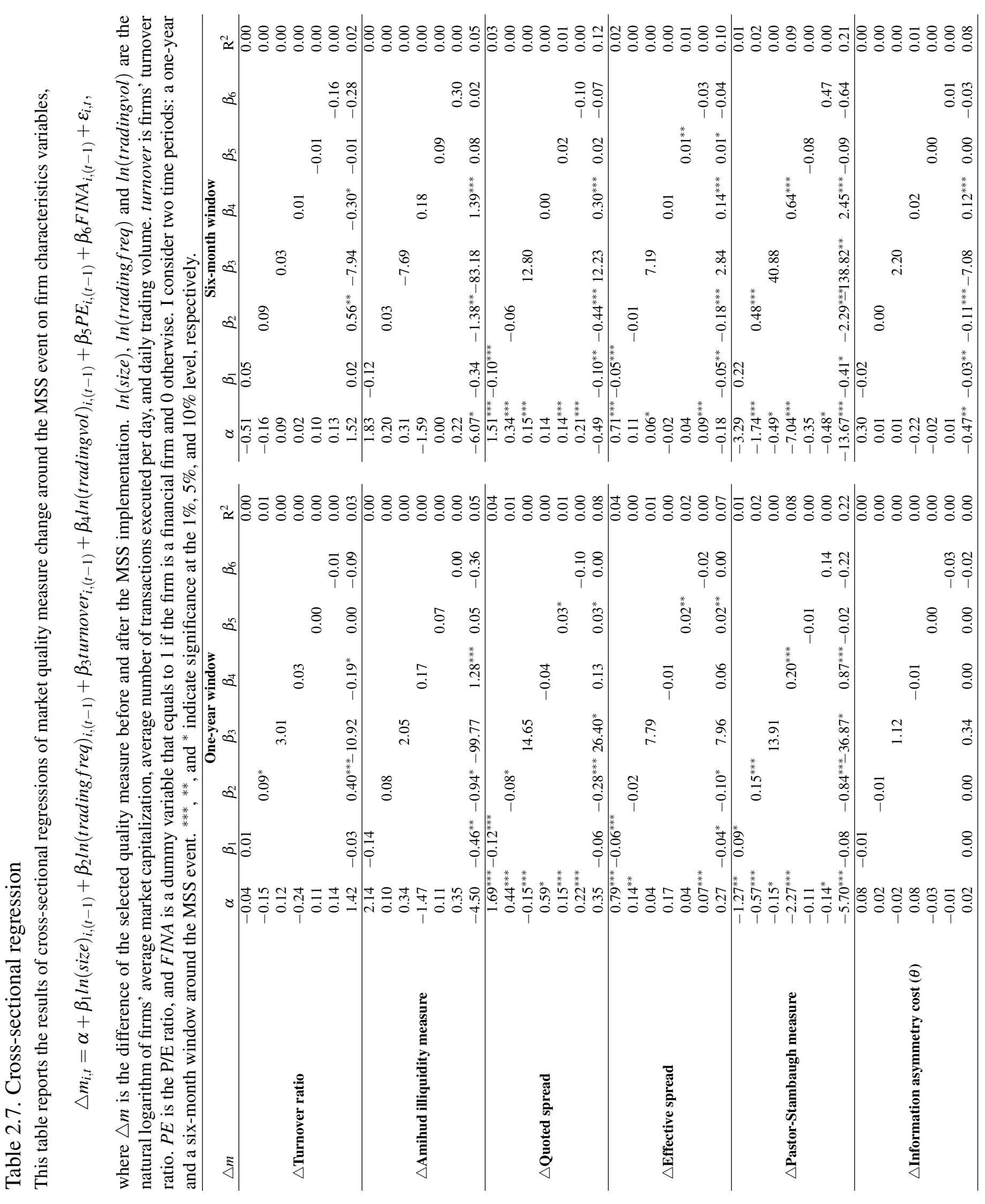


during the six-month window when all variables are used in the regression. These results, along with the overall outcome of no significant impact of the MSS on the information asymmetry, show that large firms and high trading volume firms tend to have an improved informed trading level at the Vietnam stock market. These results are consistent with those reported in Tables 2.4 to 2.6.

\subsection{Discussion on other confounding events}

In this section, I investigate whether there exist other simultaneous policy changes that might affect the market liquidity and informed trading at the Vietnam stock market. I manually collect all the regulations and policies of the Vietnam stock market in the sample period and qualitatively discuss whether they might affect Vietnam stock market trading activities.

Table 2.8 lists all the regulations, circulars, and policies related to the Vietnam stock market from December 2011 to March 2014. ${ }^{11}$ Most of the policies listed in Table 2.8 did not target the market activity but the corporate governance of securities institutions. For example, Circular No. 91/2013/TT-BTC, issued on 28 June 2013, provides guidelines for the registration of the establishment, organization, and operation of representative offices of foreign securities institutions and branches of foreign fund management companies in Vietnam. It directly influences the operation of the foreign institutions but not the order flow of the stock market.

Among all the policies, Circular No. 2/2012/TT-BTC is about the disclosure of information on the securities market, which might affect the trading activities of the Vietnam stock market. For example, this circular requires that public companies must disclose financial and non-financial information on fixed dates; public companies do not need to report to the State Securities Commission of Vietnam when their stock prices have exceeded the daily ceiling or floor prices until the excesses happen continuously in five trading days; only big companies (those capitalized at more than 120 billion VND and possessed by more than 300 shareholders) need to report to the State Securities Commission when their stock prices have exceeded the daily ceiling or floor prices on

\footnotetext{
${ }^{11}$ These documents are available on the official website of the State Securities Commission of Vietnam.
} 
Table 2.8. Regulation of the Vietnam stock market during 12/2011-03/2014

This table lists the regulations, circulars, and policies of the Vietnam stock market from December 2011 to March 2014. These documents are available on the official website of State Securities Commission of Vietnam.

\begin{tabular}{|c|c|c|}
\hline Official number & Date & Name \\
\hline No.366-QD-TTg & $11 / 03 / 2014$ & $\begin{array}{l}\text { The Decision approving plan on formation and development of } \\
\text { the Vietnam derivative securities market. }\end{array}$ \\
\hline 216/2013/TT-BTC & $31 / 12 / 2013$ & $\begin{array}{l}\text { Circular amending Circular No. 38/2011/TT-BTC dated } \\
\text { 16/3/2011 stipulating the rate, collection-payment regime, man- } \\
\text { agement and use of fees from securities operations applying with } \\
\text { security service organizations. }\end{array}$ \\
\hline 217/2013/TT-BTC & $31 / 12 / 2013$ & $\begin{array}{l}\text { Circular guiding on administrative penalties for violations in the } \\
\text { field of securities and securities market. }\end{array}$ \\
\hline 108/2013/ND-CP & $23 / 09 / 2013$ & $\begin{array}{l}\text { Decree administrative penalties for violations insecurities and se- } \\
\text { curities market. }\end{array}$ \\
\hline 91/2013/TT-BTC & $28 / 06 / 2013$ & $\begin{array}{l}\text { Circular providing guidelines for registration of establishment, } \\
\text { organization and operation of representative offices of foreign se- } \\
\text { curities business institutions and branches of foreign fund man- } \\
\text { agement companies in Vietnam. }\end{array}$ \\
\hline 73/2013/TT-BTC & $29 / 05 / 2013$ & $\begin{array}{l}\text { Circular guiding in details a number of articles about securities } \\
\text { listing at the Decree No. 58/2012/ND-CP dated 20/7/2012. }\end{array}$ \\
\hline 165/2012/TT-BTC & $30 / 12 / 2012$ & $\begin{array}{l}\text { Circular Amending and Supplementing a number of Articles of } \\
\text { the Circular No.226/2010/TT-BTC dated } 31 / 12 / 2010 \text { of the Min- } \\
\text { istry of Finance, on the prudential ratio and the handling measures } \\
\text { for the securities institutions that fail to achieve the prudential ra- } \\
\text { tio. }\end{array}$ \\
\hline 229/2012/TT-BTC & $27 / 12 / 2012$ & $\begin{array}{l}\text { Circular Guiding Establishment and Management of Exchange } \\
\text { Traded Funds. }\end{array}$ \\
\hline 227/2012/TT-BTC & $27 / 12 / 2012$ & $\begin{array}{l}\text { Circular Guiding the Establishment, Organization and Manage- } \\
\text { ment of investment companies }\end{array}$ \\
\hline 228/2012/TT-BTC & $27 / 12 / 2012$ & $\begin{array}{l}\text { Circular guiding establishment and management of real estate in- } \\
\text { vestment funds }\end{array}$ \\
\hline 212/2012/TT-BTC & $05 / 12 / 2012$ & $\begin{array}{l}\text { Circular Request form for Certificate for establishment and oper- } \\
\text { ation registration of fund management companies. }\end{array}$ \\
\hline 210/2012/TT-BTC & $30 / 11 / 2012$ & $\begin{array}{l}\text { Circular providing guidelines on establishment of securities com- } \\
\text { panies. }\end{array}$ \\
\hline 121/2012/TT-BTC & $26 / 07 / 2012$ & $\begin{array}{l}\text { Circular providing regulations on corporate governance applica- } \\
\text { ble to public companies. }\end{array}$ \\
\hline 58/2012/ND-CP & 20/07/2012 & $\begin{array}{l}\text { Decree providing detailed regulations for implementation of a } \\
\text { number of Articles of the Law on Securities (Amended). }\end{array}$ \\
\hline No.58-2012-ND-CP & 20/07/2012 & $\begin{array}{l}\text { The Decree providing detailed regulations for implementation of } \\
\text { a number of articles of the law on securities (amended) dated } 20 \\
\text { July } 2012 \text { as amended by Decree } 60 \text { dated } 26 \text { June } 2015 \text {. }\end{array}$ \\
\hline 52/2012/TT-BTC & 05/04/2012 & Circular on disclosure of information on the securities market. \\
\hline 183/2011/TT-BTC & $16 / 12 / 2011$ & $\begin{array}{l}\text { Circular guiding establishment and management of open end in- } \\
\text { vestment funds. }\end{array}$ \\
\hline
\end{tabular}


10 continuous trading days. However, this policy was implemented on 4 May 2012, which is the beginning of my sample period. As a result, this policy only potentially affects the market quality in both the pre- and post-change periods and is not the event that will drive my empirical results.

\subsection{Robustness tests}

In this section, I conduct two tests to check the robustness of my empirical results. In the first set, I use $20 \%$ and $80 \%$ percentile values of each firm characteristics variable to identify the firms in the top and bottom group and report the results in Table 2.9.

I report the change of each market quality measure for the top and bottom groups and their difference. The difference is tested using DID regression. Results are similar to those reported in Tables 2.4 to 2.6. Liquidity becomes worse for small firms after the MSS event. For example, the

quoted spreads of small firms increase by $0.58 \%$ in the one-year window, while they decrease by $0.06 \%$ for larger firms. Their difference is $-0.64 \%$ and significant at the $5 \%$ level. The results of the spreads in the six-month window are similar. Meanwhile, the informed trading level is improved for large, high trading frequency and high turnover ratio firms after the MSS event.

In the second test, I use a sample of a one-year window but exclude the three months before and after the MSS implementation to control for the possible policy uncertainty around the event.

Table 2.10 reports the results. The left and right columns indicate the results using $(33 \%, 66 \%)$ and $(20 \%, 80 \%)$ percentile values, respectively. The main conclusions still hold. The results of Tables 2.9 and 2.10 suggest that my empirical findings are robust to the choice of critical values to group the stocks, and the sample period used in the analysis. 
Table 2.9. Robustness test 1: Using $20 \%$ and $80 \%$ percentile values

This table reports the results of market quality measure change using $20 \%$ and $80 \%$ percentile values to group firms. I report the results of liquidity and informed trading change for the top and bottom groups and their differences. The significance of the changes of the top and bottom groups is tested using the pair-matched $t$-test, while the significance of the difference is tested using DID regression. The left and right columns report the results of the one-year and six-month window, respectively. ${ }^{* * *},{ }^{* *}$, and ${ }^{*}$ indicate significance at the $1 \%$, $5 \%$, and $10 \%$ level, respectively.

\begin{tabular}{|c|c|c|c|c|c|c|}
\hline & \multicolumn{3}{|c|}{ One-year window } & \multicolumn{3}{|c|}{ Six-month window } \\
\hline & $\begin{array}{l}\text { Top } \\
\text { (1) }\end{array}$ & $\begin{array}{l}\text { Bottom } \\
\text { (2) }\end{array}$ & $\begin{array}{c}\text { Top-Bottom } \\
(1-2)\end{array}$ & $\begin{array}{l}\text { Top } \\
\text { (4) }\end{array}$ & $\begin{array}{c}\text { Bottom } \\
(5)\end{array}$ & $\begin{array}{c}\text { Top-Bottom } \\
(4-5)\end{array}$ \\
\hline \multicolumn{7}{|l|}{ Firm size } \\
\hline (i)Turnover ratio (\%) & $0.06^{* * *}$ & * 0.06 & 0.00 & 0.02 & -0.05 & 0.07 \\
\hline (ii)Amihud illiquidity measure $\left(\times 10^{-2}\right)$ & -0.03 & 0.99 & -1.02 & -0.15 & 0.82 & -0.97 \\
\hline (iii)Quote spread (\%) & -0.06 & $0.58^{* * *}$ & $-0.64^{* *}$ & $-0.12^{*}$ & $0.38^{* * *}$ & -0.50 \\
\hline (iv)Effective spread (\%) & -0.04 & $0.29^{* * *}$ & $-0.33^{* * *}$ & -0.05 & $0.22^{* * *}$ & -0.27 \\
\hline (v)Pastor-Stambaugh measure $\left(\times 10^{-7}\right)$ & 0.06 & -4.96 & 5.02 & -0.01 & -5.30 & 5.29 \\
\hline$(v i)$ Information asymmetry cost IAC $(\theta)$ & $-0.05^{* * *}$ & * 0.01 & -0.06 & -0.01 & 0.15 & -0.16 \\
\hline (vii)Proportion of IAC $(\pi)$ & $-0.09^{* * *}$ & *-0.02 & $-0.07^{*}$ & $-0.04^{* *}$ & 0.03 & -0.07 \\
\hline \multicolumn{7}{|l|}{ Trading frequency } \\
\hline (i)Turnover ratio (\%) & 0.38 & 0.00 & 0.38 & 0.43 & 0.00 & 0.42 \\
\hline (ii)Amihud illiquidity measure $\left(\times 10^{-2}\right)$ & 0.00 & -0.32 & 0.32 & 0.00 & -0.26 & 0.26 \\
\hline (iii)Quote spread (\%) & $0.09^{*}$ & $0.46^{* * *}$ & $-0.37^{*}$ & 0.06 & $0.42^{* *}$ & -0.36 \\
\hline (iv)Effective spread (\%) & 0.03 & $0.15^{* *}$ & -0.12 & 0.03 & 0.15 & -0.12 \\
\hline (v)Pastor-Stambaugh measure $\left(\times 10^{-7}\right)$ & $0.27^{*}$ & -5.36 & 5.39 & 0.00 & -18.56 & 18.56 \\
\hline$(v i)$ Information asymmetry cost IAC $(\theta)$ & $-0.03^{* * *}$ & * 0.02 & -0.05 & 0.00 & 0.04 & -0.04 \\
\hline (vii)Proportion of IAC $(\pi)$ & $-0.10^{* * *}$ & $* 0.01$ & $-0.11^{* * *}$ & $-0.06^{* *}$ & $* 0.00$ & -0.06 \\
\hline \multicolumn{7}{|l|}{ Turnover ratio } \\
\hline (i)Turnover ratio (\%) & 0.43 & $0.02^{* * *}$ & 0.40 & 0.35 & $0.05^{* * *}$ & 0.30 \\
\hline (ii)Amihud illiquidity measure $\left(\times 10^{-2}\right)$ & 0.45 & -0.16 & 0.61 & 0.02 & -0.17 & 0.19 \\
\hline (iii)Quote spread (\%) & $0.23^{* * *}$ & * $0.30^{* *}$ & -0.07 & $0.24^{* *}$ & $*-0.04$ & 0.28 \\
\hline (iv)Effective spread (\%) & $0.09^{* *}$ & 0.09 & 0.00 & $0.13^{* *}$ & -0.04 & 0.17 \\
\hline (v)Pastor-Stambaugh measure $\left(\times 10^{-7}\right)$ & 0.02 & -5.24 & 5.26 & 0.02 & -19.03 & 19.05 \\
\hline$(v i)$ Information asymmetry cost IAC $(\theta)$ & $-0.03^{* * *}$ & * 0.02 & -0.05 & 0.04 & $-0.14^{*}$ & 0.18 \\
\hline (vii)Proportion of IAC $(\pi)$ & $-0.09^{* * *}$ & *-0.01 & $-0.11^{* * *}$ & $-0.04^{* *}$ & -0.05 & 0.01 \\
\hline
\end{tabular}


Table 2.10. Robustness test 2: Excluding three months before and after the MSS

This table reports the results of market quality change using the data of the one-year window, excluding three months before and after the MSS implementation. I report the results of liquidity and informed trading change for the top and bottom group and their differences. The significance of the changes of top and bottom groups is tested using the pair-matched $t$-test, while the significance of the difference is tested using DID regression. The left and right columns report the results using $(33 \%, 66 \%)$ and $(20 \%, 80 \%)$ to group the firms, respectively. ${ }^{* * *}$, ${ }^{* *}$, and ${ }^{*}$ indicate significance at the $1 \%, 5 \%$, and $10 \%$ level, respectively.

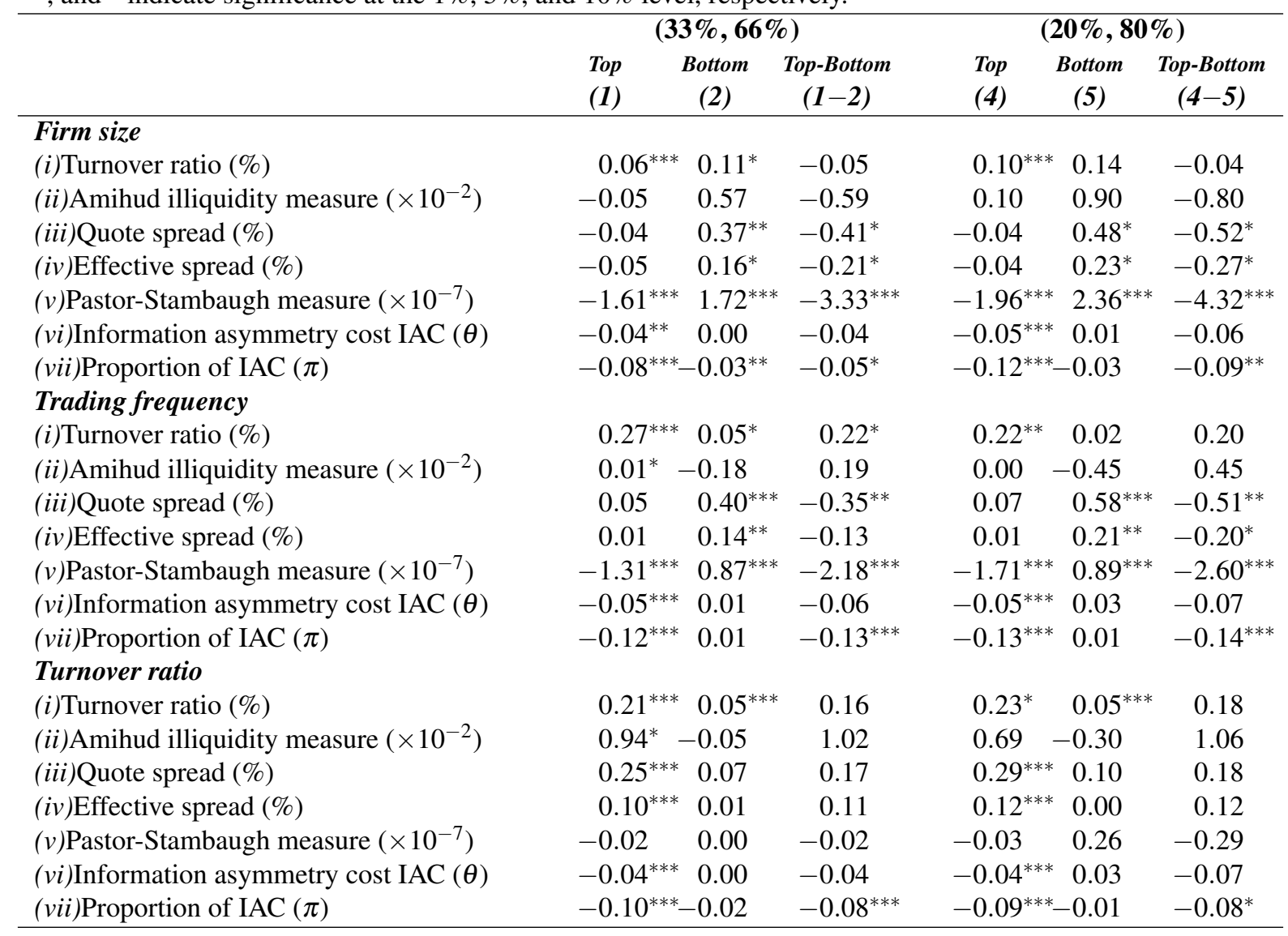

\subsection{Conclusion}

In this chapter, I investigate the effectiveness of the MSS on improving the market quality of the Vietnam stock market. I document that the aggregate market quality of the Vietnam stock market does not improve after the MSS implementation. In contrast, the liquidity measures, especially bidask spreads, significantly increase after the event. This finding suggests market liquidity becomes worse. I also find no evidence of the improvement of informed trading. These findings, together with other literature that documents the ineffectiveness of regulation policy, suggest that stock market regulation is a complicated issue. Another possible reason is that it takes longer time for 
the policy to generate positive effect. More robust policy evaluation is necessary to help it achieve the target.

I also find that different firms are affected by the MSS differently. MSS mainly negatively affects the liquidity of small firms. Meanwhile, it also improves the informed trading of large, high trading frequency and high turnover ratio firms. These results suggest that policy affects different firms to a varying degree. An analysis of the different response by different firms will help improve the effectiveness of a regulation policy in a financial market. 



\section{Chapter 3}

\section{Corporate Governance and Informed Trading in the Vietnam Stock Market}

\subsection{Introduction}

Informed trading is firstly considered as trading on information not yet reflected in a stock's price. Such informational advantages can arise from astute analysis of varied pieces of public news, from just released public information, or from confidential information from inside a firm. To this perspective, informed trading makes share prices more accurate, which enhances the allocation of capital, but also makes markets less liquid, which is costly to the efficiency of trade (Fox, Glosten, and Rauterberg, 2018). Shortly, informed trading leads to more accurate share prices but reduces market liquidity (Wong, Tan, and Tian, 2009). As the second understanding, informed trading is also likely to be driven by illegal insider information that is under strict regulation (see, for example, Meulbroek, 1992; Bhattacharya and Daouk, 2002; Acharya and Johnson, 2007; Ahern, 2017). To outsider investors' perspective, informed trading generally involves insiders' trades in which managers trade for their own benefit at the expense of shareholders. In general, informed trading is likely related to negative impacts to the market. As a result, regulators and market participants will ask for a reduction of informed trading. 
On the other hand, corporate governance (CG) is a set of mechanisms through which outside investors can protect themselves against expropriation by insiders (Porta, de Silanes, Shleifer, and Vishny, 2000). Specifically, the purpose of CG is to help build an environment of trust, transparency, and accountability (OECD, 2015). Then, well-governed firms are expected to have better disclosure and transparency mechanisms. Such an environment discourages informed traders who exploit private information. As a result, a firm with better CG practices is associated with a lower level of informed stock trading.

In this chapter, I provide empirical evidence for this hypothesis by examining the relationship between CG practices and the informed trading, measured by the CG score (CGS) and the information asymmetry cost (IAC), respectively. Firms' CGS is calculated using a self-constructed CG scorecard. This CG scorecard is a simplification of the Association of Southeast Asian Nations (ASEAN) CG scorecard, an assessment based on publicly available information and benchmarked against international best practices that encourage publicly listed companies to go beyond national legislative requirements. Since the scorecard is based on publicly available information, it reflects an outside shareholder's perspective of firms' CG practices. A higher score level means a better CG practices. I use the CGS under this scorecard as the independent variable in my regression. For the dependent variable, I use the firm IAC estimated from the Madhavan et al. (1997) MRR model using intraday prices. A greater value of IAC means a higher level of informed trading.

I examine the relationship between firms' $\mathrm{CG}$ practices and the informed trading level using data of firms listed in the Ho Chi Minh Exchange (HOSE) of the Vietnam market. There are some reasons for using this data. First, some firms listed in HOSE ${ }^{12}$ have their CGSs recorded on the ASEAN Corporate Governance Scorecard-Country Reports and Assessments ${ }^{13}$ annually since 2011. This fact helps the application of my CG scorecard, which is based on the structure of ASEAN CG scorecard, be more realistic. Second, Vietnam stock market has become more in-

\footnotetext{
${ }^{12}$ e.g. Saigon General Service Corporation, Hoa Phat Group Joint Stock Company, Hoa Sen Group.

${ }^{13}$ This report is a Joint Initiative of the ASEAN Capital Markets Forum and the Asian Development Bank, pressed annually from 2013.
} 
ternational in recent years. The Vietnam indices are watched by MSCI $^{14}$ and FTSE Russell ${ }^{15}$, and FTSE recently puts the Vietnam market on the watch list for possible reclassification to second-tier emerging market. This also supports the third reason, that I give an investigation of the informed trading in an emerging market, while recent literature focuses on developed markets (e.g. Anderson, Reeb, and Zhao, 2012; Dai, Fu, Kang, and Lee, 2016).

As a very first analysis, I examine the correlation matrix and run simple $t$-tests for the differences in IACs between high- and low-CGS firms. The results from both correlation matrix and $t$-tests suggest that firms with a lower CGS have a higher IAC. This result is consistent through time, indicating a negative relationship between the CGS and the IAC.

In the main regression, I regress the IAC on the CGS and control variables using the FamaMacBeth procedure. I use Newey-West procedure to adjust for the standard errors. The regression yields a negative coefficient on the CGS which is significant at the 5\% level. I then conduct subsample analysis of large or small firms, high- or low-trading-frequency firms, and firms with high or low turnover ratios. The negative relationship is pronounced for large firms, firms with high trading frequency, and firms with high turnover ratio. Hence, given that trading frequency and turnover ratio measure stock liquidity, the empirical results show that the negative relationship is strong for large and liquid firms.

I also examine whether the relationship is a causal one. I conduct $t$-tests for the changes in both CGSs and IACs of large and small, liquid and less liquid firms after the two circulars, which require a higher quality in the firms' CG practices. I observe that after the policies, the CGSs of all firms increase and their IACs decrease (except the IAC of high-turnover-ratio firms). Moreover, a greater increase in CGSs is associated with a greater decrease in IACs. For example, high-tradingfrequency firms have a greater increase in CGSs and also a greater decrease in IACs compared with low-trading-frequency firms. These results suggest a causal effect of CG practices on informed trading.

\footnotetext{
${ }^{14}$ MSCI is a provider of critical decision-support tools and services for the global investment community. See msci.com for more information.

${ }^{15}$ FTSE Russell is a British provider of stock market indices and associated data services, wholly owned by the London Stock Exchange and operating from premises in Canary Wharf. For further information, see ftserussel.com
} 
To examine how a strengthened market regulation reinforces the effectiveness of CG practices, I run the regression for sub-samples before and after the implementation of the market surveillance system (MSS). The coefficients of interest are negatively significant for subsample after the MSS, but not for the subsample before this surveillance system. So, the implementation of the MSS affects the relationship between $\mathrm{CG}$ practices and informed trading in the way that a stronger legal environment (coming from the MSS implementation) reinforces the effectiveness of CG practices on the informed trading. These results are consistent to the findings by Madhani (2016), Doidge, Karolyi, and Stulz (2007), Bergman and Nicolaievsky (2007), that legal environment for corporate governance and internal corporate governance are complementary. I give detail analysis by running the regression for large, small, liquid, and less liquid firms in periods before and after the application of the MSS. The coefficients of interest for large and liquid firms turn significant after the MSS. This suggests that the effect of the MSS implementation on the relationship is driven by large and liquid firms.

I also do a robustness check to emphasize the association between $\mathrm{CG}$ practices and informed trading level by examining the cumulative abnormal returns (CARs) around financial statement announcement. I find that in both cases of good news and bad news, high-CGS firms have lower CARs comparing to low-CGS firms. This confirms the findings of the negative relation between CG practices and informed trading level.

This chapter contributes to corporate governance literature that improving CG practices helps reduce the firm informed trading level. A vast literature has emphasized the corporate governance's positive effects on firms' value (Fauver, Hung, Li, and Taboada, 2017), firms' performance (Fich and Shivdasani, 2006; Cunat, Gine, and Guadalupe, 2012; Bernile, Bhagwat, and Yonker, 2018), or firms' risk (Mathew, Ibrahim, and Archbold, 2018). Meanwhile, recent researches document that a sound corporate governance discourages insider trades. For example, Dai et al. (2016) find that corporate governance reduces the probability of insider sales. They use the board independence and institutional ownership to proxy for the firm CG. In this chapter, I use the CG scorecard to record firms' CG practices. This CG scorecard can draw a whole picture of the firm CG, including 
the board and large investors.

The rest of the chapter is organized as follows. Section 2 describes the variable construction and methodology. Section 3 describes the data and the empirical results. Section 4 gives analysis of the relationship between the two variables around the implementation of the MSS. In Section 5, I conduct the robustness test, using CAR as another proxy for the informed trading level. Section 6 concludes.

\subsection{Variable construction and methodology}

\subsubsection{Information asymmetry cost (IAC)}

The information asymmetry cost (IAC) estimated from the MRR model is used as a proxy for firms' informed trading level. The literature provides various models to estimate firms' informationbased trading level: PIN (Easley, Kiefer, O’Hara, and Paperman, 1996), VPIN (Easley, López de Prado, and O'Hara, 2012), and MRR (Madhavan et al., 1997). PIN and VPIN were both developed as new measures of order flow toxicity. VPIN provides proxies for adverse selection risk similar to those obtained by the PIN model (Abad-Diaz and Yagüe, 2012). Importantly, while being based on volume imbalance and trade intensity in the construction, these measures might be contingent on satisfactory performance relative to suitable benchmarks (Andersen and Bondarenko, 2014), such as flash crash.

Differently, the MRR model provides metrics for price discovery and effective trading costs. This model advances recent papers in accessing the level of information-based trading in financial markets worldwide (Frijns et al., 2008; Frijns et al., 2013). One advantage of using the MRR model is that I can not only measure the information-based trading level but also the liquidity costs (the order-processing cost and inventory cost). This approach helps me understand the aggregate market movement in detail and, hence, give a good explanation for the current market conditions.

Followings are a general description of the MRR model and the estimated information asymmetry cost used as the proxy of the informed trading level. 
Let $\mu_{t}$ be the expected stock value at time $t$. The revision in belief of $\mu_{t}$ is the sum of order flow innovation and new public information which is random,

$$
\mu_{t}=\mu_{t-1}+\theta\left(x_{t}-\rho x_{t-1}\right)+\varepsilon_{t} .
$$

In this equation, $\theta$ captures the impact of order flow innovation on the expected stock value and measures information asymmetry. $\rho$ is the first-oder autocorrelation of order flow and $x_{t}-\rho x_{t-1}$ captures the order flow innovation. $x_{t}$ is an indicator variable for trade initiation. $x_{t}$ equals to 1 if the trade is buyer initiated, -1 if the trade is seller initiated, and zero otherwise. Let $\lambda$ denote the unconditional probability the transaction occurs within the quote spread, or $\lambda=\operatorname{Pr}\left[x_{t}=0\right]$, and assume that buys and sells are equally likely, we have $E\left[x_{t}\right]=0$ and $\operatorname{var}\left[x_{t}\right]=(1-\lambda)$.

The transaction price $p_{t}$ could be written as the sum of expected stock value, liquidity cost and stochastic rounding errors,

$$
p_{t}=\mu_{t}+\phi x_{t}+\xi_{t}
$$

where $\phi$ captures the liquidity impact and measures liquidity cost. The change of transaction price is then

$$
\Delta p_{t} \equiv p_{t}-p_{t-1}=(\phi+\theta) x_{t}-(\phi+\rho \theta) x_{t-1}+\varepsilon_{t}+\xi_{t}-\xi_{t-1}
$$

Following Madhavan et al. (1997), I use generalized method of moments (GMM) to estimate the model. The moment conditions are

$$
E\left(\begin{array}{l}
x_{t} x_{t-1}-x_{t-1}^{2} \rho \\
\left|x_{t}\right|-(1-\lambda) \\
z_{t}-\alpha \\
\left(z_{t}-\alpha\right) x_{t} \\
\left(z_{t}-\alpha\right) x_{t-1}
\end{array}\right)=0
$$

where $z_{t}=\varepsilon_{t}+\xi_{t}-\xi_{t-1}$. 
The estimated parameters include $\theta$ (the information asymmetry), $\phi$ (the liquidity cost), $\lambda$ (the probability a transaction takes place inside the spread), and $\rho$ (the autocorrelation of the order flow). I use $\theta$ as the main proxy for the informed trading level, and as the dependent variable in this chapter.

Before the estimation of $\theta$, I follow Madhavan et al. (1997) and apply the Lee and Ready (1991) method to identify the trade initiation direction. Specifically, a transaction is defined as a buyer initiation if the transaction price is higher than the previous price, or as a seller initiation if the transaction price is lower than the previous price.

\subsubsection{Corporate governance score}

Different ratings on CG have been proposed by institutions and academics around the world. Some foreign and international rating systems, such as Governance Metrics International (2004), Institutional Shareholder Services (2003), and S\&P, are used to estimate share value and to help investors make investment decisions by giving the necessary information on a level of corporate governance in rated companies (Khanchel, 2007). Many studies on corporate governance are based on the governance index developed by these organizations (Klapper and Love, 2004; Durnev and Kim, 2005; Brown and Caylor, 2006). Alternatively, some authors develop their own indexes. For example, Campos and Wilson (2002) develop a corporate governance measure, taking into account the OECD's (1999) principles of corporate governance. Gompers, Ishii, and Metrick (2003) compute a corporate governance index for 1,500 US companies consisting of 24 anti-takeover provisions and shareholders' rights. The standards of scoring the quality of corporate governance depend on the regulation applicable in a particular market, and may vary among researchers with their own purposes of the ranking that underlies the studies. Therefore, it is difficult to draw a general standard of CG scoring around the markets.

Recently, the ASEAN Capital Markets Forum and the Asian Development Bank jointly construct a corporate governance rating system named ASEAN Corporate Governance Scorecard (ASEAN CGS). This corporate governance rating system designed to raise the CG standards of 
ASEAN countries, launched in 2011.The scorecard started with the development of the methodology that underpins the Scorecard, culminating in the publication of country reports and assessments. One of the principles of the ASEAN scorecard is that the scorecard should be universal and applicable to different markets in ASEAN (Asian Development Bank, 2013).

In my study, I prefer to compute a CG scorecard which is based on the structure of the ASEAN scorecard because this scorecard is apparently closely related to the Vietnam market. Specifically, my CG scorecard includes three crucial elements: level 1 of the ASEAN CGS, the OECD principles of corporate governance, and the national codes, especially the versions of the Circular of the Vietnamese Ministry of Finance on the securities market. The first element is the ASEAN CGS, level 1. Level 1 of the ASEAN CG scorecard consists of 185 items, divided in five parts. Only 34 items are computed in Level 2 of the scorecard, but one may need detailed information, which is not available to individual researcher, to response to one item in level 2. My CG scorecard contains 52 questions totally, all in Level 1, and one question in my card may consist of more than one item in the ASEAN card. The second element of my CG scorecard is the OECD principles of CG which helps policy makers evaluate and improve the legal, regulatory, and institutional framework for CG (OECD, 2015), first published in 1999. The third element is the Circular of the Vietnamese Ministry of Finance which gives guidance on information disclosure on securities markets. This circular has three versions, implemented in 2010, 2012, and 2016, respectively. While the OECD principles help me sketch the scorecard, the ASEAN CG scorecard and the national codes guide me in building specific questions.

I end up with a CG scorecard composed from five categories: A) the rights of shareholders, B) equitable treatment of shareholders, C) the role of stakeholders in CG, D) disclosure and transparency, and E) the responsibilities of the board. Respectively, each category from A to E accounts for $10 \%, 15 \%, 10 \%, 25 \%$, and $40 \%$ of the total score. I follow the ASEAN CG scorecard for these weights. Questions will be developed in each category to ensure the scorecard realistically and accurately measures firms' CG practices. Each question can be supplemented by sub-questions when detailed information needs to be assessed. 
Data used for answering this CG scorecard include annual reports, articles of association, annual shareholder meeting minutes and documents (proposals, notices to call for shareholders' meetings, notarizing forms for shareholders' attorney, and others), company websites, notices from the State Securities Commission of Vietnam (SSC) about firms' violation on the securities market, and others. Then, one point will be granted to each question or each sub-question when the information of the company answers "yes" to the question. If the answers are intermediate, I give 0.5 to the questions. The score of each question is the sum of the sub-questions' scores, then the score of each category is the sum of all the questions' scores in that category.

Finally, the weighted-average score is used as the final CGS whose value ranges from 0 to 100. Yearly CGSs are recorded for each firm in the sample, but a quarterly data set is created by putting the same score (the yearly score) for all quarters within a year.

Details of the CG scorecard are provided in Appendix 1. In the following section, I will discuss in general each of the categories.

Rights of shareholders. This category ensures the rights of shareholders, including minority and foreign ones, to be protected and facilitated. Besides fundamental rights, such as the election of board members, amendments to the company's original documents, etc., well-governed companies should provide shareholders additional rights such as the approval or election of auditors, direct nomination of board members, the ability to pledge shares, and so on. I construct six questions and five sub-questions in this category.

Equitable treatment of shareholders. All shareholders of the same series of a class should be treated equally. This equitable treatment is characterized by the ability of shareholders in each series of class to carry the same rights, and to approve economic and voting rights which are negatively affected. Furthermore, it is required to ensure a proper management of conflict of interests and to protect the interests of the company and its shareholders. I develop nine questions in this category.

The role of stakeholders in corporate governance. This category emphasizes the contribution of the stakeholders, including employees, investors, creditors, customers and suppliers, and the 
environment to the success of corporations. The contribution reflects how corporations meet the rights of these stakeholders established by law or mutual agreements. Corporations should recognize that these contributions makes up their competitiveness and ultimate success. Therefore, CG, according to OECD principles, is also concerned with finding ways to encourage the stakeholders to undertake economically optimal levels of investment in specific human and physical capital. The category includes five questions.

Disclosure and transparency. Since disclosure and transparency are what investors and market participants regularly most expect for their economic decisions, they are a vital part of good CG, which should ensure timely and accurate reporting on all material matters, including the financial situation, performance, ownership, and governance of the company. A good disclosure is reasonably administrative, but not a cost burden to companies, promotes real transparency, as well as helps improve public understanding of the structure and activities, the policies and performance, and the outside relationships of firms. In my CG scorecard, this category includes nine questions and 19 sub-questions in total.

The responsibilities of the board. With regard to its responsibilities, the board should be charged with the functions of governing the enterprise and monitoring management. Moreover, the board must be able to exercise objective and independent judgment, since its responsibilities to the company are great. Examples of board responsibility include overseeing the risk management system and systems designed to ensure that the corporation obeys applicable laws, including tax, competition, labor, environmental, equal opportunity, health and safety laws. In addition, boards are expected to take due regard of, and deal fairly with, other stakeholder interests, including those of employees, creditors, customers, suppliers, and local communities. This category of my CG scorecard is constructed from 11 questions and six sub-questions.

Table 3.1 describes the structure of the CG scorecard used in this chapter. I develop five sections and 52 questions in total in the card. I calculate the CGS annually, and use the natural logarithm of this score as the independent variable. 
Table 3.1. The corporate governance scorecard structure

This table summarizes the structure of the CG scorecard. The scorecard includes five sections. Each section accounts for a certain weight in the card and is supplemented by a number of questions. Details of the scorecard are presented in Appendix 1.

\begin{tabular}{lcc}
\hline Sections & $\begin{array}{c}\text { Number of questions } \\
\text { (including sub-questions) }\end{array}$ & Weight(\%) \\
A. Rights of shareholders & 9 & 10 \\
B. Equitable treatment od shareholders & 9 & 15 \\
C. The role of stakeholders in corporate governance & 5 & 10 \\
D. Disclosure and transparency & 14 & 25 \\
E. The responsibilities of the Board & 15 & 40 \\
$\quad$ Total & 52 & 100 \\
\hline
\end{tabular}

\subsubsection{Firm characteristics and other variables}

Firm characteristics variables used as control variables in this chapter include the natural logarithm of firm total assets (LnTA); the earnings ratio (ROA), which is calculated as the net income divided by total assets; $\mathrm{PE}$ ratio $(\mathrm{PE})$, which is the ratio between the market price and the earnings rate per share; the market-to-book value (MTBV), defined as the market value of the common equity divided by the balance sheet value of the common equity; and dummy variable of high ownership concentration (OWNCON), which equals 1 if the largest shareholder of a firm holds from and above $50 \%$ of the total firm shares, and 0 otherwise.

I also include stock market liquidity as a control variable in my regression. Undoubtedly, market liquidity is related to informed trading. Specifically, informed trades reduce the market liquidity (Wong et al., 2009). Therefore, I control for stock market liquidity to address the possibility that it is a factor driving the relation between the two variables. The proxy for stock market liquidity is the Amihud measure. The Amihud measure (AM) is the average of the daily ratio of absolute stock return to dollar volume (Amihud, 2002). For the Vietnam market, I use the Vietnam dong (VND) instead of the US dollar (as used in the original measure) to compute the volume in currency. For each stock, I calculate quarterly Amihud illiquidity using the average ratio of the daily absolute return to the VND trading volume on that day during a quarter. The formula for a stock's Amihud illiquidity is defined as below: 


$$
A M_{i y}=\frac{1}{D_{i y}} \sum_{t=1}^{D_{i y}} \frac{\left|r_{i y t}\right|}{V O L D_{i y t}}
$$

where $r_{i y t}$ is the return on stock $i$ on day $t$ of quarter $y, V O L D_{i y t}$ is the corresponding daily trading volume in $\mathrm{VND}$, and $D_{i y}$ is the number of trading days for stock $i$ in quarter $y$.

Another variable used as a control variable is the daily stock trade-size (TS). The daily TS is defined as the volume in VND traded in one trading day divided by the number of trades executed on the same day. I calculate the TS daily, and obtain the quarterly TS by taking the average of the daily observations in each quarter. Theoretically, stock trade-size can also measure the stock liquidity. Then stock trade-size should be negatively correlated with the firm IAC. However, a higher stock trade-size means that it is easier for investors to enter or exit at a desired price. Firms with a higher stock trade-size are, hence, likely good approaches for investors trading on private information. I use the logarithm of TS (lnTS) in the regressions.

\subsubsection{Regression with the Fama-MacBeth procedure}

I use the Fama-MacBeth procedure to examine the relationship between firms' CG practices (proxied by CGS) and firms' informed trading level (proxied by IAC). At the same time, to adjust for standard errors, I use the Newey-West procedure (Newey and West, 1987). Then, the main regression in this chapter is designed as follow:

$$
\begin{aligned}
I A C_{i t}=\alpha_{t} & +\beta_{1 t} L n C G S_{i t}+\beta_{2 t} M T B V_{i t}+\beta_{3 t} A M_{i t}+\beta_{4 t} \ln T S_{i t}+\beta_{5 t} \ln T A_{i t} \\
& +\beta_{6 t} O W N C O N_{i t}+\beta_{7 t} R O A_{i t}+\beta_{8 t} P E_{i t}+\varepsilon_{i t},
\end{aligned}
$$

where $I A C_{i t}$ is the informed trading level of firm $i$ at quarter $t$; $L n C G S_{i t}$ is natural logarithm of firm $i$ 's corporate governance score at quarter $t$; the other variables, explained in the previous section, represent firm $i$ 's characteristics at quarter $t$.

This Fama-MacBeth regression allows $\alpha_{t}$ and $\beta_{j t}(\mathrm{j}=1,2, \ldots 8)$ to vary from time to time. The hypothesis of the relation between the IAC and CGS is $E\left(\beta_{1 t}\right)<0$. I test whether $\beta_{1 t}$ is negative 
using the mean of $\beta_{1 t}$, and adjust the standard errors using Newey-West procedure with two lags.

\subsection{Data and empirical results}

\subsubsection{Data}

The data sample starts from 2011 to 2016, and includes stocks listed in the Ho Chi Minh City Exchange (HOSE). See Appendix 2 for details on data collection. To ensure that annual reports and general shareholder meeting (GSM) related documents are collected for all firms in the sample, firms listed at HOSE after 2010 will be excluded. This constraint leaves me a sample of 227 stocks.

I collect data and compute the variables in quarterly frequency. Specifically, I calculate quarterly IACs, the Amihud measure, and stock trade-size using intraday prices retrieved from the Thompson Reuters Tick History (TRTH) database available from SIRCA. I also use this intraday data to determine the trade initiation direction.

For quarterly CGSs, I collect the annual reports, articles of association, annual shareholder meeting minutes and documents (proposals, notices to call for shareholders' meetings, notarizing forms for shareholders' attorney, and others) for each firm from their websites and the SSC (Vietnam) website, and use these documents to calculate the firms' CGSs annually. After recording the firms' yearly CGSs, I create the quarterly data set by using the yearly score for quarters within the same year. To obtain a normal distribution of the CGS, I use the logarithm of CGSs (lnCGS) in my analysis.

I collect data of firm characteristics from the WorldScope and the Datastream databases available on Thompson Reuters EIKON. In addition, I request data of large shareholder ownership from a private data company in Vietnam.

All variables are winsorized at the 1st and 99th percentiles to mitigate the influence of outliers. Table 3.2 reports the summary statistics. Panel A of Table 3.2 reports the mean, the standard deviation, the minimum, and the maximum of all variables. The variables of interest, the logarithm of corporate governance score (lnCGS), and the information asymmetry cost (IAC) are averaged 
at 4.16 and 0.55 , respectively.

Table 3.2. Descriptive statistics

${ }^{16}$ anel A reports the mean, standard deviation, minimum, and maximum of all variables during 2011 - 2016. All variables are winsorized at the 1st and 99th percentiles. The definitions of the variables are in Section 3.2. Panel B presents the CGSs at different percentiles. Panel $\mathrm{C}$ reports the firms' characteristics relative to quintiles of firms by CGS. The mean of each variable is calculated for each quintiles.

\begin{tabular}{|c|c|c|c|c|c|c|}
\hline \multicolumn{7}{|c|}{ Panel A. All variables } \\
\hline & & $\mathrm{N}$ & Mean & STD & Min & Max \\
\hline \multicolumn{2}{|l|}{$\operatorname{lnCGS}$} & 4584 & 4.16 & 0.15 & 3.75 & 4.45 \\
\hline \multicolumn{2}{|l|}{ IAC } & 4584 & 0.55 & 0.49 & 0.06 & 2.83 \\
\hline \multicolumn{2}{|l|}{ LnTA } & 4584 & 21.16 & 1.42 & 18.91 & 26.63 \\
\hline \multicolumn{2}{|l|}{ MTBV } & 4584 & 1.09 & 0.74 & 0.26 & 4.49 \\
\hline \multicolumn{2}{|l|}{$\mathrm{PE}$} & 4584 & 18.39 & 41.99 & 2.10 & 340.90 \\
\hline \multicolumn{2}{|l|}{$\mathrm{ROA}$} & 4584 & 0.06 & 0.07 & -0.07 & 0.33 \\
\hline \multicolumn{2}{|l|}{ AM } & 4584 & 0.01 & 0.03 & 0.00 & 0.19 \\
\hline \multicolumn{2}{|l|}{ OWNR } & 4584 & 35.73 & 19.12 & 5.81 & 79.70 \\
\hline \multicolumn{2}{|l|}{ LnTS } & 4584 & 17.31 & 1.19 & 14.39 & 20.23 \\
\hline \multicolumn{7}{|c|}{ Panel B. CGS's distribution } \\
\hline \multicolumn{3}{|c|}{ Percentiles } & \multicolumn{4}{|l|}{ Score } \\
\hline \multicolumn{7}{|c|}{$1 \%$} \\
\hline & & $5 \%$ & \multicolumn{4}{|l|}{3.88} \\
\hline & & $10 \%$ & \multicolumn{4}{|l|}{3.96} \\
\hline & & $25 \%$ & \multicolumn{4}{|l|}{4.07} \\
\hline \multirow[t]{5}{*}{$\operatorname{lnCGS}$} & & $50 \%$ & \multicolumn{4}{|l|}{4.17} \\
\hline & & $75 \%$ & \multicolumn{4}{|l|}{4.27} \\
\hline & & $90 \%$ & \multicolumn{4}{|l|}{4.34} \\
\hline & & $95 \%$ & \multicolumn{4}{|l|}{4.38} \\
\hline & & $99 \%$ & \multicolumn{4}{|l|}{4.45} \\
\hline \multicolumn{7}{|c|}{ Panel C. Characteristics of high (low) CGS firms } \\
\hline Quintiles & $N$ & $I A C$ & $\operatorname{LnTA}$ & $M T B V$ & $R O A$ & Amihud \\
\hline Low CGS & 917 & 0.67 & 20.73 & 0.88 & 0.06 & 0.016 \\
\hline 2 & 944 & 0.64 & 20.76 & 0.93 & 0.05 & 0.018 \\
\hline 3 & 897 & 0.58 & 21.05 & 1.03 & 0.06 & 0.014 \\
\hline 4 & 935 & 0.48 & 21.29 & 1.17 & 0.07 & 0.009 \\
\hline High CGS & 891 & 0.37 & 21.99 & 1.43 & 0.07 & 0.004 \\
\hline
\end{tabular}

Panel B of Table 3.2 reports the percentile distribution of the CGS. Ten percent of firms have lnCGS greater than 4.34 , while $10 \%$ of firms have lnCGS lower than 3.96. There exists crosssectional difference in the CGS of all firms.

Panel C of Table 3.2 reports the firms' characteristics according to firms' CGSs. I divide the firms into quintiles according to their lnCGS, and calculate the mean of the characteristics variables 
for each group. The third column of Panel $\mathrm{C}$ reports the firms' IACs according to their CGSs. I observe a clear pattern that low-CGS firms have high IAC. This means that a well-governed firm is associated with a low level of informed trading, suggesting a negative relation between the two variables.

Similarly, columns 4, 5, 6, and 7 of Panel C report the firm size, MTBV, ROA, and Amihud measure, respectively, according to their GCSs. Obviously, large firms have high lnCGS. The logarithm of total assets of the first and second CGS-groups are 20.73 and 20.76, respectively, and the numbers increase along with the quintiles. Also, firms in higher-CGS groups have higher MTBV. For example, the MTBVs increase from 0.88 to 1.43 when moving from the lowest CGSgroup to the highest-CGS group. This suggests that high-CGS firms have stocks with high market value. This is consistent with the finding by Fich and Shivdasani (2006), who claim that weak corporate governance firms exhibit lower market-to-book ratios. The pattern is the same for firms' ROAs.

Firms' Amihud measure decreases from the low-CGS firms to the high-CGS firms. This means that stocks of higher-CGS firms are more liquid. This is consistent with the finding by Ali, Liu, and $\mathrm{Su}$ (2017), who document a significant positive relationship between corporate governance quality and stock liquidity. Moreover, Karmani and Ajina (2012) suggest that firms with better corporate governance may reduce informative asymmetry and thus improve the liquidity of their stocks.

\subsubsection{Empirical results}

\subsubsection{Preliminary analysis}

In this section, I report the correlation matrix among the variables, and conduct the simple $t$-test for the differences in IACs between high- and low-CGS firms.

Table 3.3 reports the correlation coefficients among all variables. The correlation coefficient between IAC and CGS is -0.22 and statistically significant at the $1 \%$ level, suggesting a negative relation between them.

Besides, the $\operatorname{lnTA}$, ROA, MTBV, and $\operatorname{lnTS}$ are also negatively correlated with the IAC with the 
correlation coefficients of $-0.46,-0.02,-0.15$, and -0.36 , respectively, while the other variables are positively correlated with the IAC. All these coefficients are statistically significant at least at the $10 \%$ level.

Table 3.3. Correlation matrix

This table reports the Pearson correlation coefficients among the variables. All variables are winsorized at the 1 st and 99 th percentiles. $* * *$, and $* * *$ indicate statistical significance at the $10 \%, 5 \%$, and $1 \%$ level, respectively.

\begin{tabular}{|c|c|c|c|c|c|c|c|c|c|}
\hline & IAC & $\operatorname{lnCGS}$ & $\operatorname{lnTA}$ & ROA & $\mathrm{PE}$ & MTBV & $\mathrm{AM}$ & OWNR & $\operatorname{lnTS}$ \\
\hline IAC & 1.00 & & & & & & & & \\
\hline $\operatorname{lnCGS}$ & $-0.22^{* * *}$ & 1.00 & & & & & & & \\
\hline $\ln \mathrm{TA}$ & $-0.46^{* * *}$ & $0.30^{* * *}$ & 1.00 & & & & & & \\
\hline $\mathrm{ROA}$ & $-0.02^{*}$ & $0.09^{* * *}$ & $-0.19^{* * *}$ & 1.00 & & & & & \\
\hline PE & $0.05^{* * *}$ & 0.00 & $0.06^{* * *}$ & $-0.20^{* * *}$ & 1.00 & & & & \\
\hline MTBV & $-0.15^{* * *}$ & $0.26^{* * *}$ & $0.26^{* * *}$ & $0.41^{* * *}$ & $-0.04^{* * *}$ & 1.00 & & & \\
\hline AM & $0.72^{* * *}$ & $-0.14^{* * *}$ & $-0.30^{* * *}$ & $-0.11^{* * *}$ & $0.14^{* * *}$ & $-0.16^{* * *}$ & 1.00 & & \\
\hline OWNR & $0.03^{* *}$ & $0.03^{* *}$ & $0.08^{* * *}$ & $0.05^{* * *}$ & 0.00 & $0.06^{* * *}$ & $0.05^{* * *}$ & 1.00 & \\
\hline $\operatorname{lnTS}$ & $-0.36^{* * *}$ & $0.29^{* * *}$ & $0.53^{* * *}$ & $0.18^{* * *}$ & $-0.03^{* *}$ & $0.46^{* * *}$ & $-0.42^{* * *}$ & $-0.15^{* * *}$ & 1.00 \\
\hline
\end{tabular}

I next conduct $t$-tests for differences in IACs between the high- and low-CGS firms. In each year, I ascendingly sort the sample firms by their CGSs into four groups. Then, high- and low-CGS firms are defined as the fourth and first quartiles. I calculate the means of IACs for the two groups every year, and test whether the means are significantly different.

Table 3.4 reports the $t$-tests for the differences of the IACs between the high- and low-CGS firms from 2011 to 2016. In the six-year period, the informed trading level of the low-CGS firms is significantly higher than that of the high-CGS ones. For example, in 2011 the informed trading levels of high- and low-CGS firms are 0.65 and 0.56 , respectively. The difference between those two informed trading levels is 0.09 and significant at the $10 \%$ level. The pattern is similar for the following years.

Besides, the differences in IACs between the high- and low-CGS portfolios become greater and stronger overtime. For example, the differences in IACs between high- and low-CGS portfolios in 2011 and 2016 are 0.09 and 0.41 , respectively. These differences are significant at the $10 \%$ and $1 \%$ levels, respectively. The reason for this result is that while the IACs of low-CGS firms do not show a significant change in six years, those of high-CGS firms have a great decrease from 0.56 in 2011 to 0.28 in 2016 . 
Table 3.4. Informed trading levels (IACs) of high- and low-CGS firms This table reports the $t$-tests for the differences in IACs between high- and low-CGS groups. In each year, the sample firms are ascendingly sorted by their CGSs into four groups. The high- and low-CGS groups are defined as the fourth and first quartiles. The means of IACs are calculated for the high- and low-CGS groups each year. $t$ statistics are in parentheses. $*, * *$, and $* * *$ indicate statistical significance based on two-sided tests at the $10 \%, 5 \%$, and $1 \%$ level, respectively.

\begin{tabular}{ccccccc}
\hline & 2011 & 2012 & 2013 & 2014 & 2015 & 2016 \\
1. Low-CGS firms & 0.65 & 0.61 & 0.75 & 0.72 & 0.70 & 0.69 \\
$N$ & 191 & 183 & 188 & 193 & 201 & 188 \\
2. High-CGS firms & 0.56 & 0.47 & 0.41 & 0.36 & 0.35 & 0.28 \\
$N$ & 192 & 184 & 189 & 194 & 201 & 188 \\
& & & & & \\
Difference (1-2) & $0.09^{*}$ & $0.14^{* * *}$ & $0.35^{* * *}$ & $0.36^{* * *}$ & $0.35^{* * *}$ & $0.41^{* * *}$ \\
& $(1.94)$ & $(3.19)$ & $(6.14)$ & $(6.68)$ & $(6.82)$ & $(8.34)$ \\
\hline
\end{tabular}

These results build up my confidence about a negative relation between CGS and IAC.

\subsubsection{Regression results}

As the main analysis, in this section I test whether there exists a negative relation between firms' CG practices and informed trading, by regressing IACs on CGSs and control variables. The results are reported in Table 3.5.

Table 3.5 reports all the coefficients of Regression 3.5 for the full sample and the subsamples of firm size, firm level of trading frequency, and firm level of turnover ratio. The first column in Table 3.5 reports the results of the full sample. The negative coefficient on CGS is -0.11 and significant at the $5 \%$ level. For the interpretation, for example, we are considering two identical firms (e.g. in terms of firm size, market value, etc.) but the CGS of one firm (say, firm A) is $1 \%$ higher than that of the other (firm B). Then the informed trading level of firm A should be 0.11 points lower than that of firm B. As the first conclusion, firms' CG practices is negatively correlated with informed trading.

In addition, firm characteristics also explain the variation of the informed trading level across firms. The coefficients on InTA and ROA are significantly negative, meaning that large firms and firms with a high return ratio have a low level of informed trading. The coefficients on the Amihud measure is significantly positive, suggesting that liquid firms (firms with a low Amihud measure) 
have a low level of informed trading. The coefficient on $\operatorname{lnTS}$ is also significantly positive. As explained above, a higher stock trade-size means that it is easier for investors to enter or exit at a desired price. Hence, high trade-size stocks are likely good approaches for investors trading on private information. This explains the positive coefficient on lnTS. In short, firms who are large, liquid, and firms with high ROA, and low stock trade-size tend to have low IACs.

Table 3.5. Regression analysis

This table reports the results from regression 3.5. Full sample regression uses all variables in the whole sample period. Large (small) firms are firms having their total asset greater (smaller) than the sample median in each quarter. High- (low-) trading-frequency firms are firms having their trading frequency level above (below) the sample median in each quarter. Trading frequency is defined as firms' average number of transactions executed per day in a quarter. High- (low-) turnover-ratio firms are firms having their turnover ratio above (below) the sample median in each quarter. Turnover ratio is defined following Lesmond (2005), Turnover $_{i, q}=\frac{1}{D_{q}} \sum_{t=1}^{D_{q}} \frac{\text { Volume }_{i, t}}{\text { Share }_{i, t}}$, where $D_{q}$ is the number of trading days in quarter $q$, Volume $_{i, t}$ is the number of shares traded in stock $i$ on day $t$, and Share ${ }_{i, t}$ is the number of outstanding shares $i$ on day $t$. $t$ statistics are in parentheses. *,**, and *** indicate statistical significance at the $10 \%$, $5 \%$, and $1 \%$ level, respectively.

\begin{tabular}{|c|c|c|c|c|c|c|c|}
\hline \multicolumn{8}{|c|}{ Dependent variable: IAC } \\
\hline & \multirow{2}{*}{$\begin{array}{c}\text { Full } \\
\text { sample }\end{array}$} & \multicolumn{2}{|c|}{ Firm size } & \multicolumn{2}{|c|}{ Trading frequency (TF) } & \multicolumn{2}{|c|}{ Turnover ratio (TR) } \\
\hline & & Large & Small & High TF & Low TF & High TR & Low TR \\
\hline \multirow[t]{2}{*}{$\operatorname{lnCGS}$} & $-0.11^{* *}$ & $-0.23^{* * *}$ & 0.03 & $-0.15^{* * *}$ & -0.10 & $-0.10^{* *}$ & -0.13 \\
\hline & $(-2.07)$ & $(-2.71)$ & $(0.35)$ & $(-3.46)$ & $(-1.07)$ & $(-2.07)$ & $(-1.50)$ \\
\hline \multirow[t]{2}{*}{ MTBV } & 0.02 & $0.01^{* *}$ & $0.06^{* *}$ & $0.04^{* *}$ & 0.01 & $-0.07^{* * *}$ & -0.01 \\
\hline & (1.63) & $(2.01)$ & $(2.15)$ & $(2.42)$ & $(0.60)$ & $(-3.21)$ & $(-0.69)$ \\
\hline \multirow[t]{2}{*}{ AM } & $12.00^{* * * *}$ & $12.93^{* * *}$ & $12.61^{* * *}$ & $11.59^{* * *}$ & $12.95^{* * *}$ & $15.97^{* * *}$ & $10.78^{* * *}$ \\
\hline & (16.30) & (12.93) & $(12.25)$ & $(12.50)$ & (11.43) & (9.38) & (11.53) \\
\hline \multirow[t]{2}{*}{$\operatorname{lnTS}$} & $0.04^{* * *}$ & $0.02^{*}$ & $0.06^{* * *}$ & 0.01 & $0.07^{* * *}$ & $0.10^{* * *}$ & $0.07^{* * *}$ \\
\hline & $(3.44)$ & (1.84) & $(3.67)$ & $(0.67)$ & $(5.70)$ & $(6.26)$ & $(3.00)$ \\
\hline \multirow[t]{2}{*}{$\ln \mathrm{TA}$} & $-0.11^{* * *}$ & $-0.08^{* * *}$ & $-0.06^{* * *}$ & $-0.10^{* * *}$ & $-0.10^{* * *}$ & $-0.11^{* * *}$ & $-0.12^{* * *}$ \\
\hline & $(-17.81)$ & $(-15.52)$ & $(-3.12)$ & $(-10.46)$ & $(-6.35)$ & $(-1226)$ & $(-11.82)$ \\
\hline \multirow[t]{2}{*}{ OWNCON } & -0.01 & 0.00 & $-0.04^{* *}$ & -0.01 & $-0.03^{* *}$ & 0.01 & $-0.06^{* * *}$ \\
\hline & $(-1.94)$ & $(0.38)$ & $(-2.40)$ & $(-0.69)$ & $(-1.99)$ & $(1.15)$ & $(-5.83)$ \\
\hline \multirow[t]{2}{*}{ ROA } & $-0.42^{* * *}$ & $-0.46^{* * *}$ & $-0.51^{* *}$ & $-0.43^{* *}$ & $-0.32^{*}$ & $-0.58^{* * *}$ & $-0.65^{* * *}$ \\
\hline & $(-3.41)$ & $(-4.83)$ & $(-2.65)$ & $(-2.23)$ & $(-1.71)$ & $(-7.66)$ & $(-3.95)$ \\
\hline \multirow[t]{2}{*}{$\mathrm{PE}$} & -0.02 & 0.02 & -0.05 & $-0.06^{* *}$ & 0.01 & -0.01 & 0.00 \\
\hline & $(-0.32)$ & $(0.55)$ & $(-0.60)$ & $(-2.21)$ & $(0.12)$ & $(-0.59)$ & $(0.07)$ \\
\hline \multirow[t]{2}{*}{$\alpha$} & $2.35^{* * *}$ & $2.70^{* * *}$ & 0.51 & $2.83^{* * *}$ & $1.87^{* * *}$ & $1.56^{* * *}$ & $2.44^{* * *}$ \\
\hline & $(8.70)$ & $(10.51)$ & (1.43) & $(12.41)$ & (5.59) & (11.88) & (8.06) \\
\hline$N$ & 4584 & 2299 & 2285 & 2299 & 2285 & 2299 & 2285 \\
\hline$R^{2}$ & 0.624 & 0.612 & 0.584 & 0.654 & 0.593 & 0.673 & 0.644 \\
\hline
\end{tabular}

To conduct the analysis across the market, I run the regression for subsamples. Columns 2 to 7 of Table 3.5 report all the coefficients of Regression 3.5 for the subsamples of firm size (large and small), firm level of trading frequency (high and low TF), and firm level of turnover ratio (high and 
low TR). For firm size, I sort the sample firms into two groups depending on the median of their total assets every quarter, and use the high- (low-) total-asset firms across quarters to create the large (small) firm group. High- (low-) TF firms, and high- (low-) TR firms are created in the same logic, using firms' TF levels and TR levels, respectively, in the sorting exercise. I observe that only the coefficients on lnCGS of large firms, firms with a high TF and a high TR are significantly negative, but those of the other firms are not significant. For example, the coefficient of large firms is -0.23 and significant at the $1 \%$ level, while that of small firms is 0.03 and insignificant. So, the relationship between CGSs and IACs is pronounced for large firms. Similarly, the coefficient of high-TF firms is -0.15 and significant at the $1 \%$ level, compared with that of low-TF firms, which is -0.10 and insignificant. High- and low-TR firms show the same pattern. Since TF and TR measure stock liquidity, the negative relationship between the CGS and IAC is pronounced for liquid firms.

\subsubsection{A causal relationship}

After confirming the negative relationship between CGSs and IACs, I next examine whether the relationship is a causal one, in which a change in the former causes a change in the latter. Specifically, I conduct $t$-tests for the changes in CGSs and IACs of particular groups of firms after the two circulars issued by the Ministry of Finance (Vietnam) in 2012. The first circular, official numbered 121/2012/TT-BTC, revises the CG concepts and principles to publicly listed companies. The main focus of this circular is board responsibilities and disclosure and transparency requirements. The second circular, official number 52/2012/TT-BTC, gives guidance on public information announcements in the securities market. These circulars generally require a higher quality in the CG of publicly listed companies. For example, Circular 52 gives detailed guidance on which types of documents should be included in a general shareholder meeting (GSM). These documents should be delivered to shareholders at least 15 days before the meeting. This guidance did not exist in previous relative policies. Therefore, these requirements encourage companies to have their CG practices upgraded. These policy changes generate a shock to the CG practices of all firms and 
thus provide a natural experience to test how they affect firms' informed trading.

Firstly, the CGSs should remarkably increase after the circulars. To show this change in the CGS, I create the benchmark groups of firms and plot the CGSs of these groups over time. In 2011, the sample firms are sorted by their total assets, TF, or TR into two equal groups of large and small, high- and low-TF, or high- and low-TR firms depending on the sample medians of total assets, TF, or TR, respectively. These groups of firms are kept the same in six-year period, and defined as the benchmark firm groups. I report the changes in the CGSs of these benchmark groups before and after 2012 in Figure 3.1. This figure plots the average lnCGS of groups of firms according to their size, levels of TF, and levels of TR in Panels A, B, and C, respectively, from 2011 to 2016. Obviously, all firms (large and small, high and low TF, high and low TR) have their CGSs shoot up in 2012, and steadily increase there after.

Next, I conduct $t$-tests for the changes in the lnCGSs and IACs of the benchmark groups of firms after 2012. The results are reported in Table 3.6.

Table 3.6. CG practices and informed trading level after the CG policies in 2012

This table reports the changes in InCGSs and IACs of different firm characteristics after the policy changes in 2012. Panels A and B report the $t$-tests for lnCGSs and IACs, respectively. Large (small) firms are firms in the first (second) half of the sample firms by their average total assets in 2011. High- (low-) tradingfrequency (TF) firms are firms in the first (second) half of the sample firms by their average number of transactions executed on a trading day in 2011. High- (low-) turnover-ratio (TR) firms are firms in the first (second) half of the sample firms by their average turnover ratio in 2011. Since the policies are released in 2012, data in 2012 is deleted out of the test to avoid any bias in the results. A number of observations is in parentheses. *, **, and *** indicate statistical significance based on two-sided tests at the $10 \%, 5 \%$, and $1 \%$ level, respectively.

\begin{tabular}{lrrrrrrr}
\hline Panel A. lnCGS & \multicolumn{1}{c}{$\begin{array}{c}\text { Benchmark groups } \\
\text { of firm size }\end{array}$} & \multicolumn{2}{c}{$\begin{array}{c}\text { Benchmark groups } \\
\text { of firm TF }\end{array}$} & \multicolumn{2}{c}{$\begin{array}{c}\text { Benchmark groups } \\
\text { of firm TR }\end{array}$} \\
& $\begin{array}{c}\text { Full } \\
\text { sample }\end{array}$ & Large & Small & High TF & Low TF & High TR & Low TR \\
\hline 1. Before the policy & 4.02 & 4.04 & 4.00 & 4.02 & 4.01 & 4.01 & 4.04 \\
& $(765)$ & $(383)$ & $(382)$ & $(386)$ & $(379)$ & $(383)$ & $(382)$ \\
2. After the policy & 4.20 & 4.24 & 4.19 & 4.22 & 4.18 & 4.20 & 4.23 \\
& $(3084)$ & $(1438)$ & $(1380)$ & $(1539)$ & $(1545)$ & $(1350)$ & $(1468)$ \\
Difference (2-1) & $0.18^{* * *}$ & $0.20^{* * *}$ & $0.19^{* * *}$ & $0.20^{* * *}$ & $0.17^{* * *}$ & $0.19^{* * *}$ & $0.19^{* * *}$ \\
\hline Panel B. IAC & & & & & & & \\
1. Before the policy & 0.59 & 0.42 & 0.75 & 0.36 & 0.81 & 0.45 & 0.73 \\
& $(765)$ & $(383)$ & $(382)$ & $(386)$ & $(379)$ & $(383)$ & $(382)$ \\
2. After the policy & 0.53 & 0.32 & 0.70 & 0.29 & 0.76 & 0.47 & 0.54 \\
& $(3084)$ & $(1438)$ & $(1380)$ & $(1539)$ & $(1545)$ & $(1350)$ & $(1468)$ \\
Difference (2-1) & $-0.06^{* * *}-0.10^{* * *}$ & $-0.05^{*}$ & $-0.07^{* * *}$ & -0.05 & 0.02 & $-0.19^{* * *}$ \\
\hline
\end{tabular}


Panel A. CGSs of large and small firms

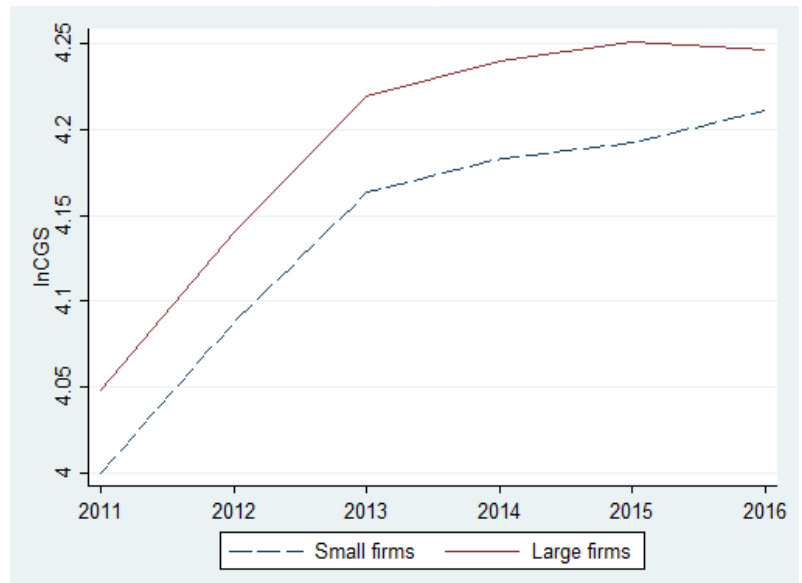

Panel B. CGSs of low- and high-TF firms

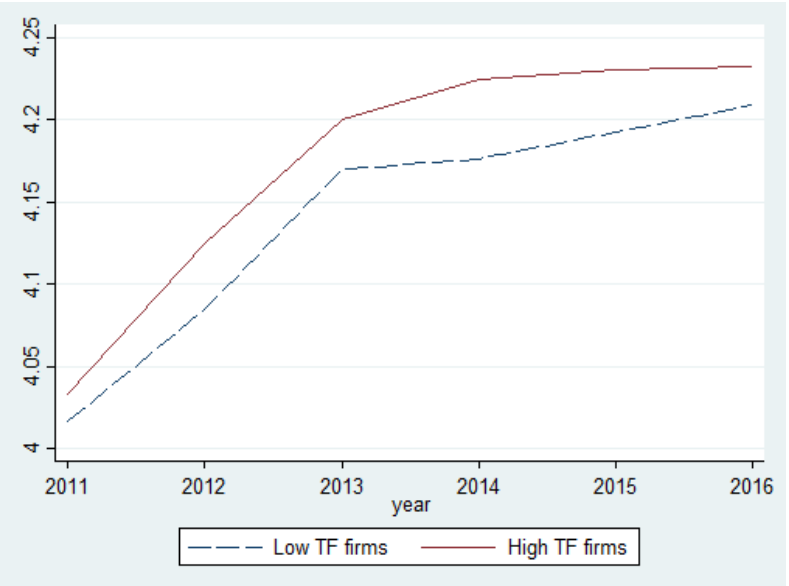

Panel C. CGSs of low- and high-TR firms

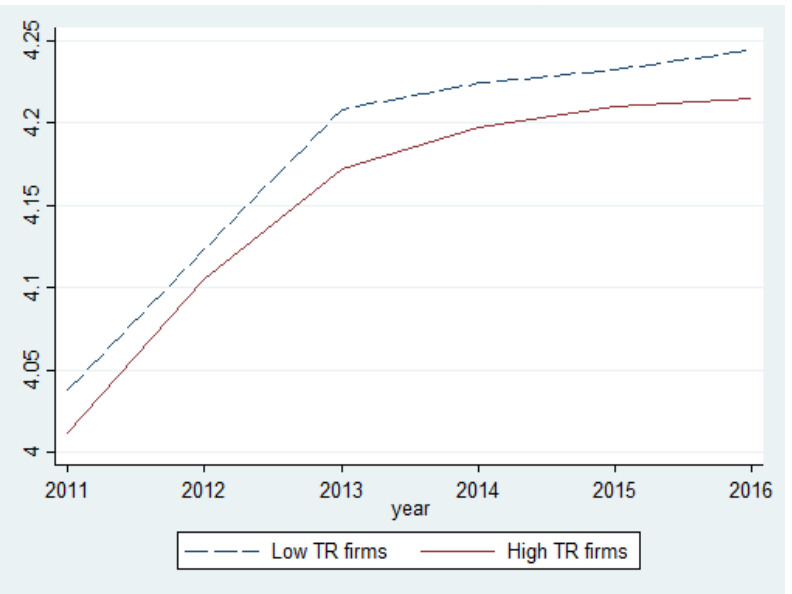

Figure 3.1. The means of CGSs of benchmark groups of firms over time

This figure plots the average CGSs of groups of firms over six years. In 2011, the sample firms are sorted by their total assets, trading frequency level, or turnover ratio into two equal groups of large and small, high- and low-trading-frequency (TF), or high- and low-turnover-ratio (TR) firms, respectively. The groups of firms are kept the same in the six-year period. The means of lnCGS of the firm groups are calculated in each year.

Table 3.6 reports the $t$-tests for the changes in the lnCGSs and IACs of the full sample and the benchmark groups of firms created above, after 2012. Panels A and B of Table 3.6 report the results for lnCGSs and IACs, respectively. As shown in the first column, after 2012, the lnCGSs of all firms increase by 0.18 , and their IACs decrease by 0.06 . These changes are significant at the $1 \%$ level.

The results of the benchmark groups of firms, shown in Columns 2 to 7 of Table 3.6, give more evidence about the increase of lnCGS and the decrease of IACs after 2012. All benchmark groups 
of firms (large and small, high and low TF, high and low TR) have their lnCGSs significantly increase, and their IACs decrease (except high-TR firms). Moreover, a greater increase in lnCGSs is associated with a greater decrease in IACs. For example, large firms have a greater increase in lnCGSs compared with small firms (0.20 versus 0.19$)$; hence, the large firms have a greater decrease in IACs $(-0.10$ versus -0.05$)$. These differences are significant at the $10 \%$ or $1 \%$ level. I observe the same pattern for high- and low-TF firms. These results suggest that the relationship between $\mathrm{CG}$ practices and informed trading level is a causal relationship, in which a change in the former causes a change in the latter.

\subsection{Corporate governance, informed trading, and the market surveillance system}

The empirical results show that there exists a negative relationship between firms' CG practices and informed trading. Moreover, it is likely a casual relationship.

The literature finds that country characteristics (e.g. legal protections for minority investors, and the level of economic and financial development) explain the variance in firms' governance ratings (Doidge et al., 2007). Moreover, the legal and regulation environments for CG and internal $\mathrm{CG}$ are complementary. A strong regulation of CG at the country level reinforces the effectiveness of internal governance at the firm level (Madhani, 2016). As a result, a change in the legal environment may drive the relationship that I am examining.

In 2013, the Vietnam government launched the market surveillance system (MSS) in HOSE. The system allows the stock exchange to oversee trading activities more effectively. In particular, this system (1) collects data from stock exchanges and the Vietnam Securities Depository (VSD); (2) monitors all trading and provides alerts and reports in the event of various types of unusual activity, including abnormal price changes, changes in volume, and breaches of the trading rules; and (3) supports data retrieval for the sake of market surveillance. ${ }^{17}$ The implementation of the

\footnotetext{
${ }^{17}$ Source: State Securities Commission of Vietnam website.
} 
MSS, then, helps strengthen the legal environment in the Vietnam market. This provides me a chance to examine how the legal environment impacts the relationship between CG practices and informed trading level.

To examine how the implementation of the MSS affects the relationship between these variables, in this section, I run the regression for the full sample and the groups of firms before and after the implementation of the MSS, and report the results in Table 3.7. This table reports the coefficients on lnCGS of Regression 3.5 for the full sample (the first column), and the groups of firms before and after the MSS implementation. To create the groups of firms before and after the MSS implementation, for example, large (small) firms are firms in the first (second) half of the sample firms by their average total assets in two years before the MSS event. The large (small) firms after the MSS event are defined the same as those before the event. The high- (low-) TF firms, and high- (low-) TR firms are formed in the same logic, using firms' average TF levels and average TR levels, respectively, in two years before the MSS implementation. Panels A and B of the table report the results before and after the MSS implementation, respectively.

In Column 1 of Table 3.7, I report the coefficients on lnCGSs before and after the MSS implementation for the full sample. Before the MSS, the coefficient is 0.06 and insignificant. But after the MSS, the coefficient is -0.16 and significant at the $1 \%$ level. Obviously, the MSS implementation affects the relationship between the variables in the way that a stronger legal environment (coming from the MSS implementation) reinforces the effectiveness of CG practices on informed trading. These results are consistent with the literature of the complementary impact of legal regimes on the internal corporate (Madhani, 2016; Doidge et al., 2007; Bergman and Nicolaievsky, 2007).

Columns 2 to 7 of Table 3.7 report the results for the groups of firms. I observe that all coefficients on lnCGSs of all firms before the MSS are not statistically significant. But after the MSS implementation, those of large, high-TF, and high-TR firms are negative and significant at the $1 \%$ level. For example, the coefficient on lnCGS of large firms before the MSS implementation is 0.07 and insignificant, but that after the MSS implementation is -0.54 and significant with a $t$-statistic 
of -4.85 . The results show that the impact of the MSS on the relationship between CG practices and informed trading is driven by large and liquid firms.

Table 3.7. Corporate governance practice and informed trading before and after the MSS

This table reports the coefficients on lnCGS in the baseline regression for large, small, liquid, and less liquid firms before and after the MSS implementation. Large (small) firms are firms in the first (second) half of the sample firms by their average total asset in two years before the MSS event. High- (low-) trading-frequency (TF) firms are firms in the first (second) half of the sample firms by their average number of transactions executed on a trading day in two years before the MSS event. High- (low-) turnover-ratio (TR) firms are firms in the first (second) half of the sample firms by their average turnover ratio in two years before the MSS event. Panel A reports the results before the implementation of the market surveillance system (MSS), from 2011 to 2012. Panel B reports the results after the implementation of the MSS, from 2014 to 2016. Controls are control variables used in Regression 3.5 . $t$ statistics are in parentheses. *, **, and *** indicate statistical significance based on two-sided tests at the $10 \%, 5 \%$, and $1 \%$ level, respectively.

\begin{tabular}{|c|c|c|c|c|c|c|c|}
\hline \multicolumn{8}{|c|}{ Dependent variable: IAC } \\
\hline & \multirow{2}{*}{$\begin{array}{c}\text { Full } \\
\text { sample }\end{array}$} & \multicolumn{2}{|c|}{ Groups of firm size } & \multicolumn{2}{|c|}{ Groups of firm $\mathrm{TF}$} & \multicolumn{2}{|c|}{ Groups of firm TR } \\
\hline & & Large & Small & High TF & Low TF & High TR & Low TR \\
\hline \multicolumn{8}{|c|}{ Panel A. Before the MSS } \\
\hline $\operatorname{lnCGS}$ & $\begin{array}{c}0.06 \\
(0.78)\end{array}$ & $\begin{array}{c}0.07 \\
(1.60)\end{array}$ & $\begin{array}{c}0.05 \\
(0.44)\end{array}$ & $\begin{array}{c}-0.01 \\
(-0.59)\end{array}$ & $\begin{array}{c}-0.07 \\
(-0.87)\end{array}$ & $\begin{array}{c}0.06 \\
(1.09)\end{array}$ & $\begin{array}{c}-0.09 \\
(-1.10)\end{array}$ \\
\hline Controls & yes & yes & yes & yes & yes & yes & yes \\
\hline$N$ & 1500 & 750 & 750 & 750 & 750 & 750 & 750 \\
\hline$R^{2}$ & 0.566 & 0.571 & 0.534 & 0.534 & 0.517 & 0.541 & 0.611 \\
\hline \multicolumn{8}{|c|}{ Panel B. After the MSS } \\
\hline $\operatorname{lnCGS}$ & $\begin{array}{c}-0.16^{* * *} \\
(-3.43)\end{array}$ & $\begin{array}{c}-0.54^{* * *} \\
(-4.85)\end{array}$ & $\begin{array}{c}0.24 \\
(1.72)\end{array}$ & $\begin{array}{c}-0.21^{* * *} \\
(-4.17)\end{array}$ & $\begin{array}{c}-0.07 \\
(-0.99)\end{array}$ & $\begin{array}{c}-0.17^{* * *} \\
(-3.26)\end{array}$ & $\begin{array}{l}-0.19^{* *} \\
(-2.08)\end{array}$ \\
\hline Controls & yes & yes & yes & yes & yes & yes & yes \\
\hline$N$ & 2331 & 1166 & 1165 & 1166 & 1165 & 1166 & 1165 \\
\hline$R^{2}$ & 0.665 & 0.672 & 0.631 & 0.583 & 0.655 & 0.612 & 0.720 \\
\hline
\end{tabular}

\subsection{Corporate governance and cumulative abnormal returns}

In this section, I calculate the cumulative abnormal returns (CARs) around financial statement announcements, and run $t$-tests for the differences in the CARs of high- and low-CGS firms. If corporate governance helps monitor informed trading, the absolute values of CARs around financial announcement dates should be lower for firms with higher CGS.

To begin with, I collect all available quarterly financial statement announcements in which the earnings per share (EPS) are reported, from 2011 to 2016. I divide the announcements into two groups: good news announcements and bad news announcements. Good (bad) news announce- 
ments include announcements which imply a positive (negative) earnings surprise (EPS surprise). The EPS surprises are defined as follows:

$$
E P S \text { surprise }_{i, q, y}=E P S_{i, q, y}-E P S_{i, q, y-1},
$$

where $E P S_{i, q, y}$ is the earnings per share of firm $i$ in quarter $q$, year $y$, and $E P S_{i, q, y-1}$ is the earning per share of firm $i$ in quarter $q$, year $(y-1)$.

Hence, a good news announcement is associated with a positive EPS surprise, and vice versa. Then, for each announcement $q$, I calculate the n-day window cumulative abnormal returns $\left(C A R_{i, q}(-n, n)\right)$ for firm $i$. For example, $C A R_{i, q}(-2,2)$ represents the cumulative abnormal return of firm $i$ at quarter $q$ in the two-day window around the announcement date.

Before calculating $C A R_{i, q}(-n, n)$, I first calculate the daily abnormal return through the CAPM model:

$$
A R_{i t}=r_{i t}-\left[r_{f t}+\beta_{i}\left(r_{m t}-r_{i t}\right)\right]
$$

where $A R_{i t}$ is the abnormal return for firm $i$ in day $t ; r_{i t}$ is the return for firm $i$ in day $t ; r_{f t}$ is the risk-free rate in day $\mathrm{t} ; r_{m t}$ is the average return of all firms in the market for day $\mathrm{t}$; and $\beta_{i}$ is the systematic risk of firm $i$ estimated by the OLS regression based on the market model using the returns from 252 days before a particular financial statement announcement $q$, but excluding the returns in the 15 days surrounding each of the previous announcements.

Then, $C A R_{i, q}(-n, n)$ is calculated to measure the market reaction to the financial statement announcements using the following equation:

$$
C A R_{i, q}(-n, n)=\sum_{t=-n}^{t=n}\left(A R_{i t}\right), \quad n=1,2, \ldots
$$

where $C A R_{i, q}(-n, n)$ is the n-day window cumulative abnormal return for firm $i$ around the financial statement announcement $q, t=0$ at the announcement date, and $A R_{i t}$ is the abnormal return for firm $i$ in day $t$ calculated in the previous equation.

Finally, for each type of announcement (good news or bad news), I calculate the average 
$C A R(-n, n)$ from the $C A R_{i, q}(-n, n)$ across firms for each group of high- and low-CGS firms, and test whether the average $C A R(-n, n)$ is significantly different between the high- and low-CGS firms.

Table 3.8 reports the $t$-tests for the differences in average $C A R(-n, n)$ of high- and low-CGS firms. I report the results for the good news announcements in Panel A of the table, and the results for the bad news announcements in Panel B. For the good news announcements, the CARs of high-CGS firms are statistically significantly lower than those of low-CGS firms. For example, the CARs of high- and low-CGS firms in the three-day window CAR $(-3,3)$ are $0.6 \%$ and $1.3 \%$, respectively, and both are significant at the $1 \%$ level. The difference between these two CARs is $0.7 \%$ and significant at the $5 \%$ level.

Similarly, for the bad news announcements, although all CARs are negative, the absolute values of the CARs of high-CGS firms remain statistically significantly lower than those of low-CGS firms. These results, again, confirm the negative relation between firms' CG practices and informed trading level.

Table 3.8. Cumulative abnormal returns (CAR) of high- and low-CGS firms around earnings announcements

This table reports the average CARs of high- and low-CGS firms, and the $t$-tests for the differences in the average CARs between high- and low-CGS firms for the goods news and bad news quarterly financial announcements. CARs are the cumulative abnormal returns in different daily windows around the announcement dates, calculated in Equation 3.8. Good (bad) news announcements include announcements which is associated with a positive (negative) earning surprise (EPS surprise). The EPS surprises are defined as $E P S$ surprise $_{i, q, y}=E P S_{i, q, y}-E P S_{i, q, y-1}$, where $E P S_{i, q, y}$ is the earnings ratio per share of firm $i$ in quarter $q$, year $y$, and $E P S_{i, q, y-1}$ is the earnings ratio per share of firm $i$ in quarter $q$, year $(y-1)$. High(low-) CGS firms are firms in the first (fourth) quartile of the sample firms by their CGSs in each quarter. $*$, **, and *** indicate statistical significance based on two-sided tests at the $10 \%, 5 \%$, and $1 \%$ level, respectively.

\begin{tabular}{lcccccc}
\hline & $\mathrm{N}$ & CAR $(-1,+1)$ & $\mathrm{CAR}(-2,+2)$ & $\mathrm{CAR}(-3,+3)$ & $\mathrm{CAR}(-5,+5)$ & $\mathrm{CAR}(-7,+7)$ \\
\hline Panel A. Good news & & & & & & \\
1. Low CGS firms & 837 & $0.006^{* * *}$ & $0.011^{* * *}$ & $0.013^{* * *}$ & $0.011^{* * *}$ & $0.010^{* * *}$ \\
2. High CGS firms & 832 & $0.005^{* * *}$ & $0.007^{* * *}$ & $0.006^{* *}$ & $0.004^{*}$ & 0.002 \\
$\quad$ Differences $(1-2)$ & & 0.001 & 0.004 & $0.007^{* *}$ & $0.007^{*}$ & $0.008^{* *}$ \\
& & & & & & \\
Panel B. Bad news & & & & & & \\
1. Low CGS firms & 905 & $-0.006^{* * *}$ & $-0.012^{* * *}$ & $-0.014^{* * *}$ & $-0.019^{* * *}$ & $-0.023^{* * *}$ \\
2. High CGS firms & 892 & $-0.003^{* * *}$ & $-0.006^{* * *}$ & $-0.008^{* * *}$ & $-0.012^{* * *}$ & $-0.016^{* * *}$ \\
$\quad$ Differences (1-2) & & $-0.003^{* *}$ & $-0.006^{* * *}$ & $-0.006^{* *}$ & $-0.007^{* *}$ & $-0.007^{*}$ \\
\hline
\end{tabular}




\subsection{Conclusion}

On the negative side, informed trading reduces market liquidity and generally involves insiders' trades in which managers trade for their own benefit at the expense of shareholders. On the other hand, CG can protect outside investors against the expropriation of insiders. As a result, a firm with better CG practices is associated with a lower level of informed stock trading.

In this chapter, I investigate the relationship between CG practices and informed trading. I measure firms' CG practices using a self-constructed CG scorecard, and estimate firms' informed trading level using the MRR model. Using data of firms listed in the Ho Chi Minh Stock Exchange, I find a negative relationship between the two variables, and pronounced for large and liquid firms.

In 2012, the government issued two circulars requiring an upgrade for the CG practices of public firms. These CG policies generated a shock to CG practices, increasing firms' CGSs. Analyzing the changes of CG practices and informed trading level around the circulars' event, I find that their negative relationship is a causal one, in which a change in the CG practices causes a change in the informed trading.

In 2013, the government launched the market surveillance system (MSS) that allows them to oversee trading activities more effectively. This provides a chance to examine how the legal environment impacts the relationship between $\mathrm{CG}$ practices and informed trading. The analysis shows that a stronger legal environment reinforces the effectiveness of CG practices on informed trading. Moreover, the impact of the MSS on the relationship between CG practices and informed trading is driven by large and liquid firms.

I finally use CARs around earnings announcements as another proxy of informed trading and document the same finding that a better level of firms' CG practices is associated with a lower level of informed trading. 


\section{Chapter 4}

\section{Are Foreign Investors Informed at the Vietnam Stock Market?}

\subsection{Introduction}

Foreign investment and international capital flow have been discussed for decades. In securities markets, foreign investment not only has no destabilizing effect (Choe, Kho, and Stulz, 1999) but also has positive effects on the markets. In particular, the literature documents the positive effects of institutional foreign investment on firms' performance in the long term. For example, Bena, Ferreira, Matos, and Pires (2017), using the data of 30 countries, find that foreign institutional ownership fosters long-term investment in tangible, intangible, and human capital, and leads to significant increases in innovation output. Similarly, Dyck, Lins, Roth, and Wagner (2019), using the data of 41 countries, find a causal positive relationship between institutional ownership and the environmental and social performance of firms. These findings support the fact that foreign and independent institutions are involved in monitoring corporations worldwide (Ferreira and Matos, 2008).

To the extent of the informativeness of foreign investors, the literature gives mix conclusions on whether foreign or domestic investors have an information advantage. Some studies document 
the information advantage of local investors. For example, US money managers and analysts who are geographically closer to the headquarters of a firm seem to have an information advantage (Coval and Moskowitz, 2001; Malloy, 2005; Baik, Kang, and Kim, 2010), or local analysts have an information advantage over foreign analysts in making earnings forecasts (Bae, Stulz, and Tan, 2008). In contrast, other authors find that foreign investors who participate in a market can actually be better informed than local investors (Froot, O'Connell, and Seasholes, 2001; Bailey, Mao, and Sirodom, 2007). A recent international study by Ferreira, Matos, Pereira, and Pires (2017) concludes that only domestic institutions show a trading pattern consistent with an information advantage. This study also finds that foreign institutions perform as well as local institutions on average.

Even though they do or do not have an information advantage over local investors, what are foreign investors informed about? Are they informed about firms' future performance which presents the fundamental value of firms? In this chapter, I investigate whether foreign investors at the Vietnam stock market are informed about firms' future performance. I use the deviation of foreign investor holding from the expected level to measure the information obtained by foreign investors. I regress the foreign investor holding on its lag and the regressors which present firms' characteristics preferred by foreign investors, and obtain the residuals. I define the residuals as the abnormal foreign investor holding (AFH). This represents the foreign investor holding unexplained by the regressors and measures the new information of foreign investors.

Then, I regress firms' future performance on the AFH and firm characteristics variables. In the main regression, given $t$ as the current quarter, I regress the Tobin's q next quarters $\left(\mathrm{q}_{t+k}\right.$, $\mathrm{k}=1,2, \ldots \mathrm{n})$ on the $\mathrm{AFH}\left(\mathrm{AFH}_{t}\right)$ and the control variables current quarter. The results show that the AFH is positively correlated with firm performance in the next four quarters (the following one year) after controlling for firm characteristics. However, at the fifth quarter $(t+5)$, the correlation becomes insignificant. This result is consistent even when I use different variables to proxy for firms' performance, such as the market-to-book ratio (MTBV) or ROA ratio.

I conduct the subsample analysis and run the main regression for large, small, liquid, less liquid 
firms, firms with or without large foreign investors, and firms listed at the Ho Chi Minh Exchange (HOSE) or Hanoi Exchange (HNX). I find that the relationship is pronounced for large and liquid firms, firms with large foreign investors, and firms listed at HOSE. It is a fact that HOSE is more active than HNX, as shown in Chapter 1. Then, the relationship seems to be strong in active markets.

A question arises following these findings, namely: If the current $\mathrm{AFH}$ is informed about firms' performance, does it predict stock price changes in the near future? I address the question by regressing the stock returns next quarters $\left(\mathrm{r}_{t+k}, \mathrm{k}=1,2, \ldots \mathrm{n}\right)$ on the AFH current quarter $\left(\mathrm{AFH}_{t}\right)$. The result shows that the AFH is significantly positively correlated with stock returns in the next three quarters. For example, a $1 \%$ increase in $\mathrm{AFH}$ in the current quarter is associated with a $0.006 \%$ increase in the daily stock return next quarter. Economically, this informativeness of the AFH could be a source of profits for foreign investors.

In the robustness test, I regress firm performance on the changes of foreign investor holding as another measure of the information obtained by foreign investors. The changes in the level of investor ownership forecast stock returns better than the last period's level of the investor ownership do if the relationship between the investor ownership and returns is driven by any information (Gompers and Metrick, 2001). Therefore, the changes of foreign ownership can be defined as the part which is explained by the information advantage. Then, if foreign investors are informed about firms, it is expected that the changes in foreign ownership are correlated with firm performance. The results in this robustness test are consistent with the results in the main model, although they are a little weaker.

This study contributes to the literature by examining the extent to which foreign investors are informed about firms. Studies find that institutional foreign investors foster firm performance in the longterm (Dyck et al., 2019; Ferreira et al., 2017; Gul, Kim, and Qiu, 2010; Ferreira and Matos, 2008; Bena et al., 2017; Dyck et al., 2019). Other studies conclude that foreign investors seem to have less of an information advantage than local investors (Coval and Moskowitz, 2001; Malloy, 2005; Baik et al., 2010), but on average they earn the same (Ferreira et al., 2017). However, little 
study has examined which information foreign investors may be informed about so that they could perform as well as locals do. This chapter documents that foreign investors are informed about firm performance in the shortterm (within one year). Besides, abnormal foreign investor holding predicts the stock prices in the following three quarters. These results suggest that foreign investors are informed about firms up to a one-year period.

The rest of the chapter is organized as follows: Section 2 explain the study process. Section 3 discusses the empirical results. Section 4 presents the profitability channel for foreign investors. Section 5 gives the robustness test. Section 6 concludes.

\subsection{The study process}

To address the research question, I first estimate abnormal foreign investor holding (AFH) using a foreign ownership regression, and then I regress firms' future performance on the AFH and firm characteristics variables with a panel regression. Each regression of the study process is displayed below.

\subsubsection{The foreign ownership regression}

The foreign ownership regression is a regression of foreign investor ownership (FO) on its first lag and the regressors, which present firm characteristics preferred by foreign investors. The FO represents the total holds of foreign investors in percentage for a firm at a quarter. I use this FO to estimate the AFH in an attempt to measure the new information of foreign investors. Specifically, the foreign ownership regression helps measure the expected level of the FO. Then, the residuals of the regression which deviate from the expected level are unexplained by the regressors. Hence, the residuals measure the information obtained by foreign investors. I define the residuals as the AFH.

The literature has documented that foreign investors on securities markets generally prefer large firms, firms with low unsystematic risk and low leverage, firms paying low dividends, and firms 
with large cash positions on their balance sheets (Kang and Stulz, 1997; Dahlquist and Robertsson, 2001). Moreover, market liquidity and presence in international markets seem to characterize foreign holdings better than firm size alone (Dahlquist and Robertsson, 2001). I use all these variables and the first lag of FO as the regressors in the regression. The regression is as follows:

$$
\begin{aligned}
F O_{i t}=\lambda_{0} & +\lambda_{1} F O_{i, t-1}+\lambda_{2} I D V O L_{i t}+\lambda_{3} F T S E_{i t}+\lambda_{4} \operatorname{lnMV}_{i t}+\lambda_{5} \text { Leverage }_{i t}+\lambda_{6} \text { Amihud }_{i t} \\
& +\lambda_{7} \text { DPS }_{i t}+\lambda_{8} \text { Cash }_{i t}+\text { Qut }_{t}+v_{i t},
\end{aligned}
$$

where $F O_{i t}$ is the foreign ownership for firm $i$ at quarter $t, I D V O L$ is idiosyncratic risk, FTSE is the firm presence in the international market, $\ln M V$ is the logarithm of the firm market value of equity, Leverage is the firm leverage, Amihud is the stock liquidity, DPS is the dividend per share, and Cash is the cash holding ratio. The calculation for these variables is explained below. I relax firm fixed effects in this model because firm fixed effects in a dynamic panel model may cause biased coefficients (Flannery and Hankins, 2013). Instead, I control for only time fixed effects $Q u t_{t}$, and standard errors are clustered at the firm-quarter level.

For the calculation of the variables in this model, first the idiosyncratic risk (IDVOL) is defined as the unsystematic risk estimated for each stock in each quarter under the three-factor Fama and French model (Fama and French, 1993), using data during the sample period, 2009-2018. Specifically, the IDVOL is the standard deviation of daily residuals from the three-factor model.

Second, I use FTSE Vietnam Index inclusion as a proxy for the firm presence in the international market. The FTSE Vietnam Index is one index in the FTSE Vietnam Index Series, ${ }^{18}$ which are the comprehensive and complementary series that provide international investors with a more accurate presentation of the performance of the Vietnam market. In particular, the indices take into account the shares available to international investors when selecting index constituents, and provide a tradable and broader benchmark with which to measure the performance of the Vietnam market. Thus, the stock addition to the FTSE Vietnam Index could be associated with an

\footnotetext{
${ }^{18}$ More information can be found at https://www.ftserussell.com/
} 
increase in foreign ownership. I use a dummy variable FTSE to express this firm characteristic. Specifically, FTSE equals 1 if firms are included in the FTSE Vietnam Index in a quarter, and 0 otherwise.

Meanwhile, I measure the stock illiquidity using the Amihud measure estimated from the model by Amihud (2002). The market value of equity (MV) is the share price multiplied by the number of ordinary shares in issue. The firm leverage (Leverage) is the ratio of firm total debts divided by firm total assets. The dividend per share (DPS) is the anticipated payment over the following 12 months, calculated on a rolling 12-month basis and displayed in 1,000 VND. Finally, the cash holding ratio (Cash) represents money available for use in a normal operation scaled by total assets.

\subsubsection{The main regression}

After estimating the AFH, I regress the firm performance next quarters on the AFH and the firm characteristics variables at the current quarter. The regression is defined as below:

$$
\begin{aligned}
\text { performance }_{i, t+k}=\alpha & +\beta_{1}^{k} \text { AFH } H_{i, t}+\beta_{2}^{k} \ln T A_{i t}+\beta_{3}^{k} \text { Leverage }_{i t}+\beta_{4}^{k} \operatorname{lnAge} e_{i t}+\beta_{5}^{k} C A P E X_{i t} \\
& +\beta_{6}^{k} S G A_{i t}+\beta_{7}^{k} \text { Close }_{i t}+F_{i}+Q u t_{t}+\varepsilon_{i t},
\end{aligned}
$$

where performance is one of the three firm performance variables, including Tobin's q, MTBV, or ROA. performance t $_{t+k}$ represents the firm performance variables at $k$ quarter ahead. Given $t$ as the current quarter, then $k=1,2, . . n$. $A F H$ is abnormal foreign investor holding measured by the residuals from Regression 4.1. InTA, Leverage, InAge, CAPEX, SGA, and Close are control variables and explained below. Firm fixed effects and quarter fixed effects are represented by $F_{i}$ and $Q u t_{t}$, respectively. Standard errors are clustered at the firm-quarter level.

For the firm performance measures, I use three different proxies: Tobin's q ratio (q), the marketto-book ratio (MTBV), and ROA ratio. I follow Bena et al. (2017) to calculate the Tobin's q ratio, that is total assets plus market value of equity minus book value of equity divided by total assets. The MTBV is the market value of equity divided by the book value of equity. The ROA ratio is calculated as the operating income divided by total assets. These ratios are displayed in percentages 
in the chapter.

The control variables include firm size, leverage, age, capital expenditure, selling and general administrative expenses, and insider ownership. The firm size is represented by the logarithm of firm total assets (lnTA). The firm leverage (Leverage) is the ratio of firm total debts divided by firm total assets. For firm age, I calculate month ages of the sample firms at the end of each quarter. The variable used in the regression is the logarithm of month ages (lnAge). Capital expenditure (CAPEX) and selling and general administrative expenses (SGA) are both scaled by firm total assets. And insider ownership (Close) is measured by the fraction of insider ownership.

In this regression, I focus on $\beta_{1}^{k}$ to examine whether the AFH has any correlation with the firm future performance. In the baseline analysis, I repeat Equation (4.2) from k equal to 1 onward. The empirical results for these regressions are reported in the next section.

\subsection{Data and Empirical results}

\subsubsection{Data}

The data sample is from 2009 through 2018 with quarterly frequency. I include all available firms listed in the Ho Chi Minh Exchange and Hanoi Exchange. This leaves me a sample of 612 firms for the 10-year period.

I collect data for the calculation of firm performance and firm characteristics from the Worldscope and Datastream databases available in Thomson EIKON. These data include firm market value of equity, book value of equity, market-to-book value, operating income, total assets, total debts, stock daily-adjusted close prices, daily trading volume, DPS, cash, capital expenditure, selling and general administrative expenses, shareholdings of insiders, and risk-free rate (the Government one-year zero bond yield). See Appendix 2 for details of data collection and the definition of the data.

For firm ages, I collect the dates of the first listing days for all firms listed in HOSE and HNX, and calculate the ages in months at the end of each quarter. The variable used in the regression is 
the logarithm of month age.

Table 4.1. Descriptive statistics

This table reports the descriptive statistics for variables used in the chapter. Data are collected quarterly from 2009 to 2018 for all firms listed in the Ho Chi Minh and Hanoi Exchanges. Foreign ownership $(F O)$ is the shareholding of all foreign investors in a firm, displayed in percentages. This FO is collected at the last trading day of each quarter. $A F H$ is the residuals from Equation (4.1), named as abnormal foreign investor holding. Tobin's q, MTBV, and ROA are displayed in percentages. Market value of equity $(M V)$, displayed in $\times 10^{12}$ of VND, is the share price multiplied by the number of ordinary shares in issue (adjusted for new issues or capital changes). $r$ is the average of daily stock returns, displayed in percentages. In sale is the logarithm of net sales. DPS isthe anticipated payment over the following 12 months displayed in 1,000 VND. The other variables are explained in Section 2. All variables are winsorized at the 1st and 99th percentiles, except the dummy variable.

\begin{tabular}{|c|c|c|c|c|}
\hline \multicolumn{5}{|c|}{ Panel A. Variables } \\
\hline & $\mathrm{N}$ & Mean & Median & STD \\
\hline FO & 14158 & 11.00 & 4.47 & 14.23 \\
\hline AFH & 14158 & 0.00 & -0.13 & 2.41 \\
\hline Tobin's q & 14158 & 109.46 & 97.34 & 50.67 \\
\hline MTBV & 14158 & 111.93 & 89.00 & 82.08 \\
\hline ROA & 13975 & 7.83 & 6.31 & 9.36 \\
\hline $\mathrm{r}$ & 13479 & 1.42 & 2.39 & 44.39 \\
\hline $\operatorname{lnMV}$ & 14158 & 12.61 & 12.44 & 1.68 \\
\hline $\operatorname{lnTA}$ & 14158 & 20.46 & 20.40 & 1.50 \\
\hline Leverage & 14158 & 0.23 & 0.22 & 0.19 \\
\hline IDVOL & 14158 & 0.03 & 0.02 & 0.01 \\
\hline $\ln A g e$ & 14158 & 3.99 & 4.20 & 0.80 \\
\hline Amihud & 14158 & 0.01 & 0.00 & 0.01 \\
\hline CAPEX & 14158 & 0.05 & 0.02 & 0.07 \\
\hline SGA & 14158 & 0.92 & 0.31 & 19.60 \\
\hline Close & 14158 & 0.51 & 0.55 & 0.26 \\
\hline Cash & 14158 & 0.09 & 0.05 & 0.11 \\
\hline ln_sale & 14158 & 18.77 & 18.79 & 1.62 \\
\hline DPS & 14158 & 0.90 & 0.77 & 0.90 \\
\hline \multicolumn{5}{|c|}{ Panel B. Dummy variable - FTSE Vietnam index inclusion } \\
\hline & \multicolumn{2}{|c|}{ Number of } & \multirow{2}{*}{\multicolumn{2}{|c|}{$\begin{array}{l}\text { Number of } \\
\text { instituents } \\
\text { (year end) }\end{array}$}} \\
\hline Year & $\begin{array}{r}\text { Inclusion } \\
\text { (durin }\end{array}$ & $\begin{array}{l}\text { Exclusion } \\
\text { he year) }\end{array}$ & & \\
\hline 2009 & 2 & 5 & \multicolumn{2}{|c|}{27} \\
\hline 2010 & 17 & 10 & \multicolumn{2}{|c|}{35} \\
\hline 2011 & 3 & 10 & \multicolumn{2}{|c|}{28} \\
\hline 2012 & 3 & 5 & \multicolumn{2}{|c|}{23} \\
\hline 2013 & 3 & 4 & \multicolumn{2}{|c|}{22} \\
\hline 2014 & 4 & 4 & \multicolumn{2}{|c|}{22} \\
\hline 2015 & 5 & 7 & \multicolumn{2}{|c|}{20} \\
\hline 2016 & 11 & 1 & \multicolumn{2}{|c|}{30} \\
\hline 2017 & 7 & 12 & \multicolumn{2}{|c|}{25} \\
\hline 2018 & 6 & 6 & \multicolumn{2}{|c|}{25} \\
\hline
\end{tabular}

Data for the FTSE Vietnam Index is from the FTSE Russell Client Service. FTSE Russell Client Service provides the list of the constituents of the FTSE Vietnam Index in 2009 from which 
I track the changes of the constituents with the quarterly index reviews published on their website.

The last data are for foreign investor ownership. I requested this ownership data from a private data company in Vietnam. The foreign investor ownership is the total holdings of foreign investors for a firm in a quarter, collected at the last trading day of each quarter and displayed in percentages.

Table 4.1 reports the descriptive statistics of all variables used in the chapter. Panel A of the table reports the means of the variable used, together with the medians and the standard deviations. For example, the FO averages at $11 \%$, and its median and standard deviation are $4.47 \%$ and $14.23 \%$, respectively. As the dependent variables, Tobin's q and MTBV are greater than 100\%, representing an increasing market. Panel B of Table 4.1 reports the dummy variable FTSE Vietnam index inclusion. This variable represents the presence of firms in the international market, used in estimating the AFH.

For more information about FO, Figure 4.1 reports the histogram of FO with the column width of $1 \%$. The histogram is skewed right, showing that most of the foreign investors are small. Specifically, the first column of the histogram shows that about $30 \%$ of foreign ownership comes from investors who hold at or less than $1 \%$ of total firm shares. Similarly, columns 1 and 2 together show that nearly $40 \%$ of foreign investment is from investors who hold at or less than $2 \%$ of total firm shares.

\subsubsection{Abnormal foreign investor holding and firm performance}

\subsubsection{The baseline results}

In this section, I first report the estimation of AFH using Regression 4.1, and then investigate whether AFH and firms' future performance are correlated using Regression 4.2.

Table 4.2 reports the results of Regression 4.1 with all coefficients on the variables. The quarterly FO in the Vietnam market strongly depends on its last quarter level. The coefficient on the first lag of the FO is nearly equal to 1 and significant at the $1 \%$ level. Hence, an increase in the last-quarter FO definitely predicts an increase in the current-quarter FO. Also, the FO is significantly positively correlated with $\ln \mathrm{MV}$, meaning that foreign investors prefer firms having a high 


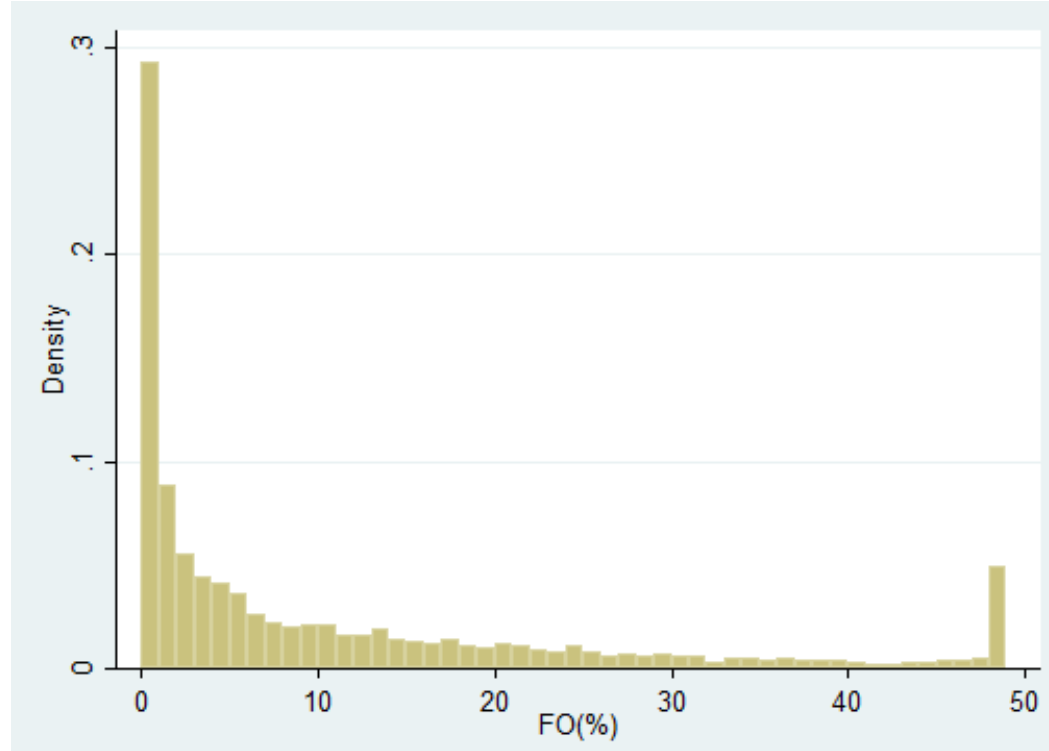

Figure 4.1. The histogram of foreign ownership

This figure plots the histogram of foreign ownership with the column width of $1 \%$. Each column of the histogram presents the frequency of the FO at every $1 \%$ interval of the ownership. The data are winsorized at the 1st and 99th percentiles. Foreign ownership is calculated in percentages.

market value of equity (large firms).

Besides, the FO is significantly negatively correlated with FTSE, IDVOL, DPS, and firm leverage. For instance, the coefficient on IDVOL is -7.86 and significant at the $1 \%$ level. The foreign investors obviously prefer firms standing out of the FTSE Vietnam Index, and firms with low idosyncratic risk, low DPS, and low leverage. One possible explanation for the negative correlation between the FO variable and the FTSE variable (the inclusion of stocks in the FTSE Vietnam Index) is that there is a limited chance for small investors to surf on the information advantage with the constituents of the FTSE Vietnam Index who are under careful watch from this international institution. And almost foreign investors in the Vietnam market are small as shown in Figure 4.1.

However, the stock market liquidity and the cash position on the firm balance sheets have no significant effect on investing decisions of the foreign investors.

The residuals from Regression 4.1, as explained before, will be used as a proxy for the abnormal foreign investor holding (AFH). This new variable obviously has a distribution with a mean of 0 (shown in Panel A of Table 4.1). 
Table 4.2. Estimating the informed foreign ownership

This table reports the coefficients for Regression 4.1. The residuals from this regression are defined as the abnormal foreign investor holding. The variables are explained in Section 4.2. The subscript $t$ indicates the current quarter. Standard errors are clustered at the firmquarter level. $t$-statistics in the parentheses. ${ }^{*},{ }^{* *},{ }^{* * *}$ indicate statistical significance at the $10 \%, 5 \%$, and $1 \%$ levels, respectively.

\begin{tabular}{lc}
\hline & $\mathrm{FO}_{t}$ \\
$\mathrm{FO}_{t-1}$ & $0.99^{* * *}$ \\
& $(421.46)$ \\
$\mathrm{FTSE}_{t}$ & $-0.26^{*}$ \\
& $(-1.67)$ \\
IDVOL $_{t}$ & $-7.86^{* * *}$ \\
& $(-3.81)$ \\
Amihud $_{t}$ & 0.97 \\
& $(0.46)$ \\
DPS $_{t}$ & $-0.08^{* *}$ \\
& $(-2.35)$ \\
Cash $_{t}$ & 0.09 \\
& $(0.23)$ \\
lnMV & \\
& $0.08^{* * *}$ \\
Leverage $_{t}$ & $(3.88)$ \\
& $-0.53^{* * *}$ \\
$\alpha_{t}$ & $(-3.09)$ \\
& $-0.96^{* * *}$ \\
Quarter fixed effects $_{N}$ & $(-4.46)$ \\
$R^{2}$ & yes \\
\end{tabular}

The first analysis for the relationship between $\mathrm{AFH}$ and future firm performance is from the correlation matrix. Table 4.3 reports the correlation coefficients among the variables. I observe that the correlation coefficient between the AFH current quarter and Tobin's q next quarter (lead1_q) is positive and significant at the $1 \%$ level. Noticeably, the correlation between AFH and the other two proxies of firm performance, MTBV and ROA, is also positive and significant with similar coefficients.

Moreover, I report more evidence of the positive correlation between AFH and firm performance in Figure 4.2. This figure shows the fitted lines of the AFH versus the three proxies for firm performance. Panels A, B, and C of Figure 4.2, respectively, present the fitted lines of the AFH current quarter versus Tobin's q, MTBV, and ROA next quarter. All the fitted lines slope upward, suggesting that AFH and future firm performance are positively correlated.

In view of these positive results, I regress the $\mathrm{AFH}$ on the future firm performance using Re- 
Table 4.3. Correlation matrix

This table reports the $t$-test for the Pearson correlation coefficients among the variables. $A F H$ is the abnormal foreign investment, estimated as the residuals from Equation (4.1). Lead 1 _ represents the respective variables at one quarter ahead. The variables are explained in Section 4.2. All variables are winsorized at the 1st and 99th percentiles before the test. ${ }^{*},{ }^{* *},{ }^{* * *}$ indicate statistical significance at the $10 \%, 5 \%$, and $1 \%$ levels, respectively.

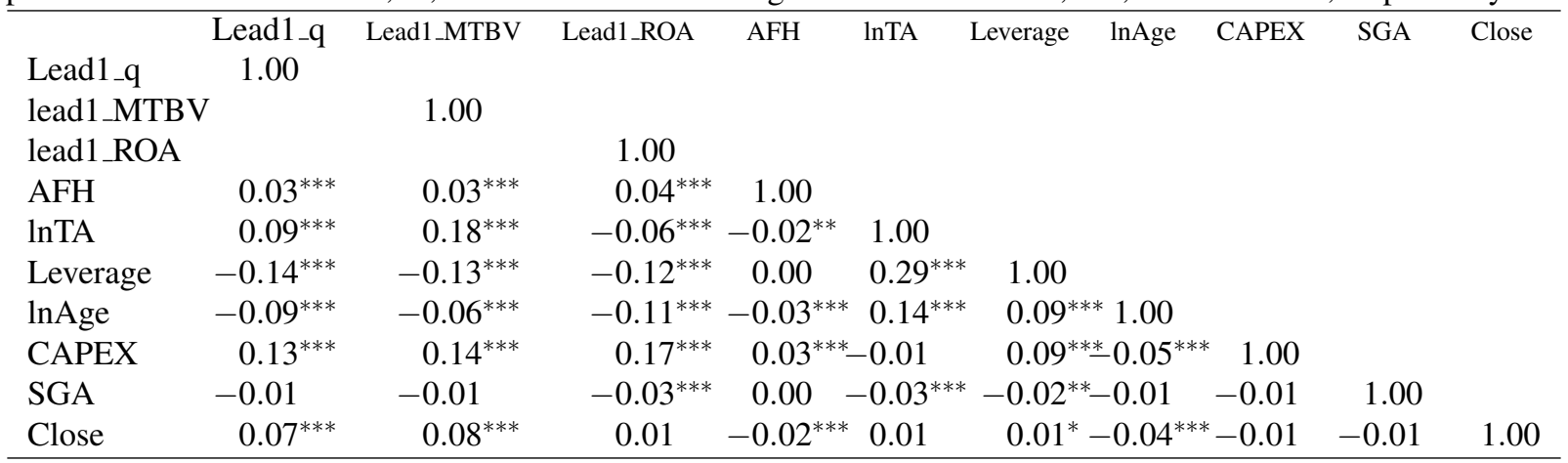

gression 4.2. As explained before, given $t$ as the current quarter, $t+k(\mathrm{k}=1,2 \ldots)$ indicates $k$ quarters ahead from $t$. For example, $q_{t+1}$ is firms' Tobin's q at one quarter ahead from $t$ (next quarter). I repeat Regression 4.2 from k equal to 1 onward, and focus on the coefficients on the $\operatorname{AFH}\left(\beta_{1}^{k}\right)$. The results are reported in Table 4.4.

Table 4.4 reports all the coefficients of Regression 4.2 with Tobin's q as the dependent variable, from $k=1$ to $k=5$. All the coefficients on the $A F H$ of $k=1$ to $k=4$ are positive and significant at the $1 \%$ level. For example, the coefficient on the AFH of $\mathrm{k}=1$ is 0.42 with the t-statistic of 3.18. The results prove a positive relationship between AFH and firms' future performance. This relationship exists until the next four quarters, suggesting that foreign investors are informed about firm performance in the next one year.

Moreover, although all coefficients on the $\mathrm{AFH}$ of $\mathrm{k}=(1,4)$ are positive and significant at the $1 \%$ level, they are decreasing from 0.42 at $\mathrm{k}=1$ to 0.22 at $\mathrm{k}=4$. This means that the informativeness of foreign investment is weaker overtime. Up to $\mathrm{k}=5$, the coefficient on the $\mathrm{AFH}$ is no longer statistically significant, suggesting that foreign investor ownership does not inform us of firm performance after one year.

For the robust results, I test the informativeness of the AFH using alternative variables of firm performance, MTBV and ROA. Table 4.5 reports the results for this test.

Table 4.5 reports all the coefficients of Regression 4.2 with MTBV and ROA as the dependent 
Panel A

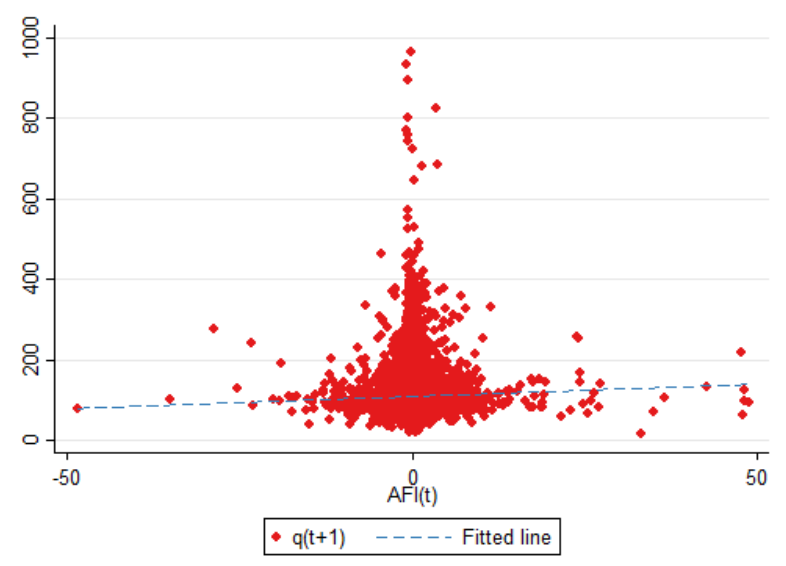

Panel B

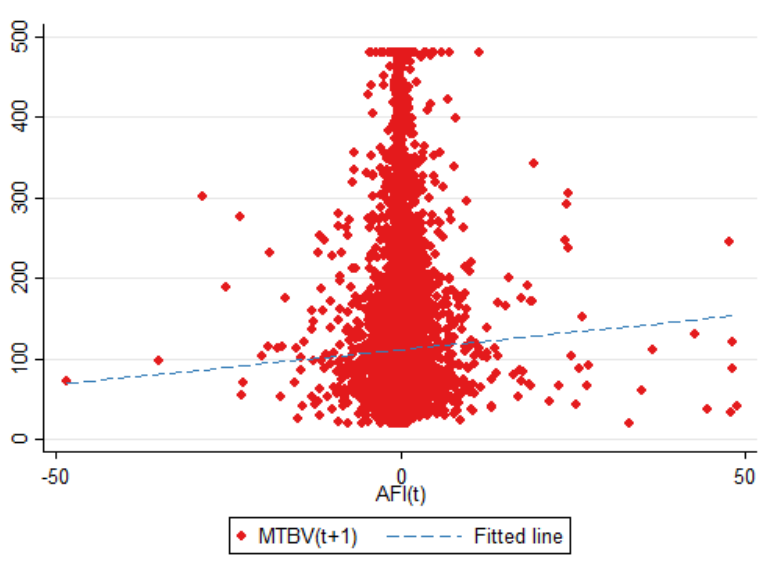

Panel C

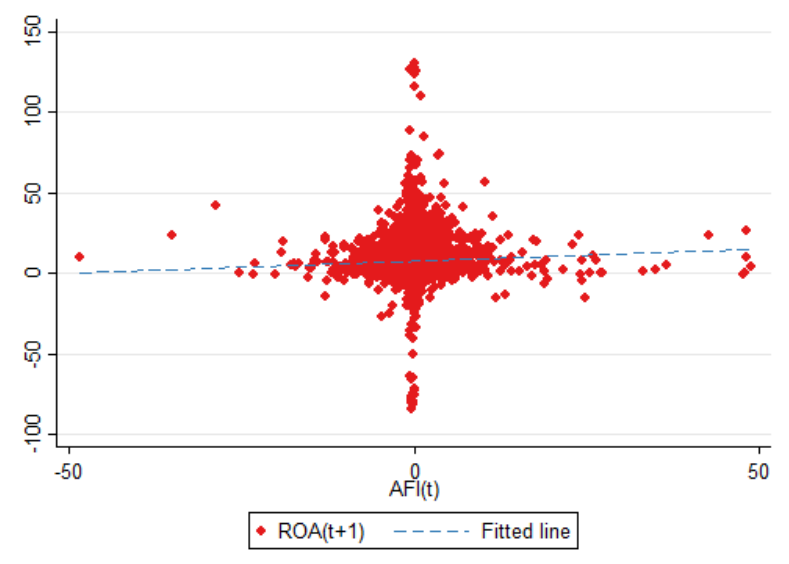

Figure 4.2. The plots of abnormal foreign investment versus firm performance

This figure plots the fitted lines of abnormal foreign investment (AFH) versus firm performance. Panel A, B, and C, respectively, present the fitted lines between the AFH current quarter and Tobin's q, MTBV, and ROA one quarter ahead. The variables are explained in Section 2.

variables, from $\mathrm{k}=1$ to $\mathrm{k}=5$. The first five columns of the table (left to right) report the results of the regression with MTBV as the dependent variable. Being consistent with the results in Table 4.4, the coefficients on the AFH of MTBV at $k=1$ to $k=4$ are positive and significant at the $5 \%$ or $1 \%$ level. For example, the coefficient on the AFH of the MTBV at $\mathrm{k}=4$ is 0.32 with a $t$-statistic of 2.03. Meanwhile, that coefficient at $\mathrm{k}=5$ is insignificant.

The last five columns of Table 4.5 report the results of Regression 4.2 with ROA as the dependent variable. I observe the same pattern of the informativeness of foreign investors as that in the first five columns of the same table, as well as in Table 4.4 .

In short, Tables 4.4 and 4.5 show that foreign investors are informed about firms' future per- 
Table 4.4. Informed foreign ownership and firm performance

This table reports the results of Regression 4.2 where Tobin's q is used as the proxy for the firm performance. $A F H$ is the abnormal foreign investment, estimated as the residuals from Regression 4.1. The other variables are explained in Section 2. The subscript $t$ indicates the current quarter. $t+k(\mathrm{k}=1,2 \ldots)$ is at $k$ quarters ahead from $t$. Standard errors are clustered at the firm-quarter level. $t$-statistics in the parentheses. ${ }^{*},{ }^{* *},{ }^{* *}$ indicate statistical significance at the $10 \%, 5 \%$, and $1 \%$ levels, respectively.

\begin{tabular}{|c|c|c|c|c|c|}
\hline \multicolumn{2}{|c|}{ Dependent variabe: $\mathrm{q}_{t+1}$} & $\mathrm{q}_{t+2}$ & $\mathrm{q}_{t+3}$ & $\mathrm{q}_{t+4}$ & $\mathrm{q}_{t+5}$ \\
\hline $\mathrm{AFH}_{t}$ & $\begin{array}{l}0.42^{* * *} \\
(3.18)\end{array}$ & $\begin{array}{l}0.29^{* * *} \\
(2.74)\end{array}$ & $\begin{array}{l}0.27^{* * *} \\
(2.84)\end{array}$ & $\begin{array}{l}0.22^{* * *} \\
(2.58)\end{array}$ & $\begin{array}{c}0.06 \\
(0.56)\end{array}$ \\
\hline $\operatorname{lnTA_{t}}$ & $\begin{array}{l}10.72^{* * * *} \\
(2.89)\end{array}$ & $\begin{array}{l}10.34^{* * *} \\
(2.79)\end{array}$ & $\begin{array}{l}9.48^{* * *} \\
(2.66)\end{array}$ & $\begin{array}{l}7.02^{* *} \\
(1.97)\end{array}$ & $\begin{array}{c}5.15 \\
(1.40)\end{array}$ \\
\hline Leverage $_{t}$ & $\begin{array}{l}-27.02^{* * *} \\
(-3.25)\end{array}$ & $\begin{array}{l}-28.15^{* * *} \\
(-3.48)\end{array}$ & $\begin{array}{l}-27.47^{* * *} \\
(-3.66)\end{array}$ & $\begin{array}{l}-23.88^{* * *} \\
(-3.28)\end{array}$ & $\begin{array}{l}-19.80^{* * *} \\
(-2.77)\end{array}$ \\
\hline $\ln \mathrm{Age}_{t}$ & $\begin{array}{l}-5.31^{* *} \\
(-2.17)\end{array}$ & $\begin{array}{r}-4.50^{*} \\
(-1.75)\end{array}$ & $\begin{array}{c}-3.32 \\
(-1.31)\end{array}$ & $\begin{array}{c}-2.51 \\
(-1.02)\end{array}$ & $\begin{array}{l}-1.45 \\
(-0.60)\end{array}$ \\
\hline CAPEX $_{t}$ & $\begin{array}{l}40.39^{* * *} \\
(4.01)\end{array}$ & $\begin{array}{l}37.77^{* * *} \\
(4.02)\end{array}$ & $\begin{array}{l}37.64^{* * *} \\
(3.81)\end{array}$ & $\begin{array}{l}28.64^{* * *} \\
(2.86)\end{array}$ & $\begin{array}{l}21.62^{* *} \\
(2.15)\end{array}$ \\
\hline $\mathrm{SGA}_{t}$ & $\begin{array}{c}0.01 \\
(0.69)\end{array}$ & $\begin{array}{c}0.00 \\
(0.28)\end{array}$ & $\begin{array}{c}-0.02 \\
(-1.53)\end{array}$ & $\begin{array}{l}-0.02^{* * *} \\
(-3.62)\end{array}$ & $\begin{array}{l}-0.02^{* * *} \\
(-3.20)\end{array}$ \\
\hline Close $_{t}$ & $\begin{array}{l}33.68^{* *} \\
(2.48)\end{array}$ & $\begin{array}{l}35.69^{* *} \\
(2.56)\end{array}$ & $\begin{array}{l}35.81^{* * *} \\
(2.59)\end{array}$ & $\begin{array}{l}30.11^{* *} \\
(2.15)\end{array}$ & $\begin{array}{l}29.17^{* *} \\
(2.06)\end{array}$ \\
\hline$\alpha_{t}$ & $\begin{array}{c}-92.83 \\
(-1.18)\end{array}$ & $\begin{array}{l}-57.55 \\
(-0.73)\end{array}$ & $\begin{array}{l}-69.37 \\
(-0.91)\end{array}$ & $\begin{array}{l}-10.23 \\
(-0.13)\end{array}$ & $\begin{array}{l}22.68 \\
(0.29)\end{array}$ \\
\hline Time and firm FE & yes & yes & yes & yes & yes \\
\hline$N$ & 13204 & 12559 & 11927 & 11458 & 10961 \\
\hline$R^{2}$ & 0.736 & 0.749 & 0.739 & 0.742 & 0.743 \\
\hline
\end{tabular}

formance in the shortterm (within one year).

\subsubsection{The subsample analysis}

In this section, I run Regression 4.2 again for different groups of firms constructed according to firm size, stock liquidity, firms with or without large foreign investors, and firms listed at HOSE or HNX, and then test whether the coefficients on the AFH of each group is significantly positive. For the groups of firm size, in each quarter I sort the sample firms into two groups depending on the median of firm total assets. The high- (low-) total-asset firms are then joined together across quarters to form large (small) groups of firms. Similarly, the more (less) liquid group of firms is created in the same logic as above, using the Amihud measure variable in the sorting exercise. Besides, firms with large foreign investors are firms whose shares are held by any large foreign investors (possessing 5\% of total firm shares or above) at any quarter during the sample period; 


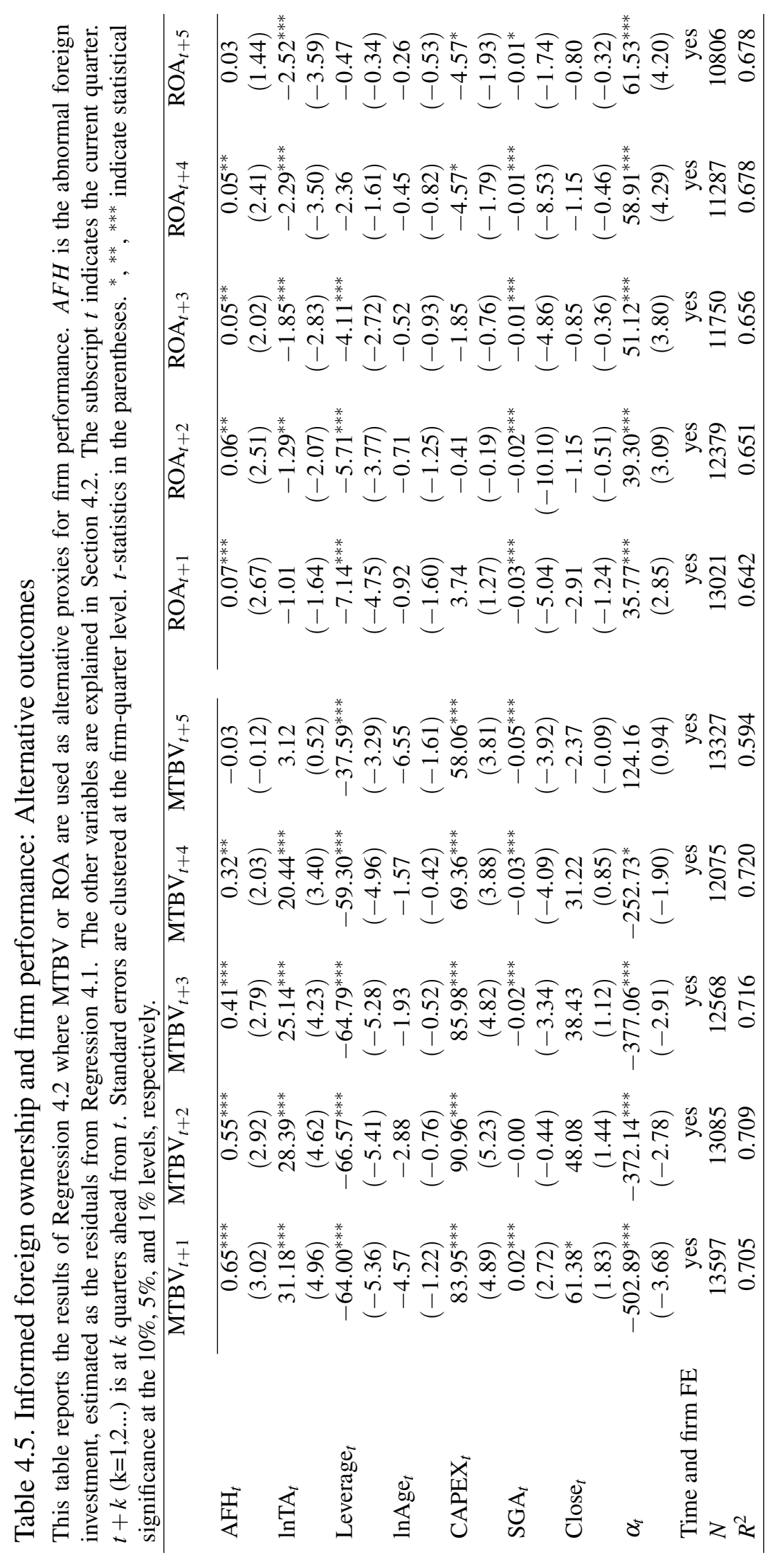


otherwise they are firms without large foreign investors. Finally, firms listed at HOSE (HNX) are firms registering their share codes at HOSE (HNX).

Table 4.6 reports the coefficients on the AFH of the groups of firms constructed above with Tobin's $\mathrm{q}$ as the dependent variable, from $\mathrm{k}=1$ to $\mathrm{k}=5$. With the same understanding as the previous tables, given $t$ at the current quarter, $t+k(\mathrm{k}=1,2 \ldots)$ indicates $k$ quarters ahead from $t$. Panel A of Table 4.6 reports the coefficients of firms with and without large foreign investors. Similarly, Panels B, C, and D of the table report the coefficient of groups of firms according to firm size (large and small firms), firm liquidity (more and less liquid firms), and firm location (firms listed at HOSE and HNX), respectively.

In Panel $\mathrm{A}$, while the coefficients on the $\mathrm{AFH}$ of $\mathrm{k}=(1,4)$ are significantly positive for firms having large foreign investors, only those of $\mathrm{k}=2$ and $\mathrm{k}=3$ are significantly positive for firms having no large foreign investors. The informativeness of the AFH thus is stronger for firms having large foreign investors. Similarly, the results in Panels B, C, and D show that the informativeness of the AFH is pronounced for large and liquid firms, and firms listed at HOSE, which is more active compared with HNX.

\subsection{Return profitability}

The results in the previous sections prove that foreign investors are informed about firms' performance in next four quarters. One question that may then arise is whether abnormal foreign investor holding predicts future stock returns. A study by Li, Nguyen, Pham, and Wei (2011) documents that large foreign ownership and stock return volatility are negatively correlated. And it is believed that foreign investors have powerful prediction ability about future stock prices. For example, Chang, Hsieh, and Lai (2009) find that the trades on options of foreign institutional investors have significant predictive power on the underlying asset returns. Another study conducted in the Vietnam stock market also concludes that foreign investors are positive feedback traders in the Vietnam stock market, when analyzing the foreign investors' trading volume and market 
Table 4.6. The subsample analysis

This table reports the subsample analysis for Equation (4.2). Firms with large foreign investors are firms whose shares are held by any large foreign investors (possessing from 5\% of total firm shares) at any quarter during the sample period; otherwise they are Firms without large foreign investors. Large (small) firms are firms in the first (second) half of the sample by firms' total assets at each quarter. High (less) liquid firms are firms in the first (second) half of the sample by firms' Amihud levels at each quarter. $A F H$ is abnormal foreign investment, estimated as the residuals from Regression 4.1. Controls are control variables used in Regression 4.2. The subscript $t$ indicates the current quarter. $t+k(\mathrm{k}=1,2 \ldots)$ is at $k$ quarters ahead from $t$. Standard errors are clustered at the firm-quarter level. $t$-statistics in the parentheses. ${ }^{*},{ }^{* *},{ }^{* * *}$ indicate statistical significance at the $10 \%, 5 \%$, and $1 \%$ levels, respectively.

\begin{tabular}{|c|c|c|c|c|c|c|c|c|c|c|}
\hline & $\mathrm{q}_{t+1}$ & $\mathrm{q}_{t+2}$ & $\mathrm{q}_{t+3}$ & $\mathrm{q}_{t+4}$ & $\mathrm{q}_{t+5}$ & $\mathrm{q}_{t+1}$ & $\mathrm{q}_{t+2}$ & $\mathrm{q}_{t+3}$ & $\mathrm{q}_{t+4}$ & $\mathrm{q}_{t+5}$ \\
\hline \multicolumn{6}{|c|}{ Panel A. With large foreign investors } & \multicolumn{5}{|c|}{ Firms without large foreign investors } \\
\hline $\mathrm{AFH}_{t}$ & $\begin{array}{r}0.56^{* * *} \\
(3.78)\end{array}$ & $\begin{array}{l}0.32^{* *} \\
(2.21)\end{array}$ & $\begin{array}{l}0.33^{* *} \\
(2.24)\end{array}$ & $\begin{array}{l}0.30^{* *} \\
(2.43)\end{array}$ & $\begin{array}{c}0.10 \\
(0.70)\end{array}$ & $\begin{array}{c}0.13 \\
(0.88)\end{array}$ & $\begin{array}{l}0.27^{* *} \\
(2.74)\end{array}$ & $\begin{array}{c}0.18^{* * *} \\
(3.72)\end{array}$ & $\begin{array}{c}0.07 \\
(0.96)\end{array}$ & $\begin{array}{c}-0.01 \\
(-0.05)\end{array}$ \\
\hline Controls $_{t}$ & yes & yes & yes & yes & yes & yes & yes & yes & yes & yes \\
\hline Time and firm FE & yes & yes & yes & yes & yes & yes & yes & yes & yes & yes \\
\hline$N$ & 6021 & 5762 & 5501 & 5302 & 5086 & 7183 & 6797 & 6426 & 6156 & 5875 \\
\hline$R^{2}$ & 0.683 & 0.682 & 0.689 & 0.694 & 0.697 & 0.784 & 0.808 & 0.789 & 0.790 & 0.790 \\
\hline
\end{tabular}

Panel B. Firm size

Large firms

\begin{tabular}{lcccccccccccc}
$\mathrm{AFH}_{t}$ & $0.58^{* * *}$ & $0.45^{* * *}$ & $0.32^{* *}$ & $0.30^{* *}$ & 0.13 & & 0.08 & -0.04 & 0.11 & 0.02 & -0.07 \\
& $(3.67)$ & $(2.77)$ & $(2.06)$ & $(2.03)$ & $(0.98)$ & & $(0.49)$ & $(-0.34)$ & $(1.13)$ & $(0.26)$ & $(-0.71)$ \\
& & & & & & & & & & & \\
Controls $t$ & yes & yes & yes & yes & yes & & yes & yes & yes & yes & yes \\
Time and firm FE & yes & yes & yes & yes & yes & & yes & yes & yes & yes & yes \\
$N$ & 6625 & 6335 & 6040 & 5810 & 5559 & & 6556 & 6199 & 5862 & 5622 & 5374 \\
$R^{2}$ & 0.718 & 0.722 & 0.724 & 0.726 & 0.726 & & 0.769 & 0.785 & 0.769 & 0.771 & 0.770 \\
\hline
\end{tabular}

Panel C. Firm liquidity

High liquid firms

\begin{tabular}{lccccccccccc}
$\mathrm{AFH}_{t}$ & $0.49^{* *}$ & $0.44^{* *}$ & 0.28 & 0.21 & 0.06 & & 0.13 & -0.22 & $0.22^{* *}$ & $0.22^{*}$ & 0.09 \\
& $(2.49)$ & $(2.48)$ & $(1.53)$ & $(1.02)$ & $(0.27)$ & & $(0.93)$ & $(-1.11)$ & $(2.03)$ & $(1.65)$ & $(0.60)$ \\
& & & & & & & & & & & \\
Controls & & & & & & & & & & & \\
Time and firm FE & yes & yes & yes & yes & yes & & yes & yes & yes & yes & yes \\
$N$ & 6558 & 6255 & 5956 & 5731 & 5492 & & 6576 & 6226 & 5897 & 5652 & 5396 \\
$R^{2}$ & 0.761 & 0.769 & 0.771 & 0.776 & 0.781 & & 0.780 & 0.794 & 0.769 & 0.767 & 0.758 \\
\hline
\end{tabular}

Panel D. Firm location

Firms listed at HOSE

\begin{tabular}{|c|c|c|c|c|c|c|c|c|c|c|}
\hline $\mathrm{AFH}_{t}$ & $\begin{array}{c}0.55^{* * *} \\
(2.95)\end{array}$ & $\begin{array}{l}0.44^{* *} \\
(2.24)\end{array}$ & $\begin{array}{c}0.29 \\
(1.59)\end{array}$ & $\begin{array}{c}0.29^{*} \\
(1.76)\end{array}$ & $\begin{array}{c}0.12 \\
(0.72)\end{array}$ & $\begin{array}{c}0.21 \\
(1.12)\end{array}$ & $\begin{array}{c}0.05 \\
(0.38)\end{array}$ & $\begin{array}{c}0.21^{* *} \\
(2.29)\end{array}$ & $\begin{array}{c}0.08 \\
(1.43)\end{array}$ & $\begin{array}{c}-0.06 \\
(-0.58)\end{array}$ \\
\hline Controls $_{t}$ & yes & yes & yes & yes & yes & yes & yes & yes & yes & yes \\
\hline Time and firm FE & yes & yes & yes & yes & yes & yes & yes & yes & yes & yes \\
\hline$N$ & 7188 & 6860 & 6526 & 6264 & 5965 & 6016 & 5699 & 5401 & 5194 & 4996 \\
\hline$R^{2}$ & 0.737 & 0.739 & 0.738 & 0.740 & 0.744 & 0.734 & 0.760 & 0.740 & 0.742 & 0.739 \\
\hline
\end{tabular}

returns of HOSE (Vo, 2017).

Therefore, it is worth testing whether foreign investment in the Vietnam stock market pre- 
dicts stock returns. Moreover, if abnormal foreign investor holding is correlated with future firm prices/returns, the changes in stock prices could be the profit for foreign investors.

To test whether abnormal foreign investment is related to future stock returns, I regress AFH on the stock returns using the equation below:

$$
\begin{aligned}
r_{i, t+k}=\alpha & +\gamma_{1}^{k} A F H_{i, t}+\gamma_{2}^{k} M T B V_{i t}+\gamma_{3}^{k} \ln M V_{i t}+\gamma_{4}^{k} \text { Amihud }_{i t}+\gamma_{5}^{k} \operatorname{lnsale~}_{i t} \\
& +\gamma_{6}^{k} D P S_{i t}+F_{i}+Q u t_{t}+\varepsilon_{i t}
\end{aligned}
$$

where $r$ is the quarterly average of daily stock returns, $\ln M V$ is the logarithm of the market value of equity, and lnsale is the logarithm of net sales. The other variables are explained in Section 2. $t$ indicates the current quarter, $\mathrm{k}=1,2, \ldots \mathrm{n}$. Firm fixed effects and quarter fixed effects are represented by $F_{i}$ and $Q u t_{t}$, respectively. Standard errors are clustered at the firm-quarter level.

Table 4.7 reports all coefficients of Regression (4.3) from $k=1$ to $k=4$. Similar to previous sections, $t+k(\mathrm{k}=1,2 \ldots)$ indicates $k$ quarters ahead from the current quarter $t$. I observe that the coefficients on the $\operatorname{AFH}\left(\gamma_{1}^{k}\right)$ at $\mathrm{k}=(1,3)$ are positive and statistically significant. For instance, the coefficient on the AFH at $\mathrm{k}=1, \gamma_{1}^{1}$, is 0.006 and significant at the $1 \%$ level, meaning that a $1 \%$ increase in the $\mathrm{AFH}$ current quarter is associated with a $0.6 \%$ increase in the daily stock return next quarter. The results are consistent with those of Ferreira et al. (2017), who find that the level of foreign institutional ownership predicts one-quarter-ahead stock returns. Further, I find the AFH holding predicts stock returns in three quarters ahead in this test.

However, many investors are much more concerned about returns than firm performance. Then the pretty low increase in daily stock return next quarter $(0.6 \%)$ per $1 \%$ increase in the AFH current quarter may suggest that foreign investors are not particularly informed about Vietnam companies. In fact, the minor interest implies that the foreign investors having more information about the global economy which could be relevant for Vietnamese firms who export. Dahlquist and Robertsson (2001) also conclude that firms' presence in international markets measured through export sales seems to characterize foreign holdings better than firm size alone. 
Table 4.7. Informed foreign ownership and stock prices

This table reports the coefficients for Equation (4.3). $r$ is the quarterly average of daily stock returns. $\ln M V$ is the logarithm of the market value of equity. Insale is the logarithm of the net sales. The other variables are explained in Section 4.2. The subscript $t$ indicates the current quarter. $t+k$ $(\mathrm{k}=1,2 \ldots)$ is at $k$ quarters ahead from $t$. Standard errors are clustered at the firm-quarter level. $t$-statistics in the parentheses, ${ }^{*},{ }^{* *},{ }^{* * *}$ indicate statistical significance at the $10 \%, 5 \%$, and $1 \%$ levels, respectively.

\begin{tabular}{lcccc}
\hline \multicolumn{1}{c}{ Dependent variable: } & $\mathrm{r}_{t+1}$ & $\mathrm{r}_{t+2}$ & $\mathrm{r}_{t+3}$ & $\mathrm{r}_{t+4}$ \\
& $0.006^{* * *}$ & $0.005^{* * *}$ & $0.003^{* *}$ & -0.001 \\
$\mathrm{AFH}_{t}$ & $(3.04)$ & $(3.02)$ & $(2.31)$ & $(-0.64)$ \\
& $0.083^{* * *}$ & 0.020 & $-0.056^{* *}$ & $-0.087^{* * *}$ \\
$\mathrm{MTBV}_{t}$ & $(3.08)$ & $(0.75)$ & $(-2.34)$ & $(-3.56)$ \\
& $0.080^{* * *}$ & $-0.062^{* * *}$ & $-0.191^{* * *}$ & $-0.294^{* * *}$ \\
$\operatorname{lnMV}_{t}$ & $(2.67)$ & $(-2.67)$ & $(-7.88)$ & $(-11.06)$ \\
& $-2.379^{* * *}$ & $-2.341^{* * *}$ & $-1.841^{* *}$ & -1.093 \\
Amihud $_{t}$ & $(-3.85)$ & $(-3.76)$ & $(-2.85)$ & $(-1.55)$ \\
& $0.038^{* * *}$ & $0.049^{* * *}$ & $0.061^{* * *}$ & $0.057^{* * *}$ \\
ln_sale $_{t}$ & $(3.81)$ & $(4.78)$ & $(6.36)$ & $(5.98)$ \\
& $-0.106^{* * *}$ & $-0.085^{* * *}$ & $-0.051^{* * *}$ & $-0.024^{*}$ \\
DPS $_{t}$ & $(-8.54)$ & $(-6.96)$ & $(-4.05)$ & $(-1.91)$ \\
& $-1.702^{* * *}$ & 0.463 & $1.883^{* * *}$ & $3.035^{* * *}$ \\
$\alpha_{t}$ & $(-4.10)$ & $(1.37)$ & $(5.81)$ & $(8.65)$ \\
& yes & yes & yes & yes \\
Time and firm FE $_{N}$ & 13161 & 12887 & 12607 & 12122 \\
$R^{2}$ & 0.432 & 0.432 & 0.473 & 0.533 \\
\hline
\end{tabular}

\subsection{Changes of foreign ownership and firm performance}

When giving explanations for the positive relationship between institutional ownership and returns, Gompers and Metrick (2001) argue that the change of institutional ownership from the last period to the current period $\left(\triangle I O_{t}\right)$ forecasts returns better than the last period's level of institutional ownership $\left(I O_{t-1}\right)$ if the relationship between institutional ownership and returns is driven by an information or smart-institutions explanation. In contrast, if the relationship is driven by the demand shock, $I O_{t-1}$ is a better predictor of future institutional demand.

Following the literature, I also use $\triangle F O$ as a measure of new information obtained by foreign investors. The advantage of using $\triangle F O$ over $\mathrm{AFH}$ is that it is model free and thus does not have statistical issues. Then, if foreign investors are informed about firm performance, I expect that the changes of foreign ownership from the last period to the current period ( $\triangle F O_{t}$ ) is positively correlated with firms' future performance. 
In this section, I conduct a robustness test on the relationship between foreign investment and firms' future performance, using $\triangle \mathrm{FO}$ as another proxy for the information obtained by foreign investors. $\triangle \mathrm{FO}$ is the first difference of the FO variable. This new variable is used as the independent variable in the equation below:

$$
\begin{aligned}
\text { performance }_{i, t+k}=\alpha & +\delta_{1}^{k} \triangle F O_{i, t}+\delta_{2}^{k} \ln T A_{i t}+\delta_{3}^{k} \text { Leverage }_{i t}+\delta_{4}^{k} F T S E_{i t}+\delta_{5}^{k} \text { Cash }_{i t} \\
& +\delta_{6}^{k} C A P E X_{i t}+\delta_{7}^{k} S G A_{i t}+\delta_{8}^{k} \operatorname{lnAge_{it}}+\delta_{9}^{k} \text { Close }_{i t}+\text { Qut }_{t}+\varepsilon_{i t}
\end{aligned}
$$

where performance is one of the three firm performance variables: Tobin's q, MTBV, or ROA. performance $_{t+k}$ represents the firm performance variable at $k$ quarter ahead. Given $t$ as the current quarter, then $k=1,2, . . n$. $\triangle \mathrm{FO}$ is the first difference of the $\mathrm{FO}$ variable. The other variables are explained in Section 4.2. Firm fixed effects are not required, since the first difference of the independent variable is used. Yet time fixed effects are added, and standard errors are clustered at the firm-quarter level.

Table 4.8 reports all the coefficients of Regression 4.4. To be aligned with the main regression in Table 4.4, I report the results of Regression 4.4 from $k=1$ to $k=5$ in Table 4.8. The first five columns (left to right) show the coefficients of Regression 4.4 with Tobin's q as the dependent variable. Similarly, the middle and the last five columns show the coefficients of Regression 4.4 with MTBV and ROA, respectively, as the dependent variables.

I observe that the $\triangle F O$ positively correlates with Tobin's q up to two quarters ahead. Specifically, the coefficients on $\triangle \mathrm{FO}$ at $\mathrm{k}=1$ and $\mathrm{k}=2$ for Tobin's $\mathrm{q}$ are 0.46 and 0.33 and significant at the $5 \%$ and $10 \%$ levels, respectively, but the coefficient at $\mathrm{k}=3$ is 0.25 and not statistically significant. For the regressions using MTBV, the coefficient on $\triangle F O$ is positively significant at $\mathrm{k}=1,2$, and 3. For the regressions of ROA, except at $\mathrm{k}=4$, the coefficients of other quarters are positively significant at the $5 \%$ or $10 \%$ level.

Although the results are a little weaker than those of Equation (4.2), they generally prove that foreign investors have information about firms' future performance when trading the stocks. This finding is consistent with what I find in the previous tests. 


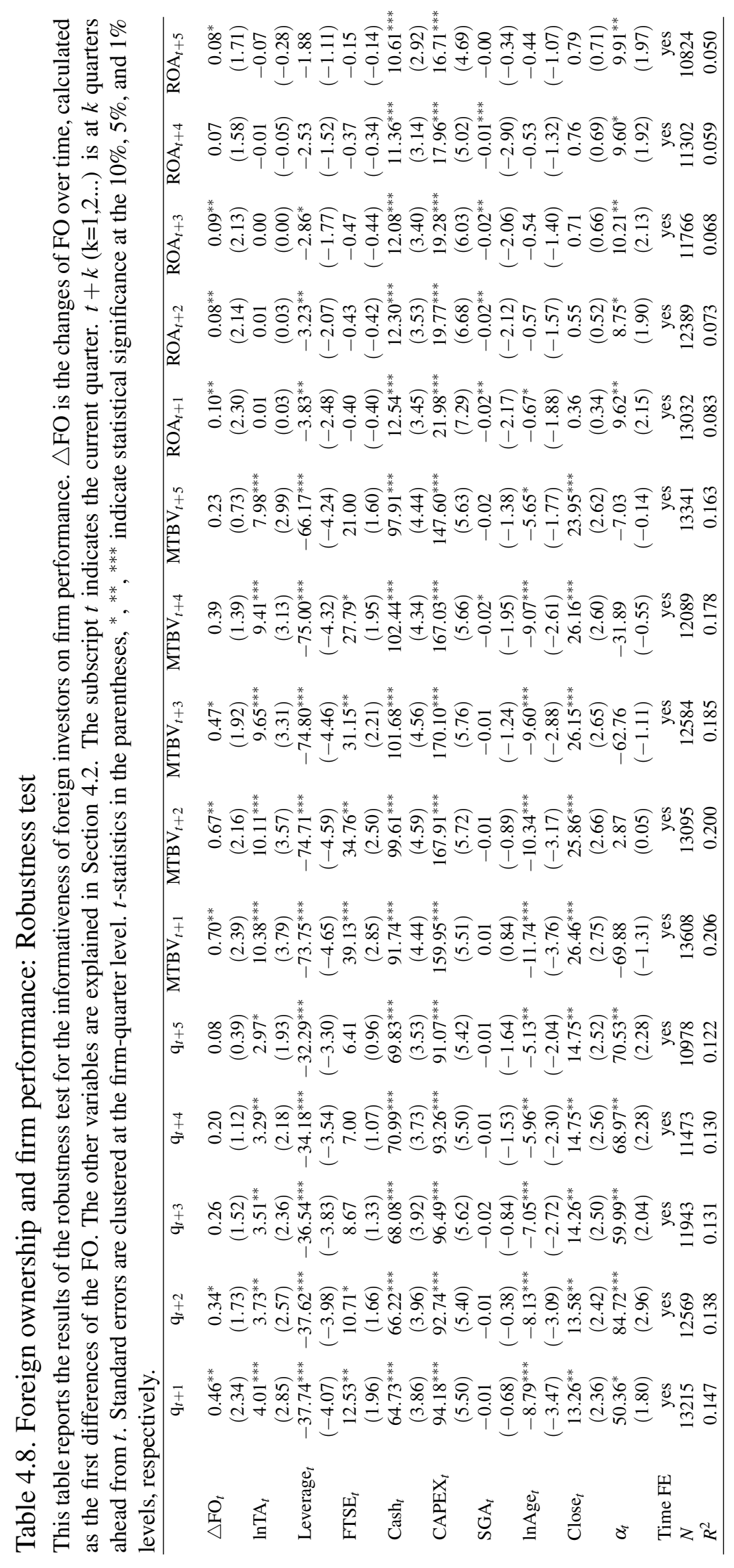




\subsection{Conclusion}

One question of interest in finance research is what information foreign investors may learn about firms. Are they informed about firm performance which presents the fundamental value of firms? To address this question, I use the residuals of a foreign investment regression - defined as the abnormal foreign investor holding - to measure the information obtained by foreign investors, and regress this abnormal foreign investor holding on firms' future performance as well as the control variables.

I find that the foreign investors in the Vietnam stock market are informed about firm performance in the next four quarters. The abnormal foreign investor holding is positively correlated with firms' future performance. In other words, a higher abnormal foreign investor holding at the current time is associated with a higher level of the firm performance measures at the next four quarters. This positive relationship is robust even after using different measures of firm performance and a different proxy for the new information of foreign investors.

In the sub-sample analysis, I find that the informativeness of foreign investors is pronounced for large and liquid firms, firms having large foreign investors, and firms listed at HOSE.

Moreover, the abnormal foreign investor holding at the current time is also positively correlated with the stock returns at the next three quarters. Therefore, foreign investors are informed not only about firm performance, such informativeness also generates economic profit. This finding suggests that the abnormal foreign ownership in the Vietnam stock market is informed about firms up to a one-year period. 
Appendices 


\section{Appendix 1}

Table D.1. Corporate governance scorecard

This table presents all questions on the CG scorecard in detail. The CG scorecard has five sections, as explained in Section 3.2.2.

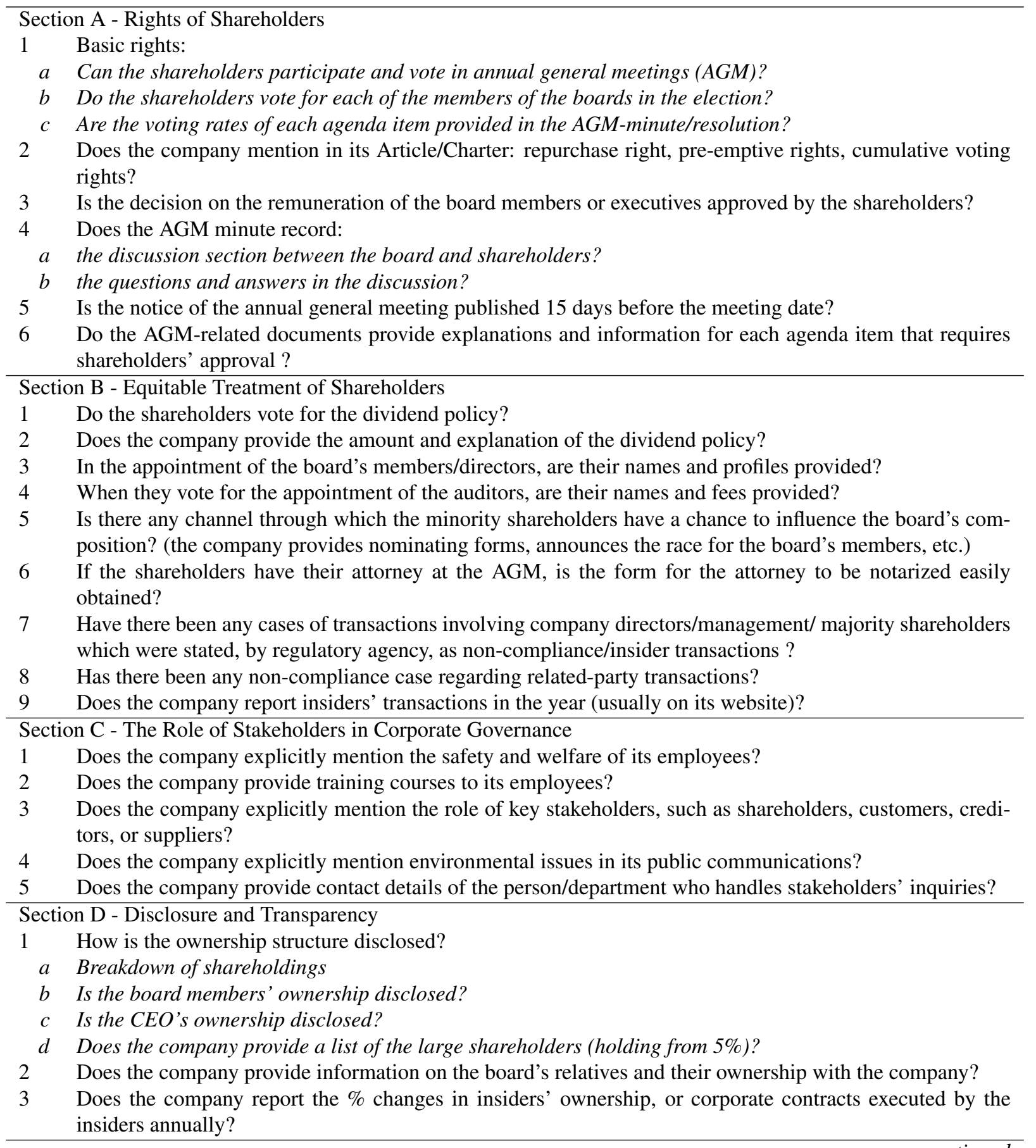


continued

4 Is the remuneration of the board members or executives specifically provided?

5 Is the following information accessible from annual reports?

a Business operations

$b$ The corporate orientation

c Organization structure

$d$ Board members' profiles with their directorships in other public companies/franchises, etc.

e Basis of the board remuneration

$f$ Business plan for next year(s)

$g \quad$ Risk management

$h$ Financial performance, providing common financial ratios: ROS. ROE, EPS, etc.

6 Does the company have an internal audit operation

a Is it established as a separate unit in the company?

$b$ To whom does the internal audit function report?

7 Does the company perform an annual audit using independent and reputable auditors?

8 Have the board approved the performance of the financial statement?

9 Does the company have a website, disclosing up-to-date information?

a Business operations

b Organization structure

c The board structure

$d$ Are the following documents downloadable? - Annual report, quarterly reports, audited financial statements, company's articles, AGM-related documents, and regular/non-regular public information

$e \quad$ Are the above documents provided in both Vietnamese and English?

Section E - Responsibility of the Board

1 Does the company have a corporate vision/mission?

2 Is there any innovation in the company's vision/mission each year? (Does the board review the vission/mission each year?)

3 Does the company have an internal corporate governance policy?

4 Does the board of directors provide a code of ethics or statement of business conduct for all directors and employees?

$5 \quad$ Have the board members attended management courses, or does the company provide courses for directors?

6 Does the company provide internal corporate governance rules? (AGM's rules, voting rules, nominating rules, rules for compensation, etc.)

$7 \quad$ How many board meetings are held per year?

8 Do the board members fully attend the board meetings (at least $75 \%$ of total board meetings)?

9 In the AGM:

a Did the chairman of the board attend?

$b \quad$ Did the CEO/managing director attend?

10 Are the following compliant with law*?

a The size of the board (5-11 members)

$b \quad$ At least $1 / 3$ of the board members are independent

c At least 1/3 of the board members are non-executive

$d$ Is the chairman also the CEO?

11 Has the regulatory agency reminded/fined the company due to its non-compliance with rules and regulations to the extent of governance, or for being late in providing public information this year?

\footnotetext{
*According to Corporate Law number 68/2014/QH13 of Vietnam
} 


\section{Appendix 2}

\section{Table D.2. Data collection}

This table presents all sample data collected from alternative databases. The definition is retrieved directly from the databases.

\begin{tabular}{|c|c|c|}
\hline Data & Database & Definition/Describe \\
\hline Intraday information & TRTH & Tick by tick (Thomson SIRCA) \\
\hline Foreign ownership & $\begin{array}{l}\text { Private data } \\
\text { company }\end{array}$ & The percentages of foreign shareholding to a company \\
\hline Large shareholding & $\begin{array}{l}\text { Private data } \\
\text { company }\end{array}$ & The ownership percentages of large shareholders in a company \\
\hline Firm annual reports & Firm websites & \\
\hline SGM related documents & Firm websites & $\begin{array}{l}\text { Documents used for Shareholder general meeting, e.g. minutes, proposals, } \\
\text { etc. }\end{array}$ \\
\hline $\begin{array}{l}\text { Documents relating to } \\
\text { recording CGS }\end{array}$ & $\begin{array}{l}\text { Firm and SSC } \\
\text { websites }\end{array}$ & $\begin{array}{l}\text { Firms acticles, notices from the SSC (Vietnam) of firms' violations on the } \\
\text { securities market, etc }\end{array}$ \\
\hline Financial policies & \multicolumn{2}{|c|}{ The financial policy database, The Ministry of Finance (Vietnam) } \\
\hline Market capitalization & Bloomberg & $\begin{array}{l}\text { This is a company's worth as indicated by the price of its issued and out- } \\
\text { standing stock shares }\end{array}$ \\
\hline Outstanding shares & Bloomberg & $\begin{array}{l}\text { A company's shares outstanding are reported in its quarterly and annual } \\
\text { balance sheet }\end{array}$ \\
\hline $\mathrm{PE}$ ratio & Bloomberge & $\begin{array}{l}\text { Price-to-earnings ratio is calculated by diving the stock price of the com- } \\
\text { pany with its earnings per share. }\end{array}$ \\
\hline Book value of equity & WC03501 & $\begin{array}{l}\text { Common equity represents common shareholders' investment in a com- } \\
\text { pany. }\end{array}$ \\
\hline Capital expenditure & WC04601 & $\begin{array}{l}\text { Capital expenditure represents the funds used to acquire fixed assets other } \\
\text { than those associated with acquisitions. }\end{array}$ \\
\hline Closely held share & WC05474 & $\begin{array}{l}\text { Closely held share (current) represents shares held by insiders. For com- } \\
\text { panies with more than one class of common stock, closely held shares for } \\
\text { each class is added together. }\end{array}$ \\
\hline Net sales/revenues & WC01001A & $\begin{array}{l}\text { Net sales or revenues represent gross sales and other operating revenue less } \\
\text { discounts, returns and allowances. Interim data. }\end{array}$ \\
\hline Operating income & WC01250 & $\begin{array}{l}\text { Operating income represents the difference between sales and total operat- } \\
\text { ing expenses }\end{array}$ \\
\hline $\begin{array}{l}\text { Selling and general } \\
\text { administrative expenses }\end{array}$ & WC01101A & $\begin{array}{l}\text { Selling and general administrative expenses represents expenses not di- } \\
\text { rectly attributable to the production process but relating to selling, general } \\
\text { and administrative functions. Interim data. }\end{array}$ \\
\hline Share outstanding & WC05301 & It represents the number of shares outstanding at the company's year end. \\
\hline Total assets & WC02999A & Interim time series of total assets \\
\hline Total debts & WC03255A & Interim time series of total debts \\
\hline Adjusted close price & Datastream & $\begin{array}{l}\text { The official closing price. These stored prices are adjusted for subsequent } \\
\text { capital actions. }\end{array}$ \\
\hline Daily volume & Datastream & The number of shares traded for a stock on a particular day. \\
\hline Dividends per share & Datastream & Rolling 12 month dividends per share (adjusted) \\
\hline Market value of equity & Datastream & The share price multiplied by the number of ordinary shares in issue. \\
\hline Market to book value & Datastream & $\begin{array}{l}\text { Defined as the market value of the ordinary (common) equity divided by } \\
\text { the balance sheet value of the ordinary (common) equity in the company }\end{array}$ \\
\hline Risk free rate & Datastream & One-year government bond yield \\
\hline PE ratio & Datastream & Price divided by the earnings rate per share at the required date. \\
\hline
\end{tabular}




\section{References}

Abad-Diaz, D., Yagüe, J., 2012. From PIN to VPIN: An introduction to order flow toxicity. The Spanish Review of Financial Economics 10, 74-83.

Acharya, V. V., Johnson, T. C., 2007. Insider trading in credit derivatives. Journal of Financial Economics 84, 110-141.

Aghanya, D., Agarwal, V., Poshakwale, S., 2020. Market in financial instruments directive (MiFID), stock price informativeness and liquidity. Journal of Banking \& Finance, forthcoming .

Ahern, K. R., 2017. Information networks: Evidence from illegal insider trading tips. Journal of Financial Economics 125, 26-47.

Aitken, M., Cumming, D., Zhan, F., 2015. Exchange trading rules, surveillance and suspected insider trading. Journal of Corporate Finance 34, 311-330.

Ali, S., Liu, B., Su, J. J., 2017. Corporate governance and stock liquidity dimensions: Panel evidence from pure order-driven Australian market. International Review of Economics and Finance $50,275-304$.

Amihud, Y., 2002. Illiquidity and stock returns: Cross-section and time-series effects. Journal of Financial Markets 5, 31-56.

Andersen, T. G., Bondarenko, O., 2014. VPIN and the flash crash. Journal of Financial Markets $17,1-46$.

Anderson, R. C., Reeb, D. M., Zhao, W., 2012. Family-controlled firms and informed trading: Evidence from short sales. The Journal of Finance 67, 351-385. 
Asian Development Bank, 2013. ASEAN Corporate Governance Scorecard: Country Reports and Assessments 2012-2013. Asian Development Bank. http://hdl.handle.net/11540/833. .

Aslan, H., Easley, D., Hvidkjaer, S., O’Hara, M., 2011. The characteristics of informed trading: Implications for asset pricing. Journal of Empirical Finance 18, 782-801.

Bae, K.-H., Stulz, R. M., Tan, H., 2008. Do local analysts know more? A cross-country study of the performance of local analysts and foreign analysts. Journal of Financial Economics 88, 581 $-606$.

Baik, B., Kang, J.-K., Kim, J.-M., 2010. Local institutional investors, information asymmetries, and equity returns. Journal of Financial Economics 97, 81 - 106.

Bailey, W., Mao, C. X., Sirodom, K., 2007. Investment restrictions and the cross-border flow of information: Some empirical evidence. Journal of International Money and Finance 26, 1 - 25.

Becker, G. S., 1983. A theory of competition among pressure groups for political influence. The Quarterly Journal of Economics 98, 371-400.

Bena, J., Ferreira, M. A., Matos, P., Pires, P., 2017. Are foreign investors locusts? The long-term effects of foreign institutional ownership. Journal of Financial Economics 126, 122 - 146.

Bergman, N. K., Nicolaievsky, D., 2007. Investor protection and the Coasian view. Journal of Financial Economics 84, $738-771$.

Bernile, G., Bhagwat, V., Yonker, S., 2018. Board diversity, firm risk, and corporate policies. Journal of Financial Economics 127, 588 - 612.

Bhattacharya, U., Daouk, H., 2002. The world price of insider trading. The Journal of Finance 57, 75-108.

Bhattacharya, U., Daouk, H., 2009. When no law is better than a good law. Review of Finance 13, $577-627$.

Bhattacharya, U., Daouk, H., Jorgenson, B., Kehr, C.-H., 2000. When an event is not an event: The curious case of an emerging market. Journal of Financial Economics 55, 69-101. 
Bhattacharya, U., Spiegel, M., 1991. Insiders, outsiders, and market breakdowns. The Review of Financial Studies 4, 255-282.

Brown, L. D., Caylor, M. L., 2006. Corporate governance and firm valuation. Journal of Accounting and Public Policy 25.

Budsaratragoon, P., Hillier, D., Lhaopadchan, S., 2012. Applying developed-country regulation in emerging markets: an analysis of thai insider trading. Accounting \& Finance 52, 1013-1039.

Bushman, R. M., Piotroski, J. D., Smith, A. J., 2005. Insider trading restrictions and analysts' incentives to follow firms. The Journal of Finance 60, 35-66.

Campbell, J. Y., Lo, A. W., MacKinlay, A. C., 1997. The Econometrics of Financial Markets. Princeton University Press, Princeton, NJ.

Campos, C.E., N. R., Wilson, G., 2002. Corporate governance develops in emerging markets. McKinsey on Finance pp. 15-18.

Chang, C.-C., Hsieh, P.-F., Lai, H.-N., 2009. Do informed option investors predict stock returns? Evidence from the Taiwan stock exchange. Journal of Banking \& Finance 33, 757 - 764.

Chang, H.-L., Su, C.-W., 2010. The relationship between the Vietnam stock market and its major trading partners - TECM with bivariate asymmetric GARCH model. Applied Economics Letters $17,1279-1283$.

Chen, Z., Huang, Y., Kusnadi, Y., Wei, K. J., 2017. The real effect of the initial enforcement of insider trading laws. Journal of Corporate Finance 45, 687-709.

Cheuk, M.-Y., Fan, D. K., So, R. W., 2006. Insider trading in Hong Kong: Some stylized facts. Pacific-Basin Finance Journal 14, 73-90.

Choe, H., Kho, B.-C., Stulz, R. M., 1999. Do foreign investors destabilize stock markets? The Korean experience in 1997. Journal of Financial Economics 54, 227 - 264.

Chordia, T., Roll, R., Subrahmanyam, A., 2008. Liquidity and market efficiency. Journal of Financial Economics 87, 249-268. 
Christensen, H. B., Hail, L., Leuz, C., 2016. Capital-market effects of securities regulation: Prior conditions, implementation, and enforcement. The Review of Financial Studies 29, 2885-2924.

Chung, D. Y., Hrazdil, K., 2010. Liquidity and market efficiency: Analysis of NASDAQ firms. Global Finance Journal 21, $262-274$.

Chung, K. H., Chuwonganant, C., 2012. Regulation NMS and market quality. Financial Management 41, 285-317.

Comerton-Forde, C., Rydge, J., 2006. Market integrity and surveillance effort. Journal of Financial Services Research 29, 149-172.

Coval, J. D., Moskowitz, T. J., 2001. The geography of investment: Informed trading and asset prices. Journal of Political Economy 109, 811-841.

Cumming, D., Dannhauser, R., Johan, S., 2015. Financial market misconduct and agency conflicts: A synthesis and future directions. Journal of Corporate Finance 34, 150-168.

Cumming, D., Johan, S., 2008. Global market surveillance. American Law and Economics Review 10, 454-506.

Cumming, D., Johan, S., Li, D., 2011. Exchange trading rules and stock market liquidity. Journal of Financial Economics 99, 651-671.

Cunat, V., Gine, M., Guadalupe, M., 2012. The vote is cast: The effect of corporate governance on shareholder value. The Journal of Finance 67, 1943-1977.

Dahlquist, M., Robertsson, G., 2001. Direct foreign ownership, institutional investors, and firm characteristics. Journal of Financial Economics 59, 413-440.

Dai, L., Fu, R., Kang, J.-K., Lee, I., 2016. Corporate governance and the profitability of insider trading. Journal of Corporate Finance 40, 235 - 253.

Djankov, S., Glaeser, E., La Porta, R., Lopez-de Silanes, F., Shleifer, A., 2003. The new comparative economics. Journal of Comparative Economics 31, 595-619. 
Doidge, C., Karolyi, G. A., Stulz, R. M., 2007. Why do countries matter so much for corporate governance? Journal of Financial Economics 86, 1 - 39.

Domowitz, I., 2012. Market abuse and surveillance. Working paper, Government Office for Science, London .

Durnev, A., Kim, E., 2005. To steal or not to steal: Firm attributes, legal environment, and valuation. The Journal of Finance 60, 1461-1493.

Dyck, A., Lins, K. V., Roth, L., Wagner, H. F., 2019. Do institutional investors drive corporate social responsibility? International evidence. Journal of Financial Economics 131, 693 - 714.

Easley, D., Kiefer, N. M., O’Hara, M., Paperman, J. B., 1996. Liquidity, information, and infrequently traded stocks. The Journal of Finance 51, 1405-1436.

Easley, D., López de Prado, M. M., O’Hara, M., 2012. Flow Toxicity and Liquidity in a Highfrequency World. The Review of Financial Studies 25, 1457-1493.

Easley, D., O’hara, M., 1987. Price, trade size, and information in securities markets. Journal of Financial economics 19, 69-90.

Easley, D., O'hara, M., 2004. Information and the cost of capital. The Journal of Finance 59, $1553-1583$.

Fama, E. F., French, K. R., 1993. Common risk factors in the returns on stocks and bonds. Journal of Financial Economics 33, 3 - 56.

Farber, A., Vuong, Q.-H., 2004. New empirical results on anomalies and herd behavior: Vietnam stock market 2000-2004. Economic Studies 44, 55-59.

Fauver, L., Hung, M., Li, X., Taboada, A. G., 2017. Board reforms and firm value: Worldwide evidence. Journal of Financial Economics 125, 120 - 142.

Fernandes, N., Ferreira, M. A., 2009. Insider trading laws and stock price informativeness. The Review of Financial Studies 22, 1845-1887. 
Ferreira, M. A., Matos, P., 2008. The colors of investors' money: The role of institutional investors around the world. Journal of Financial Economics 88, 499 - 533.

Ferreira, M. A., Matos, P., Pereira, J. P., Pires, P., 2017. Do locals know better? A comparison of the performance of local and foreign institutional investors. Journal of Banking \& Finance 82, $151-164$.

Fich, E. M., Shivdasani, A., 2006. Are busy boards effective monitors? The Journal of Finance 61, $689-724$.

Flannery, M. J., Hankins, K. W., 2013. Estimating dynamic panel models in corporate finance. Journal of Corporate Finance 19, 1 - 19.

Fox, M. B., Glosten, L. R., Rauterberg, G. V., 2018. Informed trading and its regulation. Journal of Corporation Law 43, 817-98.

Frijns, B., Gilbert, A., Tourani-Rad, A., 2008. Insider trading, regulation, and the components of the bid-ask spread. Journal of Financial Research 31, 225-246.

Frijns, B., Gilbert, A., Tourani-Rad, A., 2013. Do criminal sanctions deter insider trading? Financial Review 48, 205-232.

Froot, K. A., O'Connell, P. G., Seasholes, M. S., 2001. The portfolio flows of international investors. Journal of Financial Economics 59, 151 - 193.

Gompers, P., Ishii, J., Metrick, A., 2003. Corporate governance and equity prices. The Quarterly Journal of Economics 118, 107-156.

Gompers, P. A., Metrick, A., 2001. Institutional investors and equity prices. The Quarterly Journal of Economics 116, 229-259.

Gul, F. A., Kim, J.-B., Qiu, A. A., 2010. Ownership concentration, foreign shareholding, audit quality, and stock price synchronicity: Evidence from China. Journal of Financial Economics $95,425-442$.

He, Y., Lin, H., Wang, J., Wu, C., 2009a. Price discovery in the round-the-clock US Treasury market. Journal of Financial Intermediation 18, 464-490. 
He, Y., Lin, H., Wu, C., Dufrene, U. B., 2009b. The 2000 presidential election and the information cost of sensitive versus non-sensitive S\&P 500 stocks. Journal of Financial Markets 12, 54-86.

Kang, J.-K., Stulz, R., 1997. Why is there a home bias? An analysis of foreign portfolio equity ownership in Japan. Journal of Financial Economics 46, 3 - 28.

Karmani, M., Ajina, A., 2012. Market stock liquidity and corporate governance. 29th International Conference of the French Finance Association (AFFI) 2012. https://ssrn.com/abstract=2084707 or http://dx.doi.org/10.2139/ssrn.2084707 .

Khanchel, I., 2007. Corporate governance: measurement and determinant analysis. Managerial Auditing Journal 22, 740-760.

Klapper, L. F., Love, I., 2004. Corporate governance, investor protection, and performance in emerging markets. Journal of Corporate Finance 10, 703-728.

Kyle, A. S., 1985. Continuous auctions and insider trading. Econometrica 53, 1315-1335.

Lee, C. M., Ready, M. J., 1991. Inferring trade direction from intraday data. The Journal of Finance $46,733-746$.

Lesmond, D. A., 2005. Liquidity of emerging markets. Journal of Financial Economics 77, 411452.

Li, D., Nguyen, Q. N., Pham, P. K., Wei, S. X., 2011. Large foreign ownership and firm-level stock return volatility in emerging markets. The Journal of Financial and Quantitative Analysis 46, $1127-1155$.

Loc, T., Lanjouw, G., Lensink, R., 2010. Stock-market efficiency in thin-trading markets: The case of the Vietnamese stock market. Applied Economics 42, 3519-3532.

Madhani, P. M., 2016. The impact of legal and regulatory environment: A study of corporate governance and disclosure practice of firms listed on Bombay stock exchange. IUP Journal of Corporate Governance 15, 7-36.

Madhavan, A., Richardson, M., Roomans, M., 1997. Why do security prices change? A transaction-level analysis of NYSE stocks. The Review of Financial Studies 10, 1035-1064. 
Malloy, C. J., 2005. The geography of equity analysis. The Journal of Finance 60, 719-755.

Mathew, S., Ibrahim, S., Archbold, S., 2018. Corporate governance and firm risk. Corporate Governance $18,52-67$.

Meulbroek, L. K., 1992. An empirical analysis of illegal insider trading. The Journal of Finance 47, 1661-1699.

Newey, W. K., West, K. D., 1987. A simple, positive semi-definite, heteroskedasticity and autocorrelation consistent covariance matrix. Econometrica 55, 703-708.

OECD, 2015. G20/OECD Principles of Corporate Governance. OECD Publishing, Paris. http://dx.doi.org/10.1787/9789264236882-en .

Ojah, K., Muhanji, S., Kodongo, O., 2020. Insider trading laws and price informativeness in emerging stock markets: The South African case. Emerging Markets Review, forthcoming .

Palan, S., Stöckl, T., 2017. When chasing the offender hurts the victim: The case of insider legislation. Journal of Financial Markets 35, 104-129.

Pástor, L., Stambaugh, R. F., 2003. Liquidity risk and expected stock returns. Journal of Political economy $111,642-685$.

Porta, R. L., de Silanes, F. L., Shleifer, A., Vishny, R., 2000. Investor protection and corporate governance. Journal of Financial Economics 58, 3 - 27.

Posner, R. A., 1974. Theories of economic regulation. The Bell Journal of Economics \& Management Science 5, 335-358.

Stigler, G. J., 1971. The theory of economic regulation. The Bell Journal of Economics \& Management Science 2, 3-21.

Vo, X. V., 2017. Trading of foreign investors and stock returns in an emerging market - Evidence from Vietnam. International Review of Financial Analysis 52, 88 - 93.

Wong, W. K., Tan, D., Tian, Y., 2009. Informed trading and liquidity in the Shanghai stock exchange. International Review of Financial Analysis 18, $66-73$. 